\title{
A CRYSTALLOGRAPHIC STUDY OF THE DATOLITE FROM WESTFIELD, MASSACHUSETTS.
}

\author{
By Earl V. Shannon,
}

Assistant Curator, Department of Geology, United States National Museum.

\section{INTRODUCTION.}

The locality of Westfield, Massachusetts, has within the past 18 years produced datolite crystals in such abundance and of such unusual size and perfection of form that the specimens have become well known and are now widely distributed in mineralogical collections. The datolite of this occurrence was first described by Whitlock, ${ }^{1}$ whose work apparently was based on only a few crystals. Upon these 27 forms were found, four of which were new. Immediately following the publication of Whitlock's paper, Kraus and $\mathrm{Cook}^{2}$ published a more extensive study of this datolite, their collection consisting of some 45 crystals, of which 10 were measured in detail. They added three new forms to the list and found a number of previously known forms not present on the crystals examined by Whitlock. Later Görgey and Goldschmidt, ${ }^{3}$ in a general study of datolite, examined 11 crystals from Westfield, upon which they found eight new forms; and later still Ungemach ${ }^{4}$ has reviewed all previous work on the mineral from this locality and measured eight crystals on which nine additional new forms were found. Thus 23 new forms had been found in the study of only approximately 70 crystals from a locality which had produced thousands of crystals of datolite - a fairly dependable indication that additional studies based upon the mineral from this locality might produce interesting results.

While a resident at Springfield, Massachusetts, between February, 1918, and April, 1919, the present writer had opportunity at frequent intervals to visit the quarries which yield the datolite. The modes of occurrence of the datolite and associated minerals were carefully observed with a view of describing the locality, and the crystallo-

\footnotetext{
1 Bull. 98, N. Y. State Mus., pp. 19-22, 1905.

2 Amer. Journ. Scl., vol. 22, p. 21, 1906.

${ }^{3}$ Zeitschr. Kryst., vol. 48, p. $652,1910$.

1 Ungemach. Zeitschr. Kryst., vol. 49, p. 470, 1911.
} 
graphic and other characters of the several minerals, with a discussion of their paragenesis and origin. Several shorter preliminary papers on various subjects relating to the locality have already been published. It was planned to make the present paper final and complete, but the crystallographic data on the datolite has assumed such proportions that it has been decided to reserve discussion of other subjects for another and final paper to be presented shortly. The following discussion of the crystallography of the Westfield datolite is based upon a very thorough acquaintance with the material. While at the quarries these specimens were selected with the view of securing as many variations in habit as might occur. Speci-

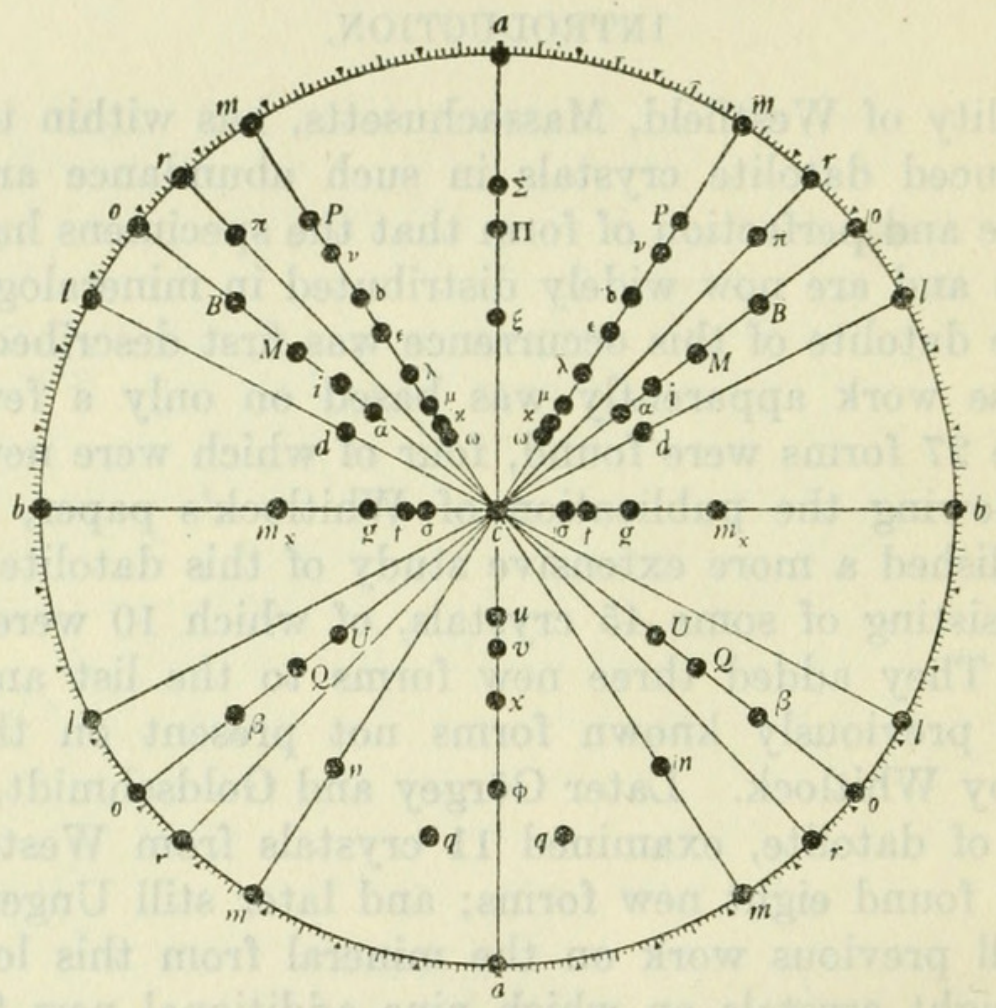

Fig. 1.-STEREOGRAPHIC PROJECTION SHOWING THE COMMON FORMS OCCURRING ON DATOLITE, PLOTTED IN THE DANa orientation. THE SYMMETRY IS EXPRESSEd BY THE FALLING OF tHE FORMS IN VERTICAL ZONES.

mens from unusual situations were especially sought, and all of the quarries were systematically sampled at various times while work was in progress. The United States National Museum had already acquired several excellent exhibition specimens of this datolite which were available for study, and in addition to these and the collection made by the writer a lot of some 35 specimens collected over a period of several years following the opening of the quarries was secured by exchange from Mr. William L. Fitts, of Springfield. The entire stock of this material held by Ward's Natural Science Establishment was also borrowed for study. From this large number of specimens about 200 crystals were selected for study, and after numerous preliminary measurements about two-thirds of this number were eliminated as duplicates. The series of about 50 crystals which was completely studied represents a concentration containing 
all the unusual forms and variations in habit occurring in upward of a thousand crystals. After much work had so familiarized the writer with the datolite and the peculiarities of outline and etching of the various forms that almost any given crystal could be oriented and its forms identified with a fair degree of accuracy by simple vision, the Westfield datolite specimens in the Brush collection of Yale University and in several private collections were examined without revealing any habits or any prominent forms not represented in the writer's final series of crystals.

\section{METHODS.}

The study of the datolite was begun and carried through the examination of some 30 crystals by zonal measurement with a Fuess 1-

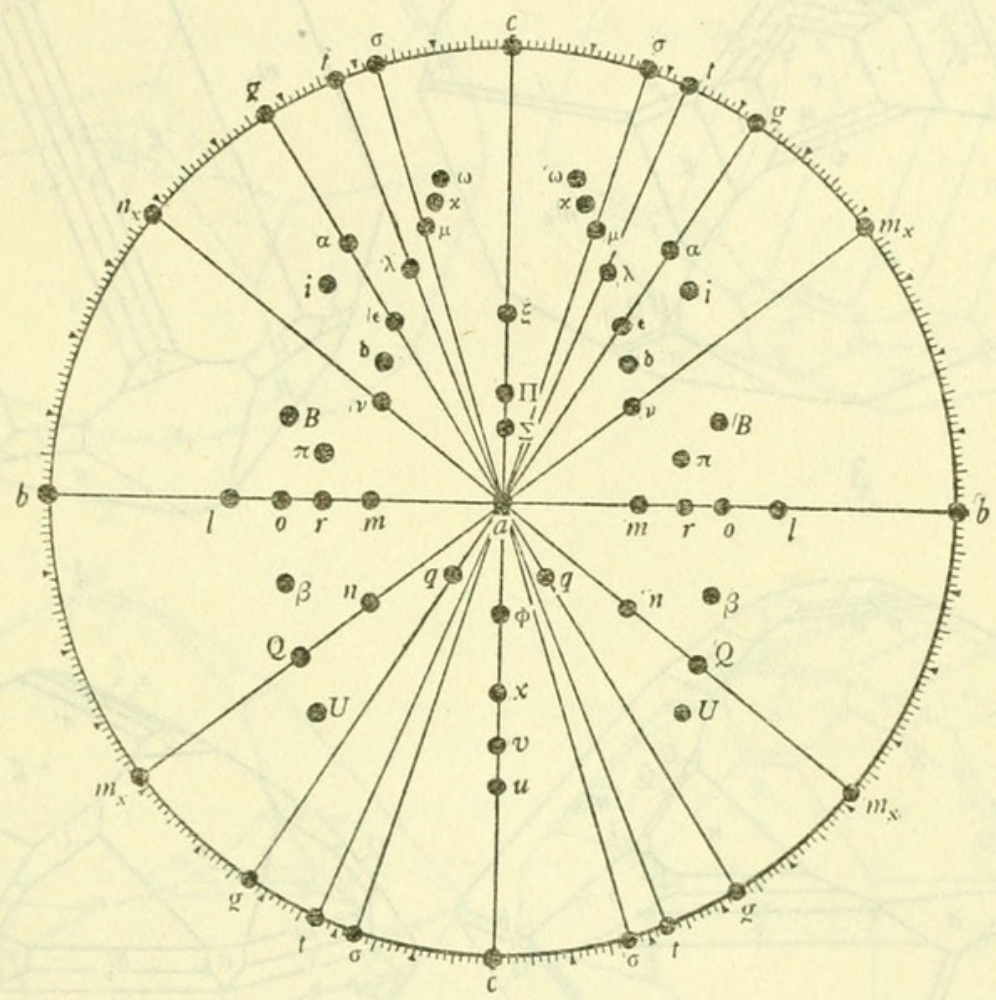

Fig. 2.-STEReographic projection SHOWINg tHe SAME Forms as Figure 1 bUt plotted in the GOLDSCHMidT ORIENTATION. THE POORER EXPRESSION OF THE SYMMETRY IS APPARENT.

circle goniometer, the symmetry relations of the various forms being worked out in stereographic projection, many of the forms being identified graphically. Despite the pronounced zonal relations existing between the various forms on datolite this method was more or less unsatisfactory, and the attendant trigonometric calculations were so tedious and consumed so much time that the problem was finally laid aside for more than a year, since it was obvious that the work could be done much more easily and simply by using a Goldschmidt 2-circle goniometer and attendant methods. Recently such an instrument has become available and the work which had been so difficult by the older system became fairly easy. The measurements made by the 1-circle goniometer were all rejected and the crystals remeas- 
ured by the newer instrument. The numerous calculations of angles given in the tables were made by the use of Goldschmidt's formulas and the crystal drawings, which had been made by older methods using axial crosses, were redrawn, for the sake of the greater accuracy attainable, from the gnomonic projection. It was possible with the 2-circle goniometer to measure many faces which it was practically impossible to measure zonally. It may be appropriate to state that

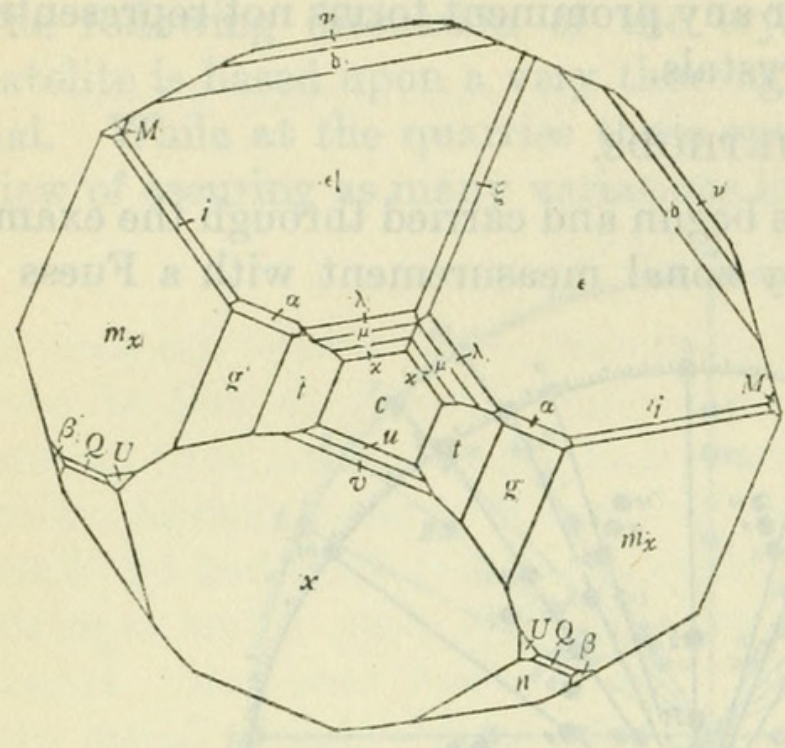

3

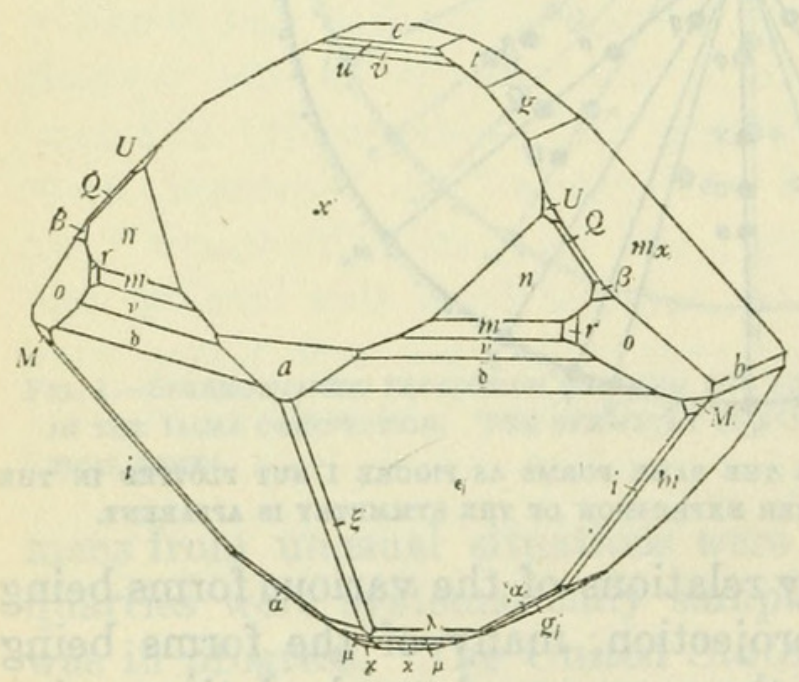

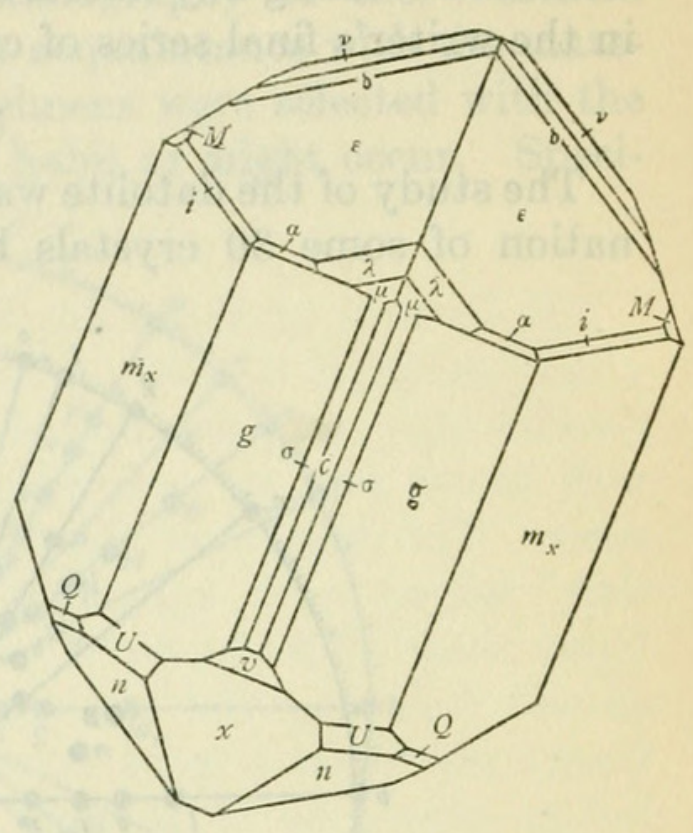

4

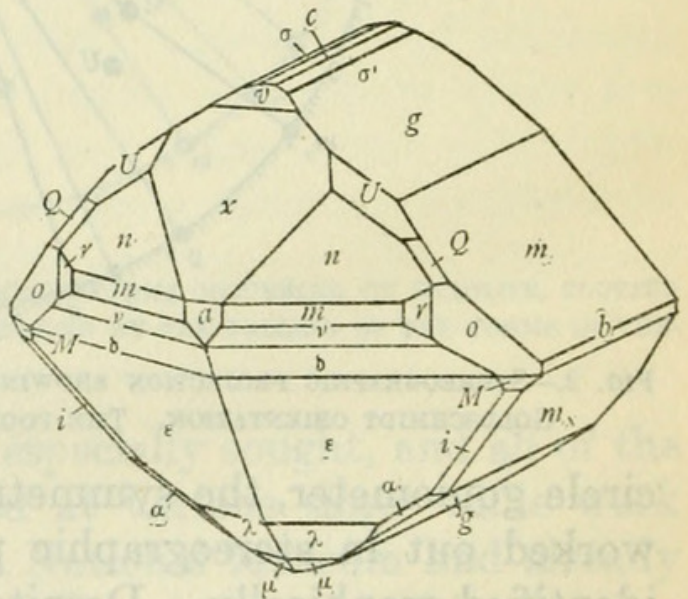

FIGS. 3-4.-3, ORTHOGRAPHIC AND CLINOGRAPHIC PROJECTIONS SHOWING A CRYSTAL OF TYPE 1 , THIS BEING THE DEVELOPMENT OF MOST FREQUENT OCCURRENCE AT WESTFIELD. 4, ORTHOGRAPHIC AND CLINOGRAPHIC PROJECTIONS OF CRYSTAL 2, PRISMATIC BY ELONGATION ON THE $a$ AXIS.

the writer, who up to this time had used only the 1-circle goniometer and attendant methods of plotting, projection, calculation, and drawing, is thoroughly convinced of the incomparable superiority of the 2-circle goniometer and the methods devised to accompany its use.

It is necessary in measuring these datolites to handle on the goniometer some large and decidedly awkward crystals, since many of the rarer forms are practically confined to the largest crystals. The 
average diameter of the crystals measured was approximately $1 \mathrm{~cm}$., but crystals up to $3 \mathrm{~cm}$. in diameter were measured at times. In these cases it is often necessary to shift the crystal backward and forward during measurement, thus slightly affecting the accuracy of the measurements, but the close agreement between the angles measured and the calculated angles indicates that in most cases the errors due to this cause are small. Many of the rarer forms which are present as small faces are characteristically etched and dull, and

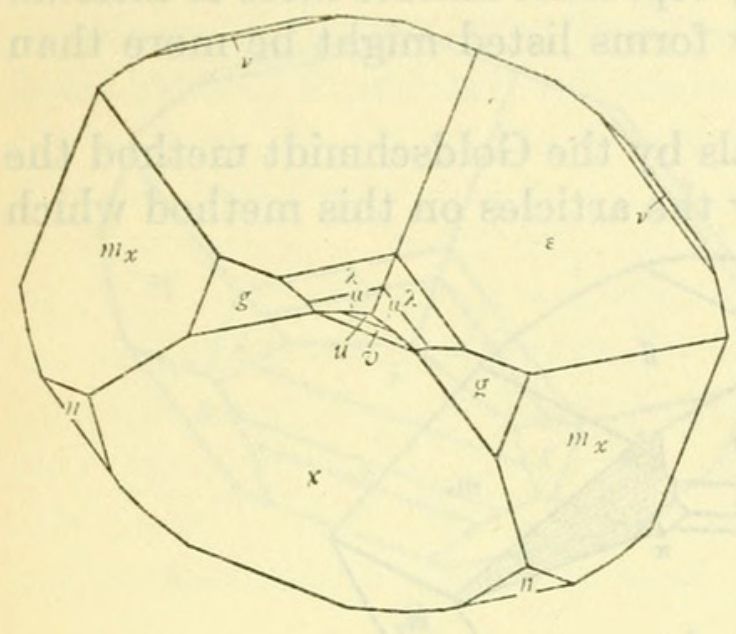

5

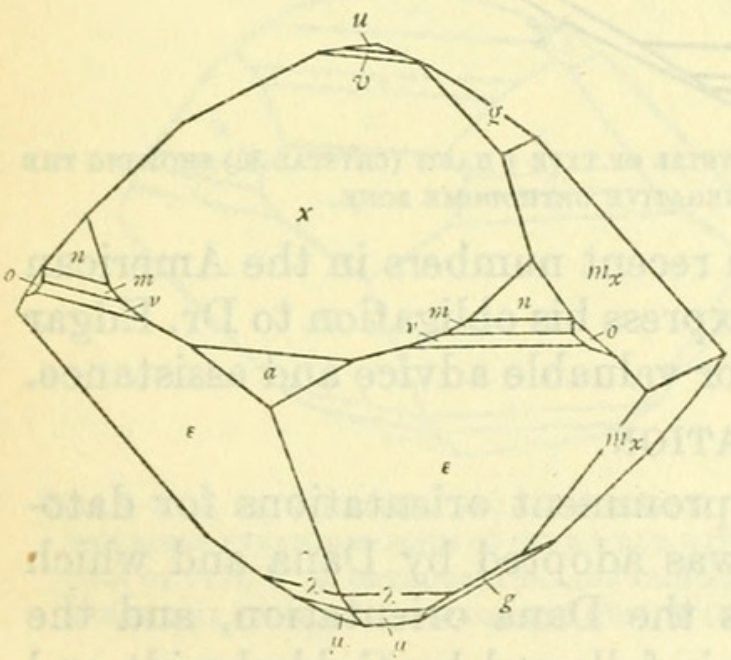

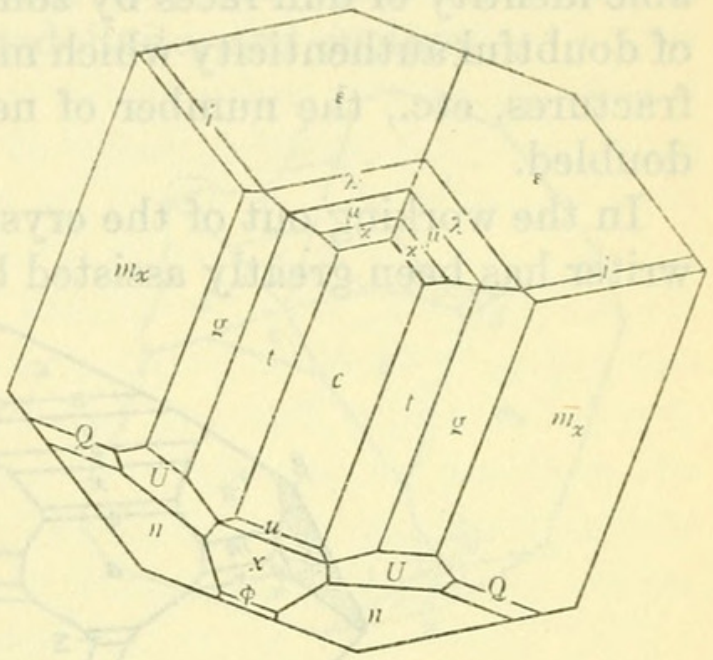

6

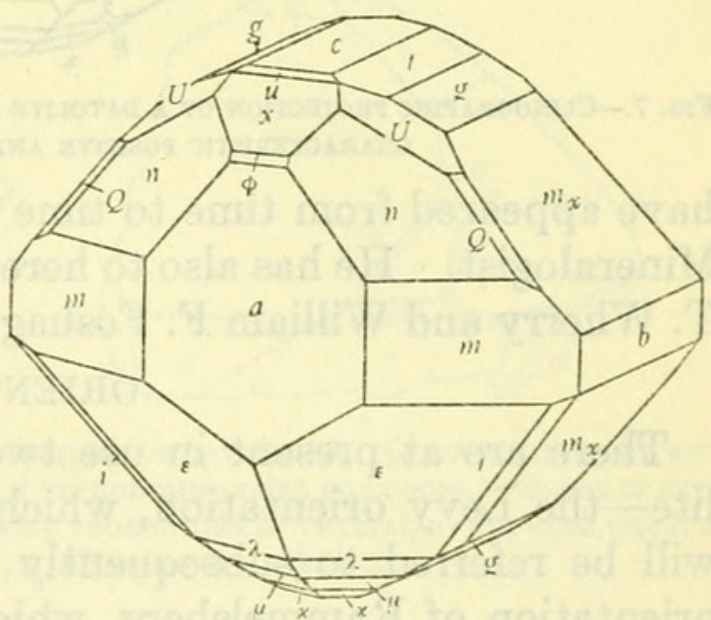

FIGS. 5-6.-5, ORTHOGRAPHIC AND CLINOGRAPHIC PROJECTIONS OF SYMMETRICALLY DEVELOPED DATOLITE CRYSTAL OF THE ACUTE HABIT DESIGNATED TYPE 2 BY KRAUS AND COOK. A COMMONLY OCCURRING HABIT AT WESTFIELD. 6, ORTHOGRAPHIC AND CLINOGRAPHIC PROJECTIONS OF A SYMMETRICALLY DEVELOPED CRYSTAL OF THE PRISMATIC TYPE WITH LARGE DEVELOPMENT OF $a$ (100), DESIGNATED TYPE 3 BY KRAUS AND COOK. SHOWS UNUSUAL FORM $\varphi(101)$.

many faces which are clearly visible reflect no light at all. Many measurements are rendered inaccurate, even though the signal was clearly discernible, by the fact that the illumination was insufficient to render the cross hairs visible and the signal could only be brought to an approximation of the center of the field. In many cases small and partly etched faces which give only a faint signal are hard to accurately measure, because they fall so near other larger and highly 
polished faces that the brilliant signals in the field render it almost impossible for the eye to distinguish the fainter signals. In general no face was considered which did not yield an unmistakable signal, and, conversely, no signal was measured unless its face was readily visible under a lens. In many cases a single crystal will yield a measurable signal from a face representing a form which is represented on all other crystals only as dull etched faces yielding no reflection of light. Were more attention paid to working out the probable identity of dull faces by zonal relations and to measuring signals of doubtful authenticity which may represent minute faces or internal fractures, etc., the number of new forms listed might be more than doubled.

In the working out of the crystals by the Goldschmidt method the writer has been greatly assisted by the articles on this method which

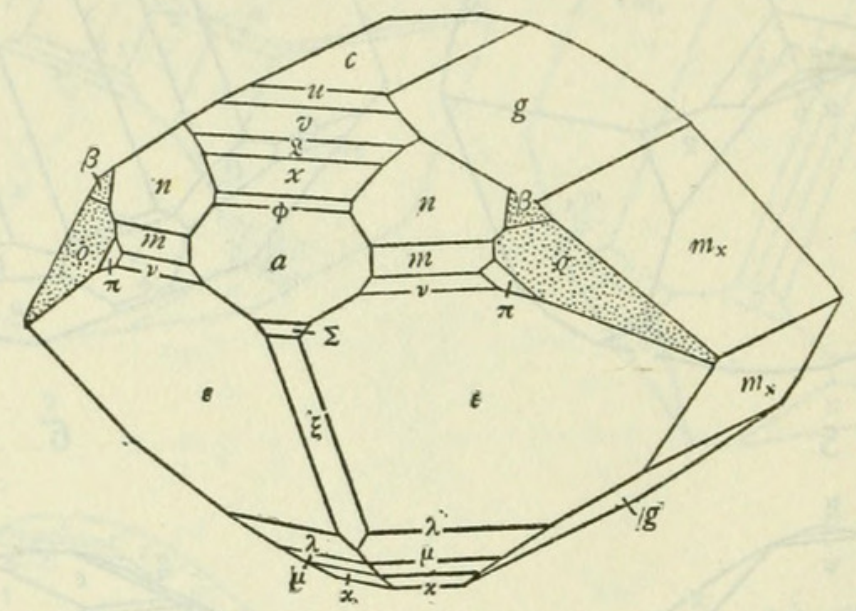

Fig. 7.-Clinographic projection of a Datolite CRystal of type 4 Habit (CRYSTAL 36) SHowing THE CHARACTERISTIC POSITIVE AND NEGATIVE ORTHODOME ZONE.

have appeared from time to time in recent numbers in the American Mineralogist. He has also to here express his obligation to Dr. Edgar T. Wherry and William F. Foshag for valuable advice and assistance. ORIENTATION.

There are at present in use two prominent orientations for datolite - the Levy orientation, which was adopted by Dana and which will be referred to subsequently as the Dana orientation, and the orientation of Rammelsberg, which is followed by Goldschmidt and is best known as the Goldschmidt orientation. In the Goldschmidt orientation the form which in the Dana orientation is the dome $g(012)$ becomes the unit prism $m(110)$. The axes are thus interchanged, axis $a$, Dana orientation, becoming axis $c$, Goldschmidt orientation, and $\frac{1}{2}$ axis $c$, Dana orientation, becoming axis $a$, Goldschmidt orientation. The axial ratios for the two orientations are then as follows:

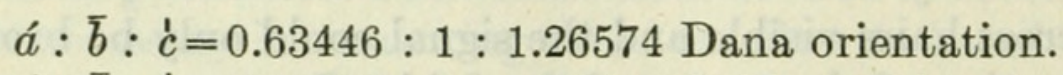

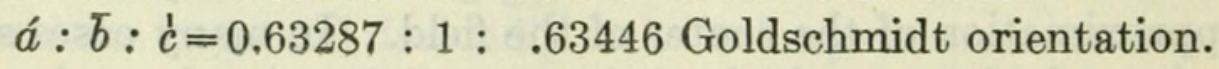


The Dana orientation has naturally been preferred by most American authors and also by Ungemach and other European authors who still use the 1-circle goniometer. The majority of German mineralogists and most others who use the 2-circle goniometer and Goldschmidt methods have used the Goldschmidt orientation. Various advocates of each of these two methods have endeavored to justify their preference by showing either that the orientation which they favored gave simpler indices or that it better illustrated the relationships existing between datolite and the other members of the group which includes homilite, gadolinite, and euclase.

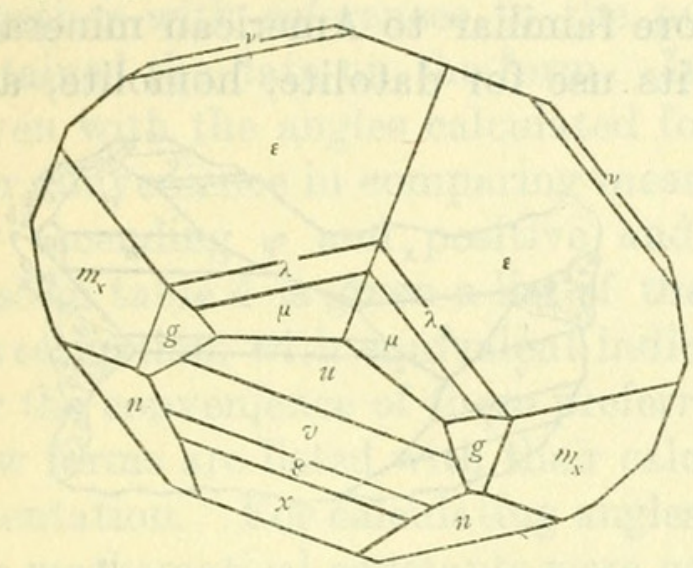

8

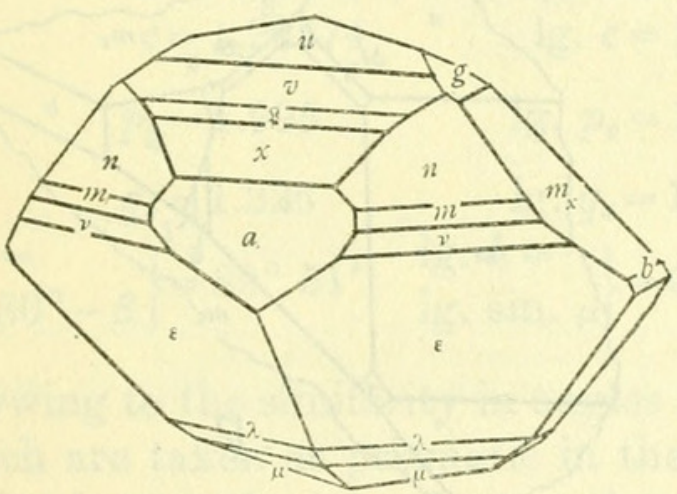

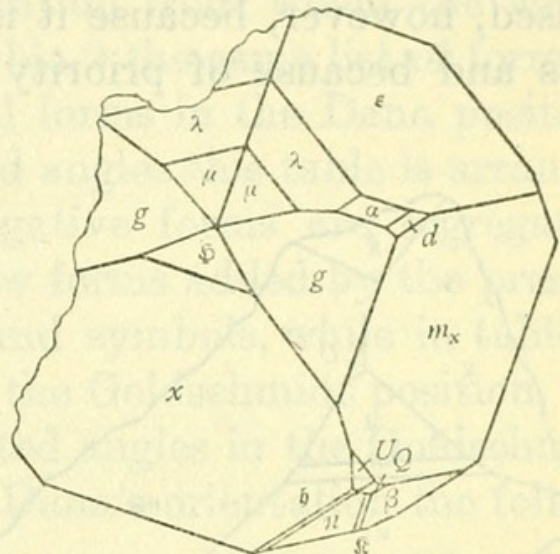

9

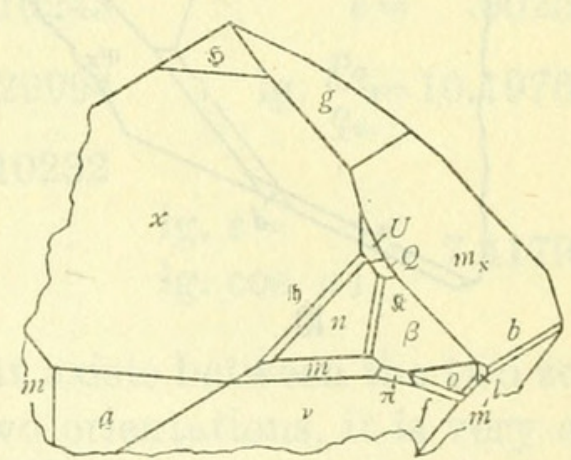

Figs. 8-9.-8, ORThOGRAPHIC AND CLINOGRAPHIC PROJECTIONS OF CRYSTAL 28. AN UNUSUAL HABIT With THE STEEP PYRAMIDAL FORM OF TYPE 2 BUT WITH AN ORTHODOME SERIES INCLUDING $\&$ (205) AS IN CRYSTALS OF TYPE 4. 9, ORTHOGRAPHIC AND CLINOGRAPHIC PROJECTIONS OF CRYSTAL B9 SHOWING UNUSUAL PYRAMIDAL FORM WITH THE FORMS h (768), $\Omega(454), f_{1},(\overline{3} 61)$, AND $m_{1},(\overline{12} .25 .1)$.

The difference in relative simplicity of indices is not greatly in favor of either orientation when all the known forms are considered, although it is possible to select groups of forms or zones which yield comparisons favoring either position. This is well illustrated by the method of adding the indices of the same forms for the two orientations. Thus, when the sums of the indices of the forms given in Table 1 are obtained the indices for the Dana orientation total 1,101, while the sum of the indices for the same forms in the Goldschmidt orientation is 1,113 , the difference being too small to be of any importance. Similarly, the sum of the indices of the new forms 
given below is 811 for the Dana position and 927 for the Goldschmidt position the difference in each instance favoring the former orientation. In the majority of occurrences of crystallized datolite the crystals are so developed that the zone adopted as prismatic by Goldschmidt is much more prominent and recognizable than the zone taken as prismatic in the Dana orientation, this constituting the most practical argument in support of the Goldschmidt orientation, as it is consequently much easier to adjust crystals in polar position for measurement on the 2-circle goniometer in this orientation than in that of Dana. In the present work the Dana position is used, however, because it is more familiar to American mineralogists and because of priority of its use for datolite, homolite, and

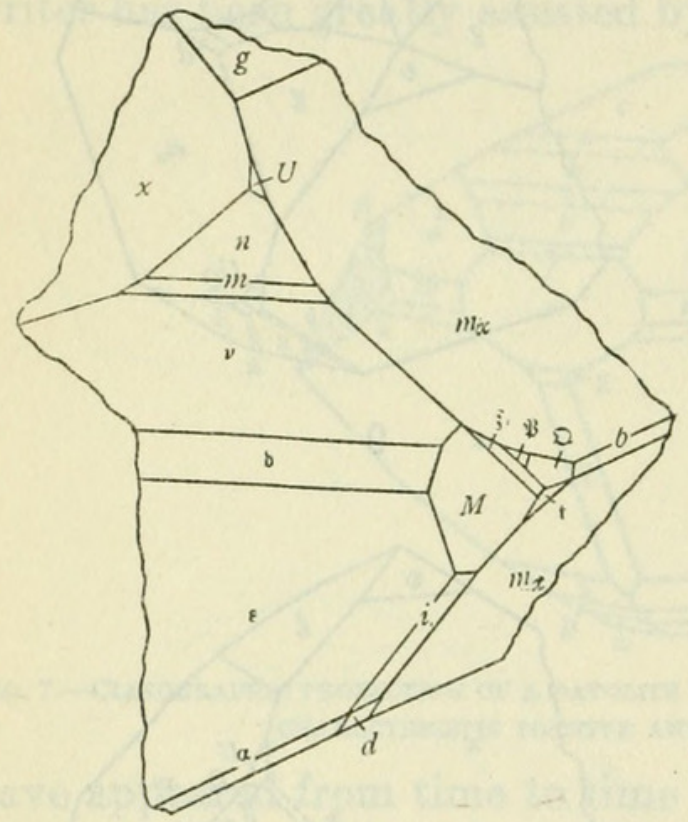

10

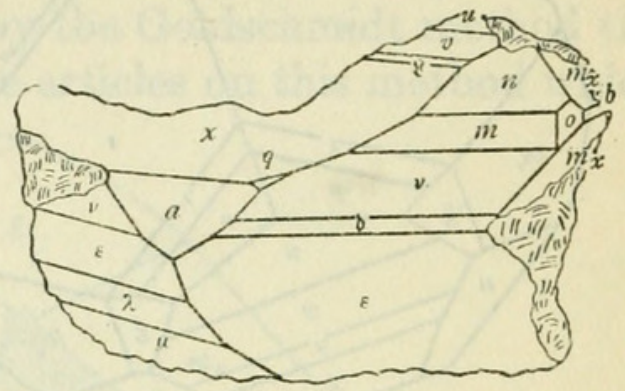

II

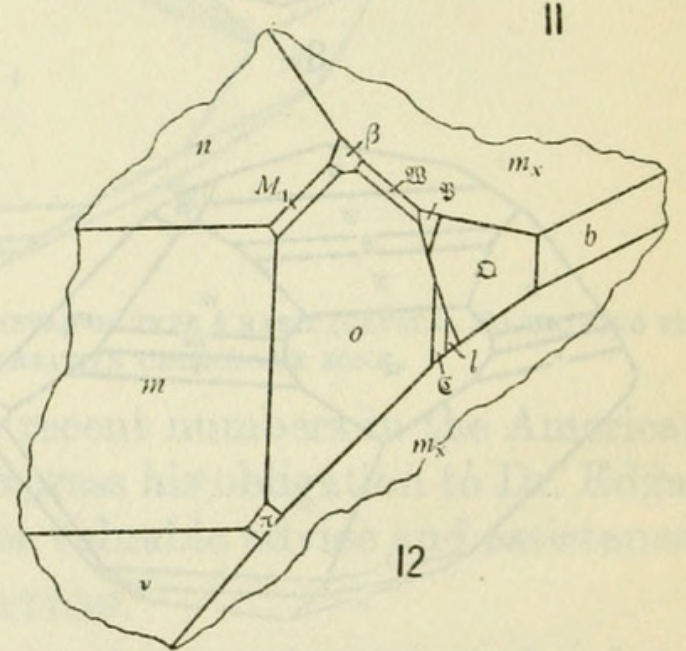

Figs. 10-12.-10, PORTION OF CRYSTAL B 7. CLINOGRAPHIC PROJECTION SHOWING NEW FORMS z ( $\overline{2} 63), \mathfrak{B}(192)$, $\mathfrak{Q}$ (1.10.2), AND T (1.20.15). 11, CRYSTAL B8. CLINOGRAPHIC PROJECTION SHOWING DEVELOPMENT OF THE CRYSTAL AND THE NEW FORM $\mathfrak{l}(205)$. 12, CRYSTAL B8. CLINOGRAPHIC PROJECTION OF DETAIL SHOWING $M_{1}(231), \mathfrak{B}(382), \mathfrak{B}(192), \mathfrak{Q}(1.10 .2)$, ๔ (380).

gadolinite. The indices in general are not simpler in the Goldschmidt orientation, and the Dana orientation shows the crystallographic and optical relationships between the several members of the group equally well. Perhaps the most convincing support for this orientation is the symmetry relations existing between the common forms These relations are brought out by the stereographic projections, figures 1 and 2, which show the zonal relations existing between the commonly occurring forms for datolite in the two orientations.

The use of two orientations for datolite has been a source of considerable confusion since new forms have been described in either 
orientation according to the preference of the worker. The investigators using the 2-circle goniometer have been compelled to choose Goldschmidt's orientation or undertake the alternative of recalculating long tables of angles and of converting all forms to indices in terms of the Dana orientation. This has been done by the writer, and the tables, which represent a considerable expenditure of time and labor, are here reproduced for the benefit of future workers who may prefer the Dana position. Thus in table 1 is given a list of all known forms described for datolite, with the letters assigned them and the equivalent indices and symbols in the two orientations, together with references to the publication from which the writer obtained the data on the form. In table 2 the same list of forms is given with the angles calculated for all forms in the Dana position. For convenience in comparing measured angles this table is arranged by ascending $\varphi$ and positive and negative forms are segregated. Also in table 4 is given a list of the new forms added by the present investigation, with equivalent indices and symbols, while in table 6 , for the convenience of those preferring the Goldschmidt position, the new forms are listed with their calculated angles in the Goldschmidt orientation. For calculating angles in Dana's orientation the following mathematical constants were used:

$$
\begin{aligned}
& a=.63446 \\
& \text { lg. } a=9.80243 \\
& h=1.0000 \\
& c=1.26574 \\
& \text { lg. } c=10.10243 \\
& e=.0025 \\
& p_{o}=1.995 \\
& \text { lg. } p_{o}=10.29994 \\
& q_{0}=1.226 \\
& \left.\begin{array}{l}
\mu= \\
180^{\circ}-\beta
\end{array}\right\}=89^{\circ} 51^{\prime} \\
& \text { lg. } q_{o}=10.10232 \\
& \text { lg. } \frac{p_{o}}{q_{o}}=10.19762 \\
& \left.\begin{array}{l}
\text { lg. } h= \\
\text { lg. } \sin . \mu
\end{array}\right\}=0 \\
& \left.\begin{array}{l}
\lg \cdot e= \\
\lg \cdot \cos \cdot \mu
\end{array}\right\}=7.41797
\end{aligned}
$$

Owing to the similarity in angles that exists between the two zones which are taken as prismatic in the two orientations, it is very easy to inadvertently interchange these. The very close similarity is shown by the following comparison of angles:

$$
\begin{array}{rlrlrl}
m(110) \wedge m^{\prime \prime \prime}(1 \overline{1} 0) & =64^{\circ} 47^{\prime} & g(012) \wedge & g^{\prime}(0 \overline{1} 2) & =64^{\circ} 40^{\prime} . \\
e(320) \wedge e^{\prime \prime \prime}(3 \overline{2} 0) & =45^{\circ} 51^{\prime} & t(013) \wedge & t^{\prime}(0 \overline{1} 3) & =45^{\circ} 45^{\prime} . \\
\Delta(210) \wedge \Delta^{\prime \prime \prime}(2 \overline{1} 0) & =35^{\circ} 12^{\prime} & \sigma(014) \wedge & \sigma^{\prime}(0 \overline{1} 4) & =35^{\circ} 07^{\prime} . \\
o(120) \wedge o^{\prime}(\overline{1} 20) & =76^{\circ} 29^{\prime} & m_{x}(011) \wedge & \bar{m}_{x}(01 \overline{1})=76^{\circ} 37^{\prime} .
\end{array}
$$

In addition to this common cause of confusion is the fact that the mineral approximates so very closely to orthorhombic symmetry $\left(\beta=89^{\circ} 51 \frac{1}{2}^{\prime}\right)$ that the difference in angle between corresponding positive and negative forms is very small, and it is consequently possible to rotate crystals $180^{\circ}$ from true position, especially if the angles measured are not very exact and the crystal is simple in com- 
bination. The danger of committing errors of orientation is naturally much greater with simple crystals than with highly modified crystals showing a large number of forms. In some rare instances it is possible to completely measure a crystal of this mineral without obtaining measurements which will show conclusively how it should be oriented, the difficulty then having to be settled by optical examination. The various characteristic etchings and irregularities which occur on the faces are of greatest value in orienting the crystals, and for this reason these peculiarities are described in considerable detail below. While every crystal measured by the writer has been carefully considered and the possibility of error in orientation carefully weighed, it is possible though improbable that one or more crystals were measured in a wrong position.

TABLE 1.-Datolite.

Giving a list of forms previously recorded for datolite with equivalent indices and symbols in the Dana (Levy) and Goldschmidt (Rammelsberg) orientations.

\begin{tabular}{|c|c|c|c|c|c|}
\hline 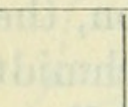 & Dana ori & ntation. & $\begin{array}{l}\text { Golds } \\
\text { orient }\end{array}$ & $\begin{array}{l}\text { idt } \\
\text { on. }\end{array}$ & 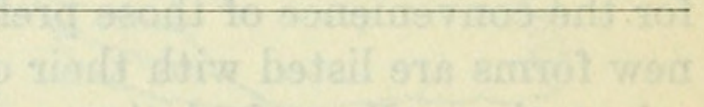 \\
\hline & Miller. & $\begin{array}{l}\text { Gold- } \\
\text { schmidt. }\end{array}$ & Miller. & $\begin{array}{l}\text { Gold- } \\
\text { schmidt. }\end{array}$ & 16 \\
\hline $\begin{array}{l}a \\
b \\
c\end{array}$ & $\begin{array}{l}100 \\
010 \\
001\end{array}$ & $\begin{array}{rr}\infty & 0 \\
0 & \infty \\
& 0\end{array}$ & $\begin{array}{l}001 \\
010 \\
100\end{array}$ & $\begin{array}{rr} & 0 \\
0 & \infty \\
\infty & 0\end{array}$ & $\begin{array}{l}\text { Goldschmidt Winkeltabellen. } \\
\text { Do. } \\
\text { Do. }\end{array}$ \\
\hline $\begin{array}{c}m(M) \\
0 \\
l\end{array}$ & $\begin{array}{l}110 \\
120 \\
130\end{array}$ & $\begin{array}{lr} & \infty \\
\infty & 2 \\
\infty & 3\end{array}$ & $\begin{array}{l}011 \\
021 \\
031\end{array}$ & $\begin{array}{ll}0 & 1 \\
0 & 2 \\
0 & 3\end{array}$ & $\begin{array}{l}\text { Do. } \\
\text { Do. } \\
\text { Do. }\end{array}$ \\
\hline $\begin{array}{l}\Theta \\
\Delta \\
r\end{array}$ & $\begin{array}{l}140 \\
210 \\
230\end{array}$ & $\begin{array}{rr}\infty & 4 \\
2 & \infty \\
\infty & \frac{3}{2}\end{array}$ & $\begin{array}{l}041 \\
012 \\
032\end{array}$ & $\begin{array}{ll}0 & 4 \\
0 & \frac{1}{2} \\
0 & \frac{3}{2}\end{array}$ & $\begin{array}{l}\text { Ungemach, Zeits. Kryst., v. 49, p. 470, } 1911 . \\
\text { Goldschmidt Winkeltabellen. } \\
\text { Do. }\end{array}$ \\
\hline $\begin{array}{l}N \\
\eta \\
s\end{array}$ & $\begin{array}{l}340 \\
410 \\
530\end{array}$ & $\begin{array}{rr}\infty & \frac{4}{3} \\
4 & \infty \\
\frac{8}{3} & \infty\end{array}$ & $\begin{array}{l}043 \\
014 \\
035\end{array}$ & $\begin{array}{ll}0 & \frac{4}{3} \\
0 & \frac{1}{4} \\
0 & \frac{3}{8}\end{array}$ & $\begin{array}{l}\text { Hawkins, Amer. Journ. Sci., v. } 39, \text { p. 474, } 1915 . \\
\text { Goldschmidt Winkeltabellen. } \\
\text { Ungemach, Zeits. Kryst., v. 49, p. 470, } 1911 .\end{array}$ \\
\hline$\underset{g}{m_{x}(m)}$ & $\begin{array}{l}320 \\
011 \\
012\end{array}$ & \begin{tabular}{lc|}
$\frac{3}{2}$ & $\infty$ \\
0 & 1 \\
0 & $\frac{1}{2}$
\end{tabular} & $\begin{array}{l}023 \\
120 \\
110\end{array}$ & $\begin{array}{rr}0 & \frac{2}{3} \\
\infty & 2 \\
& \infty\end{array}$ & $\begin{array}{l}\text { Goldschmidt Winkeltabellen. } \\
\text { Do. } \\
\text { Do. }\end{array}$ \\
\hline $\begin{array}{l}t \\
\sigma \\
\Omega\end{array}$ & $\begin{array}{l}013 \\
014 \\
018\end{array}$ & $\begin{array}{ll}0 & \frac{1}{3} \\
0 & \frac{1}{2} \\
0 & \frac{1}{8}\end{array}$ & $\begin{array}{l}320 \\
210 \\
410\end{array}$ & $\begin{array}{l}\frac{3}{2} \infty \\
2 \infty \\
4 \infty\end{array}$ & $\begin{array}{l}\text { Do. } \\
\text { Do. } \\
\text { Do. }\end{array}$ \\
\hline$m_{z}$ & $0-1-10$ & $0 \frac{2}{10}$ & 510 & $5 \infty$ & Kraus \& Cook, Amer. Journ. Sci., v. 22, p. 21, \\
\hline$\underset{h}{S}$ & $\begin{array}{l}021 \\
023\end{array}$ & $\begin{array}{ll}0 & 2 \\
0 & \frac{2}{3}\end{array}$ & $\begin{array}{l}140 \\
340\end{array}$ & $\begin{array}{ll}\infty & 4 \\
\infty & \frac{4}{3}\end{array}$ & $\begin{array}{l}\text { Goldschmidt Winkeltabellen. } \\
\text { Do. }\end{array}$ \\
\hline$m_{y}$ & 067 & $0 \quad \frac{6}{7}$ & $7-12-0$ & $\infty \frac{12}{7}$ & $\begin{array}{l}\text { Kraus \& Cook, Amer. Journ. Sci., v. 22, p. 21, } \\
1906 .\end{array}$ \\
\hline$\underset{x}{\phi}$ & $\begin{array}{l}101 \\
102\end{array}$ & $\begin{array}{l}+110 \\
+\frac{1}{2} 0\end{array}$ & $\begin{array}{l}102 \\
101\end{array}$ & $\begin{array}{ll}+\frac{1}{2} & 0 \\
+1 & 0\end{array}$ & $\begin{array}{l}\text { Goldschmidt Winkeltabellen. } \\
\text { Do. }\end{array}$ \\
\hline $\begin{array}{l}v \\
u \\
p\end{array}$ & $\begin{array}{l}103 \\
104 \\
106\end{array}$ & 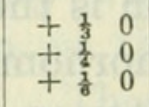 & $\begin{array}{l}302 \\
201 \\
301\end{array}$ & $\begin{array}{ll}+\frac{3}{2} & 0 \\
+2 & 0 \\
+3 & 0\end{array}$ & $\begin{array}{l}\text { Do. } \\
\text { Do. } \\
\text { Do. }\end{array}$ \\
\hline $\begin{array}{l}q \\
\stackrel{q}{I}\end{array}$ & $\begin{array}{r}1-0-14 \\
201 \\
203\end{array}$ & $\begin{array}{l}+\frac{1}{16} \\
+20 \\
+20\end{array}$ & $\begin{array}{l}701 \\
104 \\
304\end{array}$ & $\begin{aligned} &+70 \\
&+\quad 1 \\
&+\frac{3}{4} 0\end{aligned}$ & $\begin{array}{l}\text { Palache, Zeits. Kryst., v. 47, p. 583, } 1910 . \\
\text { Goldschmidt Winkeltabellen. } \\
\text { Palache, Zeits. Kryst., v. 47, p. 583, } 1910 .\end{array}$ \\
\hline$s$ & $\begin{array}{l}302 \\
304 \\
308\end{array}$ & $\begin{array}{ll}+\frac{3}{2} & 0 \\
+\frac{3}{3} & 0 \\
+\frac{3}{8} & 0\end{array}$ & $\begin{array}{l}103 \\
203 \\
403\end{array}$ & $\begin{array}{ll}+\frac{1}{3} & 0 \\
+\frac{2}{3} & 0 \\
+\frac{4}{3} & 0\end{array}$ & $\begin{array}{l}\text { Goldschmidt Winkeltabellen. } \\
\text { Do. } \\
\text { Gorgey \& Gdt., Zeits. Kryst., . 48, p. } 652 \text {, }\end{array}$ \\
\hline
\end{tabular}


TABLE 1.-Datolite-Continued.

\begin{tabular}{|c|c|c|c|c|c|}
\hline & \multicolumn{2}{|c|}{ Dana orientation. } & \multicolumn{2}{|c|}{$\begin{array}{l}\text { Goldschmidt } \\
\text { orientation. }\end{array}$} & \multirow{2}{*}{ Reference. } \\
\hline & Miller. & $\begin{array}{c}\text { Gold- } \\
\text { schmidt. }\end{array}$ & Miller. & $\begin{array}{l}\text { Gold- } \\
\text { schmidt. }\end{array}$ & \\
\hline $\begin{array}{c}k: \\
j \\
y\end{array}$ & $\begin{array}{r}3-0-10 \\
502 \\
601\end{array}$ & 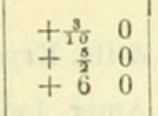 & $\begin{array}{r}503 \\
105 \\
1-0-12\end{array}$ & $\begin{array}{l}+\frac{5}{3} 0 \\
+\frac{1}{5} 0 \\
+\frac{1}{12}\end{array}$ & $\begin{array}{l}\text { Ungemach, Zeits. Kryst., v. } 49 \text {, p. } 470,1911 . \\
\text { Do. } \\
\text { Do. }\end{array}$ \\
\hline $\begin{array}{l}I I \\
\xi \\
a\end{array}$ & $\begin{array}{l}\overline{1} 01 \\
102 \\
104\end{array}$ & 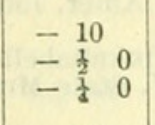 & $\begin{array}{l}\overline{1} 02 \\
\frac{1}{2} 01 \\
\end{array}$ & $\begin{array}{ll}-\frac{1}{2} & 0 \\
-1 & 0 \\
-2 & 0\end{array}$ & $\begin{array}{l}\text { Goldschmidt Winkeltabellen. } \\
\text { Do. } \\
\text { Do. }\end{array}$ \\
\hline$\stackrel{z}{2}$ & $\begin{array}{l}\overline{2} 01 \\
\overline{3} 02 \\
\overline{3} 04\end{array}$ & $\begin{array}{ll}-20 & \\
-\frac{3}{2} & 0 \\
-\frac{3}{4} & 0\end{array}$ & $\begin{array}{l}\overline{1} 04 \\
\overline{1} 03 \\
203\end{array}$ & $\begin{array}{ll}-\frac{1}{4} & 0 \\
-\frac{1}{3} & 0 \\
-\frac{2}{3} & 0\end{array}$ & $\begin{array}{l}\text { Do. } \\
\text { Do. } \\
\text { Do. }\end{array}$ \\
\hline$\tau$ & $\begin{array}{r}702 \\
\overline{11}-0-2 \\
111\end{array}$ & $\begin{array}{ll}-\frac{7}{2} & 0 \\
-\frac{12}{2} & 0 \\
+ & 1\end{array}$ & $\begin{array}{r}\overline{1} 07 \\
1-0-11 \\
122\end{array}$ & $\begin{array}{ll}-\frac{1}{7} & 0 \\
-\frac{1}{1} & 0 \\
+\frac{1}{2} & 1\end{array}$ & $\begin{array}{l}\text { Do. } \\
\text { Ungemach, Zeits. Kryst., v. 49, p. 470, } 1911 . \\
\text { Goldschmidt Winkeltabellen. }\end{array}$ \\
\hline $\begin{array}{l}\Lambda \\
L \\
W\end{array}$ & $\begin{array}{l}112 \\
113 \\
114\end{array}$ & $\begin{array}{l}+\frac{1}{2} \\
+\frac{1}{3} \\
+\frac{1}{2}\end{array}$ & $\begin{array}{l}111 \\
322 \\
211\end{array}$ & $\begin{array}{l}+1 \\
+\frac{3}{2} \\
+21\end{array}$ & $\begin{array}{l}\text { Do. } \\
\text { Do. } \\
\text { Do. }\end{array}$ \\
\hline í & $\begin{array}{r}115 \\
116 \\
1-1-18\end{array}$ & $\begin{array}{lr}+ & \frac{1}{6} \\
+ & \frac{1}{6} \\
+ & \frac{1}{18}\end{array}$ & $\begin{array}{l}522 \\
311 \\
911\end{array}$ & $\begin{array}{ll}+\frac{8}{2} & 1 \\
+3 & 1 \\
+9 & 1\end{array}$ & $\begin{array}{l}\text { Do. } \\
\text { Do. } \\
\text { Eakle, Bull. Dept. Geol. U. Cal., v. 2, p. 318, } 1900 .\end{array}$ \\
\hline $\begin{array}{l}\beta \\
Q \\
U\end{array}$ & $\begin{array}{l}121 \\
122 \\
123\end{array}$ & 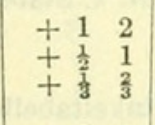 & $\begin{array}{l}142 \\
121 \\
342\end{array}$ & $\begin{array}{l}+\frac{1}{2} 2 \\
+12 \\
+\frac{3}{2}\end{array}$ & $\begin{array}{l}\text { Goldschmidt Winkeltabellen. } \\
\text { Do. } \\
\text { Do. }\end{array}$ \\
\hline$\stackrel{r}{(k)}$ & $\begin{array}{l}124 \\
132 \\
133\end{array}$ & 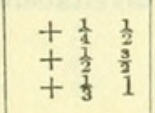 & $\begin{array}{l}221 \\
131 \\
362\end{array}$ & $\begin{array}{ll}+ & 2 \\
+13 \\
+\frac{3}{2} & 3\end{array}$ & $\begin{array}{l}\text { Do. } \\
\text { Whitlock, Sch. Mines Quar., v. } 31, \text { p. 225, } 1905 . \\
\text { Goldschmidt Winkeltabellen. }\end{array}$ \\
\hline $\begin{array}{l}1 \\
\rho \\
\mathfrak{D}\end{array}$ & $\begin{array}{l}144 \\
148 \\
211\end{array}$ & 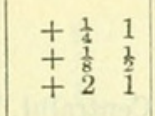 & $\begin{array}{l}241 \\
441 \\
124\end{array}$ & $\begin{array}{l}+24 \\
+\quad 4 \\
+\frac{1}{2}\end{array}$ & $\begin{array}{l}\text { Do. } \\
\text { Do. } \\
\text { Do. }\end{array}$ \\
\hline $\begin{array}{c}\vartheta \\
\mathfrak{b} \\
\mathfrak{w}\end{array}$ & $\begin{array}{l}212 \\
213 \\
215\end{array}$ & 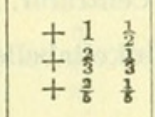 & $\begin{array}{l}112 \\
324 \\
524\end{array}$ & $\begin{array}{l}+ \\
+\frac{3}{2} \\
+\frac{1}{2} \\
+\frac{5}{4}\end{array}$ & $\begin{array}{l}\text { Do. } \\
\text { Do. } \\
\text { Do. }\end{array}$ \\
\hline $\begin{array}{l}A \\
\delta \\
M_{1}\end{array}$ & $\begin{array}{l}216 \\
221 \\
231\end{array}$ & $\begin{array}{l}+\frac{1}{3} \\
+\quad 2 \\
+23\end{array}$ & $\begin{array}{l}312 \\
144 \\
164\end{array}$ & $\begin{array}{ll}+\frac{3}{2} & \frac{1}{2} \\
+\frac{1}{4} & 1 \\
+\frac{1}{4} & \frac{3}{2}\end{array}$ & $\begin{array}{l}\text { Do. } \\
\text { Do. } \\
\text { Ungemach, Bull. Soc. Franc., v. 32, p. 397, } 1909 .\end{array}$ \\
\hline $\begin{array}{l}R \\
Y \\
g_{0}\end{array}$ & $\begin{array}{r}241 \\
255 \\
2-15-28\end{array}$ & $\begin{array}{l}+24 \\
+\frac{2}{5} \\
+\frac{1}{15} \\
+\frac{1}{28}\end{array}$ & $\begin{array}{r}184 \\
5-10-4 \\
14-15-2\end{array}$ & $\begin{array}{l}+\frac{1}{4} 2 \\
+\frac{5}{4} \frac{5}{2} \\
+7 \frac{5}{2}\end{array}$ & $\begin{array}{l}\text { Goldschmıdt Winkeltabellen. } \\
\text { Whitlock, Sch. Mines Quar., v. 31, p. 225, } 1909 . \\
\text { MeClintock, Min.Mag., v.15, p.411, } 1910 .\end{array}$ \\
\hline $\begin{array}{l}J_{1} \\
a^{*} \\
\mathfrak{b}^{\circ}\end{array}$ & $\begin{array}{l}311 \\
312 \\
313\end{array}$ & 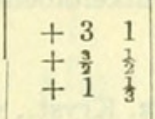 & $\begin{array}{l}126 \\
113 \\
326\end{array}$ & $\begin{array}{l}+\frac{1}{6} \frac{1}{3} \\
+\quad \frac{1}{3} \\
+\frac{1}{2}\end{array}$ & $\begin{array}{l}\text { Ungemach, Bull. Soc. Franc., v. 32, p. 397, } 1919 . \\
\text { Goldschmidt Winkeltabellen. } \\
\text { Görgey \& Gdt., Zeits. Kryst., v. 48, p. 652, } 1910 .\end{array}$ \\
\hline $\begin{array}{l}\Gamma \\
N: \\
w\end{array}$ & $\begin{array}{l}314 \\
322 \\
324\end{array}$ & 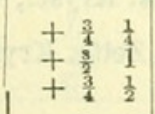 & $\begin{array}{l}213 \\
123 \\
223\end{array}$ & $\begin{array}{l}+\frac{2}{3} \\
+\frac{1}{3} \\
+\frac{1}{3} \\
+\frac{3}{3} \\
+\quad \frac{2}{3}\end{array}$ & $\begin{array}{l}\text { Goldschmidt Winkeltabellen. } \\
\text { Do. } \\
\text { Do. }\end{array}$ \\
\hline $\begin{array}{l}\dddot{q} \\
d \\
I\end{array}$ & $\begin{array}{l}362 \\
364 \\
412\end{array}$ & $\begin{array}{l}+\frac{3}{2} \\
+\frac{3}{4} \\
+2 \\
+2 \frac{3}{2}\end{array}$ & $\begin{array}{l}163 \\
263 \\
114\end{array}$ & $\begin{array}{l}+\frac{1}{3} 2 \\
+32 \\
+\quad 2 \\
+\quad \frac{1}{4}\end{array}$ & $\begin{array}{l}\text { Görgey \& Gdt., Zeits. Kryst., v. 48, p. 652, } 1910 . \\
\text { Palache, Zeits. Kryst., v. 47, p. 583,1910. } \\
\text { Ungemach, Zeits. Kryst., v. 49, p. 470, } 1911 .\end{array}$ \\
\hline$\underset{\Re}{\mathscr{\Psi}}$ & $\begin{array}{l}414 \\
421 \\
454\end{array}$ & $\begin{array}{l}+1 \frac{1}{4} \\
+42 \\
+1 \frac{5}{6}\end{array}$ & $\begin{array}{l}214 \\
148 \\
254\end{array}$ & $\begin{array}{l}+\frac{1}{2} \\
+\frac{1}{4} \\
+\frac{1}{8} \\
+\frac{1}{2} \\
+\frac{1}{2}\end{array}$ & $\begin{array}{l}\text { Goldschmidt Winkeltabellen. } \\
\text { Do. } \\
\text { Görgey \& Goldschmidt, idem. }\end{array}$ \\
\hline $\begin{array}{l}x \\
5 \\
k\end{array}$ & $\begin{array}{l}534 \\
548 \\
578\end{array}$ & $\begin{array}{l}+\frac{5}{4} \\
+\frac{3}{4} \\
+\frac{5}{8} \\
+\frac{5}{2} \\
\end{array}$ & $\begin{array}{l}235 \\
445 \\
475\end{array}$ & $\begin{array}{l}+\frac{3}{5} \\
+\begin{array}{l}5 \\
+\end{array} \\
+\frac{4}{6}\end{array}$ & $\begin{array}{l}\text { Goldschmidt Winkeltabellen. } \\
\text { Do. } \\
\text { Palache, Zeits. Kryst., v. } 47 \text {, p. } 583,1910 .\end{array}$ \\
\hline $\begin{array}{c}\kappa_{2} \\
\mathscr{U} \\
\nu\end{array}$ & $\begin{array}{l}722 \\
763 \\
111\end{array}$ & $\begin{array}{ll}+\frac{7}{2} & 1 \\
+\frac{7}{3} & 2 \\
- & 1\end{array}$ & $\begin{array}{r}127 \\
3-12-14 \\
122\end{array}$ & $\begin{array}{ll}+\frac{3}{4} & \frac{2}{7} \\
+\frac{3}{4} & \frac{6}{4} \\
-\frac{1}{2} & 1\end{array}$ & $\begin{array}{l}\text { Görgey \& Gdt., Zeits. Kryst., v. 48, p. } 652,1910 . \\
\text { Goldschmidt Winkeltabellen. } \\
\text { Do. }\end{array}$ \\
\hline $\begin{array}{l}\epsilon \\
\lambda\end{array}$ & $\begin{array}{l}\overline{1} 12 \\
113 \\
\overline{1} 14\end{array}$ & $\begin{array}{ll}- & \frac{1}{2} \\
- & \frac{3}{3} \\
- & \frac{1}{4}\end{array}$ & $\begin{array}{l}\overline{1} 11 \\
\overline{3} 22 \\
211\end{array}$ & $\begin{array}{ll}- & 1 \\
-3 & 1 \\
-2 & 1\end{array}$ & $\begin{array}{l}\text { Do. } \\
\text { Do. } \\
\text { Do. }\end{array}$ \\
\hline$\stackrel{\kappa}{\omega}$ & $\overline{1} 15$ & $\begin{array}{ll}- & \frac{1}{3} \\
- & \frac{1}{6}\end{array}$ & $\begin{array}{l}\overline{5} 22 \\
311\end{array}$ & $\begin{array}{ll}-\frac{8}{2} & 1 \\
-3 & 1\end{array}$ & $\begin{array}{l}\text { Do. } \\
\text { Do. }\end{array}$ \\
\hline
\end{tabular}


TABLE 1.-Datolite-Continued.

\begin{tabular}{|c|c|c|c|c|c|}
\hline & \multicolumn{2}{|c|}{ Dana orientation. } & \multicolumn{2}{|c|}{$\begin{array}{l}\text { Goldschmidt } \\
\text { orientation. }\end{array}$} & \multirow{2}{*}{ Reference. } \\
\hline & Miller. & $\begin{array}{l}\text { Gold- } \\
\text { schmidt. }\end{array}$ & Miller. & $\begin{array}{l}\text { Gold- } \\
\text { schmidt. }\end{array}$ & \\
\hline b & $\overline{1} 18$ & $-\frac{2}{8}$ & $\overline{4} 11$ & $\begin{array}{ll}-4 & 1\end{array}$ & Görgey \& Gdt., Zeits. Kryst., v. 48, p. 652, 1910. \\
\hline$n_{y}$ & $\overline{1}-1-10$ & $-\frac{1}{10}$ & $\overline{5} 11$ & -51 & Kraus \& Cook, Amer. Journ. Sci., v. 22, p. 21, \\
\hline$\stackrel{B}{M(q)}$ & $\overline{1} 21$ & $\begin{array}{ll}-1 & 2 \\
-\frac{1}{2} & 1\end{array}$ & $\overline{1} 42$ & $\begin{array}{ll}-\frac{1}{2} & 2 \\
-1 & 2\end{array}$ & $\begin{array}{l}\text { Goldschmidt Winkeltabellen. } \\
\text { Whitlock, N. Y. State Mus. Bull., v. } 98 \text {, p. } 19 \text {, } \\
1905 .\end{array}$ \\
\hline $\begin{array}{l}i \\
\alpha \\
C^{\prime}\end{array}$ & $\begin{array}{l}\overline{1} 23 \\
124 \\
125\end{array}$ & $\begin{array}{ll}-\frac{1}{3} & \frac{2}{3} \\
-\frac{1}{1} & \frac{1}{2} \\
-\frac{1}{6} & \frac{2}{6}\end{array}$ & $\begin{array}{l}\overline{3} 42 \\
\overline{2} 21 \\
\overline{5} 42\end{array}$ & $\begin{array}{ll}-\frac{8}{2} & 2 \\
-\frac{5}{2} & 2\end{array}$ & $\begin{array}{l}\text {-Goldschmidt Winkeltabellen. } \\
\text { Do. } \\
\text { Do. }\end{array}$ \\
\hline$\stackrel{\substack{R \\
\mathrm{r}}}{\mathrm{r}}$ & $\begin{array}{l}\overline{1} 26 \\
\overline{1} 31 \\
\overline{1} 32\end{array}$ & $\begin{array}{ll}-\frac{1}{8} & \frac{1}{3} \\
=1 & 3 \\
-\frac{1}{2} & \frac{3}{2}\end{array}$ & $\begin{array}{l}\overline{3} 21 \\
\overline{1} 62 \\
\overline{1} 31\end{array}$ & $\begin{array}{ll}-3 & 2 \\
- & 1 \\
-1 & 3 \\
-1 & 3\end{array}$ & $\begin{array}{l}\text { Görgey \& Gdt., Zeits. Kryst., v. 48, p. 652, } 1910 . \\
\text { Goldschmidt Winkeltabellen. } \\
\text { Do. }\end{array}$ \\
\hline $\begin{array}{l}Y_{1} \\
d \\
\Xi\end{array}$ & $\begin{array}{l}\overline{1} 34 \\
\overline{1} 35 \\
136\end{array}$ & $\begin{array}{ll}-\frac{1}{4} & \frac{3}{4} \\
-\frac{11}{6} & \frac{3}{6} \\
-\frac{1}{6} & \frac{1}{2}\end{array}$ & $\begin{array}{l}\overline{2} 31 \\
\overline{5} 62 \\
\overline{3} 31\end{array}$ & $\begin{array}{ll}-2 & 3 \\
-\frac{5}{2} & 3 \\
- & 3\end{array}$ & $\begin{array}{l}\text { Ungemach, Bull. Soc. Franc., v. } 32, \text { p. } 397,1909 . \\
\text { Do. } \\
\text { Ungemach, Zeits. Kryst., v.49, p.470, } 1911 .\end{array}$ \\
\hline $\begin{array}{l}E \\
V \\
\epsilon^{\prime}\end{array}$ & $\begin{array}{l}\overline{1} 38 \\
\overline{1} 41 \\
\overline{1} 48\end{array}$ & $\begin{array}{ll}-\frac{1}{5} & \frac{3}{8} \\
-1 & 4 \\
-\frac{1}{8} & \frac{1}{2}\end{array}$ & $\begin{array}{l}\overline{4} 31 \\
\overline{1} 82 \\
\overline{4} 41\end{array}$ & $\begin{array}{ll}- & 4 \\
-\frac{1}{2} & 4 \\
- & 4\end{array}$ & $\begin{array}{l}\text { Goldschmidt Winkeltabellen. } \\
\text { Do. } \\
\text { Whitlock, Bull. N. Y. State Mus., v. 98, p. 19,1919. }\end{array}$ \\
\hline $\begin{array}{l}\lambda^{\prime} \\
\mu^{\prime} \\
K\end{array}$ & $\begin{array}{r}\overline{1} 49 \\
\overline{1}-4-10 \\
\overline{1} 58\end{array}$ & $\begin{array}{ll}-\frac{1}{8} & \frac{4}{6} \\
-\frac{1}{20} & \frac{2}{6} \\
-\frac{1}{3} & \frac{5}{8}\end{array}$ & $\begin{array}{l}\overline{9} \\
\overline{5} \\
4 \\
4 \\
51\end{array}$ & $\begin{array}{ll}-\frac{9}{2} & 4 \\
-5 & 4 \\
-4 & 5\end{array}$ & $\begin{array}{l}\text { Do. } \\
\text { Do. } \\
\text { Goldschmidt Winkeltabellen. }\end{array}$ \\
\hline $\begin{array}{l}X \\
G \\
\iota\end{array}$ & $\begin{array}{r}\overline{1} 64 \\
\overline{1}-9-16 \\
\overline{2} 12\end{array}$ & $\begin{array}{ll}-\frac{1}{4} & \frac{3}{2} \\
-\frac{1}{16} & \frac{2}{16} \\
-1 & \frac{1}{2}\end{array}$ & $\begin{array}{l}\overline{2} 61 \\
\overline{8} 91 \\
\overline{1} 12\end{array}$ & $\begin{array}{ll}-2 & 6 \\
-8 & 9 \\
- & \frac{1}{2}\end{array}$ & $\begin{array}{l}\text { Do. } \\
\text { Do. } \\
\text { Do. }\end{array}$ \\
\hline $\begin{array}{l}T \\
\mu_{1}\end{array}$ & $\begin{array}{l}\overline{2} 14 \\
\overline{2} 23 \\
\overline{2} 27\end{array}$ & 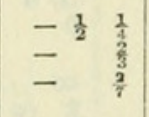 & $\begin{array}{l}\overline{2} 12 \\
\overline{3} 44 \\
744\end{array}$ & $\begin{array}{ll}-1 & \frac{1}{2} \\
=\frac{3}{4} & 1 \\
-\frac{7}{4} & 1\end{array}$ & $\begin{array}{l}\text { Do. } \\
\text { Do. } \\
\text { Slavík \& Fišer, Centralbl. Min, 1903, p. } 229 .\end{array}$ \\
\hline $\begin{array}{l}\pi \\
J \\
O\end{array}$ & $\begin{array}{l}\overline{2} 31 \\
\overline{2} 61 \\
\overline{2} 69\end{array}$ & $\begin{array}{ll}-2 & 3 \\
-2 & 6 \\
-\frac{2}{3} & \frac{2}{3}\end{array}$ & $\begin{array}{r}\overline{1} 64 \\
\overline{1}-12-4 \\
\overline{9}-12-4\end{array}$ & $\begin{array}{ll}- & \frac{1}{4} \\
-\frac{1}{4} & 3 \\
-\frac{9}{4} & 3\end{array}$ & $\begin{array}{l}\text { Goldschmidt Winkeltabellen. } \\
\text { Do. } \\
\text { Do. }\end{array}$ \\
\hline $\begin{array}{l}Y \\
P \\
\text { e }\end{array}$ & $\begin{array}{r}\overline{3} 24 \\
\overline{3} 32 \\
\overline{4}-5-10\end{array}$ & $\begin{array}{ll}-\frac{3}{4} & \frac{1}{2} \\
-\frac{3}{2} & \frac{3}{2} \\
-\frac{1}{2}\end{array}$ & $\begin{array}{l}\overline{2} 23 \\
\overline{1} 33 \\
\overline{5} 54\end{array}$ & $\begin{array}{ll} & \frac{2}{3} \\
=\frac{1}{3} & 1 \\
- & \frac{5}{4}\end{array}$ & $\begin{array}{l}\text { Do. } \\
\text { Görgey \& Gdt., Zeits. Kryst., v. 48, p. 652, } 1910 . \\
\text { Do. }\end{array}$ \\
\hline $\begin{array}{l}k \\
\stackrel{\$}{F} \\
F\end{array}$ & $\begin{array}{r}544 \\
546 \\
5-15-24\end{array}$ & $\begin{array}{ll}-\frac{6}{4} & 1 \\
-\frac{6}{6} & \frac{2}{3} \\
-\frac{8}{24} & \frac{5}{8}\end{array}$ & $\begin{array}{r}\overline{2} 45 \\
\overline{3} 45 \\
\overline{12}-15-5\end{array}$ & $\begin{array}{ll}-\frac{2}{6} & \frac{4}{6} \\
-\frac{3}{5} & \frac{5}{5} \\
-\frac{22}{6} & 3\end{array}$ & $\begin{array}{l}\text { Palache, Zeits. Kryst., v. 47, p. 583, } 1910 . \\
\text { Ungemach, Zeits. Kryst., v. 49, p. 470, } 1911 . \\
\text { Goldschmidt Winkeltabellen. }\end{array}$ \\
\hline$\stackrel{5}{5}$ & $\begin{array}{l}\overline{6} 21 \\
\overline{7} 73 \\
811\end{array}$ & $\begin{array}{ll}-6 & 2 \\
- & \frac{7}{3} \\
-8 & 1\end{array}$ & $\begin{array}{r}\overline{1}-4-12 \\
\overline{3}-14-14 \\
\overline{1}-2-16\end{array}$ & $\begin{array}{ll}-\frac{1}{12} & \frac{1}{3} \\
-\frac{3}{14} & 1 \\
-\frac{1}{16} & \frac{1}{3}\end{array}$ & $\begin{array}{l}\text { Do. } \\
\text { Do. } \\
\text { Ungemach, Zeits. Kryst., v. 49, p. 470, } 1911 .\end{array}$ \\
\hline y & $\overline{9} 11$ & $-9 \quad 1$ & $\overline{1}-2-18$ & $-\frac{1}{18} \frac{1}{8}$ & Görgey \& Gdt., Zeits. Kryst., v. 48, p. 652, 1910. \\
\hline
\end{tabular}

\section{TABLE 2.-Datolite.}

A table of calculated angles for all previously described forms for datolite in the Levy-Dana orientation.

\begin{tabular}{|c|c|c|c|c|c|c|}
\hline Letter. & Miller. & $\begin{array}{l}\text { Gold- } \\
\text { schmidt. }\end{array}$ & $\phi$ & & $\rho$ & \\
\hline & & & 。 & , & 0 & , \\
\hline$a$ & 100 & $\infty \quad 0$ & 90 & 00 & 90 & 00 \\
\hline$b$ & 010 & $0 \propto$ & 0 & 00 & 90 & 00 \\
\hline$\theta$ & 140 & $\infty \quad 4$ & 21 & 30 & 90 & 0 \\
\hline$l$ & 130 & $\infty \quad 3$ & 27 & 43 & 90 & 00 \\
\hline 0 & 120 & $\infty 2$ & 38 & 14 & 90 & 00 \\
\hline
\end{tabular}


TABle 2.-Datolite-Continued.

\begin{tabular}{|c|c|c|c|c|c|c|}
\hline Letter. & Miller. & $\begin{array}{l}\text { Go'd- } \\
\text { schmidt. }\end{array}$ & $\phi$ & & $\rho$ & \\
\hline $\begin{array}{l}\nu \\
m\end{array}$ & $\begin{array}{l}230 \\
340 \\
110\end{array}$ & $\begin{array}{ll}\infty & \frac{3}{2} \\
\infty & \frac{4}{3} \\
& \infty\end{array}$ & $\begin{array}{c}\circ \\
46 \\
49 \\
57\end{array}$ & $\begin{array}{l}\prime \\
25 \\
16 \\
37\end{array}$ & $\begin{array}{c}\circ \\
90 \\
90 \\
90\end{array}$ & $\begin{array}{l}\prime \\
00 \\
00 \\
00\end{array}$ \\
\hline $\begin{array}{l}e \\
s \\
\Delta\end{array}$ & $\begin{array}{l}320 \\
530 \\
210\end{array}$ & $\begin{array}{l}\frac{3}{2} \infty \\
\frac{8}{3} \infty \\
2 \infty\end{array}$ & $\begin{array}{l}67 \\
69 \\
72\end{array}$ & $\begin{array}{l}05 \\
10 \\
24\end{array}$ & $\begin{array}{l}90 \\
90 \\
90\end{array}$ & $\begin{array}{l}00 \\
00 \\
00\end{array}$ \\
\hline$\stackrel{\stackrel{\eta}{S}}{m_{x}(m)}$ & $\begin{array}{l}410 \\
021 \\
011\end{array}$ & $\begin{array}{lr}4 & \infty \\
0 & 2 \\
0 & 1\end{array}$ & $\begin{array}{r}80 \\
0 \\
0\end{array}$ & $\begin{array}{l}59 \\
04 \\
07\end{array}$ & $\begin{array}{l}90 \\
68 \\
51\end{array}$ & $\begin{array}{l}00 \\
27 \\
41\end{array}$ \\
\hline $\begin{array}{c}m_{y} \\
h \\
g\end{array}$ & $\begin{array}{l}067 \\
023 \\
012\end{array}$ & $\begin{array}{ll}0 & \frac{6}{7} \\
0 & \frac{2}{3} \\
0 & \frac{1}{2}\end{array}$ & $\begin{array}{l}0 \\
0 \\
0\end{array}$ & $\begin{array}{l}08 \\
10 \\
14\end{array}$ & $\begin{array}{l}47 \\
40 \\
32\end{array}$ & $\begin{array}{l}19 \\
10 \\
19\end{array}$ \\
\hline $\begin{array}{l}t \\
5 \\
\Omega\end{array}$ & $\begin{array}{l}013 \\
014 \\
018\end{array}$ & $\begin{array}{ll}0 & \frac{1}{3} \\
0 & \frac{1}{4} \\
0 & \frac{1}{8}\end{array}$ & $\begin{array}{l}0 \\
0 \\
0\end{array}$ & $\begin{array}{l}20 \\
27 \\
54\end{array}$ & $\begin{array}{r}22 \\
17 \\
8\end{array}$ & $\begin{array}{l}52 \\
33 \\
59\end{array}$ \\
\hline $\begin{array}{c}m_{2} \\
q \\
p\end{array}$ & $\begin{array}{r}0-1-10 \\
1-0-14 \\
106\end{array}$ & $\begin{array}{r}0 \frac{1}{10} \\
+1_{0}^{14} \\
+\quad 0\end{array}$ & $\begin{array}{l}1 \\
90 \\
90\end{array}$ & $\begin{array}{l}08 \\
00 \\
00\end{array}$ & $\begin{array}{r}7 \\
8 \\
18\end{array}$ & $\begin{array}{l}13 \\
15 \\
31\end{array}$ \\
\hline $\begin{array}{l}u \\
k \\
v\end{array}$ & $\begin{array}{r}104 \\
3-0-10 \\
103\end{array}$ & $\begin{array}{ll}+\quad \frac{1}{4} & 0 \\
+{ }^{3} & 0 \\
+\frac{1}{3} & 0\end{array}$ & $\begin{array}{l}90 \\
90 \\
90\end{array}$ & $\begin{array}{l}00 \\
00 \\
00\end{array}$ & $\begin{array}{l}26 \\
31 \\
33\end{array}$ & $\begin{array}{l}37 \\
01 \\
43\end{array}$ \\
\hline $\begin{array}{l}5 \\
x \\
I\end{array}$ & $\begin{array}{l}308 \\
102 \\
203\end{array}$ & $\begin{array}{l}+\frac{3}{3} 0 \\
+\frac{1}{2} 0 \\
+\frac{2}{3}\end{array}$ & $\begin{array}{l}90 \\
90 \\
90\end{array}$ & $\begin{array}{l}00 \\
00 \\
00\end{array}$ & $\begin{array}{l}36 \\
45 \\
53\end{array}$ & $\begin{array}{l}54 \\
00 \\
07\end{array}$ \\
\hline $\begin{array}{l}f \\
\phi \\
s\end{array}$ & $\begin{array}{l}304 \\
101 \\
302\end{array}$ & $\begin{array}{l}+\frac{3}{4} 0 \\
+10 \\
+\frac{3}{2} 0\end{array}$ & $\begin{array}{l}90 \\
90 \\
90\end{array}$ & $\begin{array}{l}00 \\
09 \\
00\end{array}$ & $\begin{array}{l}56 \\
63 \\
71\end{array}$ & $\begin{array}{l}33 \\
24 \\
18\end{array}$ \\
\hline $\begin{array}{l}\psi \\
j \\
y\end{array}$ & $\begin{array}{l}201 \\
502 \\
601\end{array}$ & $\begin{array}{r}+20 \\
+\quad \frac{5}{2} 0 \\
60\end{array}$ & $\begin{array}{l}90 \\
90 \\
90\end{array}$ & $\begin{array}{l}00 \\
00 \\
00\end{array}$ & $\begin{array}{l}75 \\
78 \\
85\end{array}$ & $\begin{array}{l}56 \\
40 \\
14\end{array}$ \\
\hline $\begin{array}{l}a \\
\xi \\
g\end{array}$ & $\begin{array}{l}\overline{1} 04 \\
\overline{1} 02 \\
\overline{3} 04\end{array}$ & $\begin{array}{ll}-\frac{1}{4} & 0 \\
-\frac{1}{2} & 0 \\
-\frac{2}{3} & 0\end{array}$ & $\begin{array}{l}90 \\
90 \\
90\end{array}$ & $\begin{array}{l}00 \\
00 \\
00\end{array}$ & $\begin{array}{l}26 \\
44 \\
56\end{array}$ & $\begin{array}{l}24 \\
51 \\
12\end{array}$ \\
\hline$\underset{z}{I I}$ & $\begin{array}{l}\overline{1} 01 \\
\overline{3} 02 \\
\overline{2} 01\end{array}$ & $\begin{array}{l}-10 \\
-\frac{3}{2} 0 \\
-20\end{array}$ & $\begin{array}{l}90 \\
90 \\
90\end{array}$ & $\begin{array}{l}00 \\
00 \\
00\end{array}$ & $\begin{array}{l}63 \\
71 \\
75\end{array}$ & $\begin{array}{l}21 \\
18 \\
55\end{array}$ \\
\hline $\begin{array}{c}\boldsymbol{\tau} \\
g_{0}\end{array} \ldots \ldots$ & $\begin{array}{r}702 \\
\overline{11}-0-2 \\
2-15-28\end{array}$ & $\begin{array}{ll}-\frac{7}{2} & 0 \\
-2 \frac{1}{2} & 0 \\
+\frac{1}{14} & \frac{1}{2} \frac{5}{8}\end{array}$ & $\begin{array}{l}90 \\
90 \\
12\end{array}$ & $\begin{array}{l}00 \\
00 \\
04\end{array}$ & $\begin{array}{l}81 \\
84 \\
34\end{array}$ & $\begin{array}{l}51 \\
47 \\
45\end{array}$ \\
\hline $\begin{array}{c}\mathrm{f} \\
k^{\rho}(n)\end{array}$ & $\begin{array}{l}144 \\
148 \\
132\end{array}$ & $\begin{array}{l}+\frac{1}{4} \\
+\frac{1}{8} \\
+\frac{1}{2} \\
+\frac{1}{2}\end{array}$ & $\begin{array}{l}21 \\
21 \\
27\end{array}$ & $\begin{array}{l}36 \\
43 \\
46\end{array}$ & $\begin{array}{l}53 \\
34 \\
65\end{array}$ & $\begin{array}{l}43 \\
15 \\
01\end{array}$ \\
\hline $\begin{array}{c}D \\
Y \\
\Im\end{array}$ & $\begin{array}{l}133 \\
255 \\
362\end{array}$ & 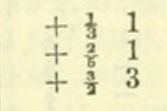 & $\begin{array}{l}27 \\
32 \\
37\end{array}$ & $\begin{array}{l}48 \\
19 \\
38\end{array}$ & $\begin{array}{l}55 \\
56 \\
78\end{array}$ & $\begin{array}{l}04 \\
16 \\
29\end{array}$ \\
\hline $\begin{array}{l}R \\
\beta \\
d .\end{array}$ & $\begin{array}{l}241 \\
121 \\
364\end{array}$ & $\begin{array}{l}+24 \\
+12 \\
+\frac{3}{4}\end{array}$ & $\begin{array}{l}38 \\
38 \\
38\end{array}$ & $\begin{array}{l}14 \\
15 \\
18\end{array}$ & $\begin{array}{l}81 \\
72 \\
67\end{array}$ & $\begin{array}{l}11 \\
14 \\
32\end{array}$ \\
\hline $\begin{array}{l}Q \\
U \\
\gamma\end{array}$ & $\begin{array}{l}122 \\
123 \\
124\end{array}$ & 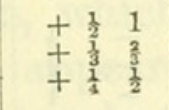 & $\begin{array}{l}38 \\
38 \\
38\end{array}$ & $\begin{array}{l}19 \\
21 \\
23\end{array}$ & $\begin{array}{l}58 \\
47 \\
38\end{array}$ & $\begin{array}{l}12 \\
06 \\
55\end{array}$ \\
\hline $\begin{array}{l}M^{1} \\
k \cdot \\
\Re\end{array}$ & $\begin{array}{l}231 \\
578 \\
454\end{array}$ & $\begin{array}{l}+23 \\
+\frac{5}{8} \\
+1 \frac{5}{4}\end{array}$ & $\begin{array}{l}46 \\
48 \\
51\end{array}$ & $\begin{array}{l}26 \\
27 \\
36\end{array}$ & $\begin{array}{l}79 \\
59 \\
68\end{array}$ & $\begin{array}{l}43 \\
05 \\
34\end{array}$ \\
\hline $\begin{array}{l}\delta \\
n \\
\Lambda\end{array}$ & $\begin{array}{l}221 \\
111 \\
112\end{array}$ & $\begin{array}{l}+\quad 2 \\
+\quad 1 \\
+\quad 2\end{array}$ & $\begin{array}{l}57 \\
57 \\
57\end{array}$ & $\begin{array}{l}37 \\
38 \\
40\end{array}$ & $\begin{array}{l}78 \\
67 \\
49\end{array}$ & $\begin{array}{l}03 \\
04 \\
48\end{array}$ \\
\hline $\begin{array}{l}L \\
W \\
1\end{array}$ & $\begin{array}{l}113 \\
114 \\
115\end{array}$ & $\begin{array}{l}+\quad \frac{1}{3} \\
+ \\
+\quad \frac{1}{4} \\
\end{array}$ & $\begin{array}{l}57 \\
57 \\
57\end{array}$ & $\begin{array}{l}42 \\
44 \\
46\end{array}$ & $\begin{array}{l}38 \\
30 \\
25\end{array}$ & $\begin{array}{l}18 \\
40 \\
24\end{array}$ \\
\hline $\begin{array}{c}Z \\
\ddot{2} \\
\ddot{q}\end{array}$ & $\begin{array}{r}116 \\
1-1-18 \\
763\end{array}$ & $\begin{array}{l}+\quad \frac{1}{6} \\
+\quad r^{1 / g} \\
+\frac{7}{2}\end{array}$ & $\begin{array}{l}57 \\
58 \\
61\end{array}$ & $\begin{array}{l}48 \\
11 \\
29\end{array}$ & $\begin{array}{r}21 \\
7 \\
79\end{array}$ & $\begin{array}{l}36 \\
36 \\
19\end{array}$ \\
\hline
\end{tabular}


TABLe 2.-Datolite-Continued.

\begin{tabular}{|c|c|c|c|c|c|c|}
\hline Letter. & Miller. & $\begin{array}{l}\text { Gold- } \\
\text { schmidt. }\end{array}$ & $\phi$ & & & \\
\hline $\begin{array}{l}\stackrel{F}{5} \\
N \\
w\end{array}$ & $\begin{array}{l}548 \\
322 \\
324\end{array}$ & 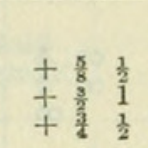 & $\begin{array}{c}\circ \\
63 \\
67 \\
67\end{array}$ & $\begin{array}{l}\text {, } \\
08 \\
05 \\
06\end{array}$ & & $\begin{array}{l}, \\
28 \\
54 \\
26\end{array}$ \\
\hline $\begin{array}{l}x \\
D \\
\vartheta\end{array}$ & $\begin{array}{l}534 \\
211 \\
212\end{array}$ & $\begin{array}{l}+\frac{5}{4} \frac{3}{4} \\
+2 \\
+1 \frac{1}{2}\end{array}$ & $\begin{array}{l}69 \\
72 \\
72\end{array}$ & $\begin{array}{l}11 \\
24 \\
25\end{array}$ & & $\begin{array}{l}28 \\
34 \\
29\end{array}$ \\
\hline $\begin{array}{l}\mathfrak{B} \\
\mathfrak{b} \\
\mathfrak{w}\end{array}$ & $\begin{array}{l}421 \\
213 \\
215\end{array}$ & $\begin{array}{r}+42 \\
+\quad 3 \\
+\quad \frac{2}{3} \\
+\frac{3}{6}\end{array}$ & $\begin{array}{l}72 \\
72 \\
72\end{array}$ & $\begin{array}{l}26 \\
26 \\
27\end{array}$ & & $\begin{array}{l}11 \\
25 \\
01\end{array}$ \\
\hline $\begin{array}{c}A \\
J_{1} \\
q\end{array}$ & $\begin{array}{l}216 \\
311 \\
312\end{array}$ & $\begin{array}{l}+\frac{1}{3} \frac{1}{6} \\
+3 \\
+3 \frac{3}{2} \\
+\frac{3}{2}\end{array}$ & $\begin{array}{l}72 \\
78 \\
78\end{array}$ & $\begin{array}{l}27 \\
04 \\
04\end{array}$ & & $\begin{array}{l}00 \\
43 \\
55\end{array}$ \\
\hline $\begin{array}{l}\stackrel{g}{B} \cdot \\
\Gamma \\
\kappa_{2}\end{array}$ & $\begin{array}{l}313 \\
314 \\
722\end{array}$ & $\begin{array}{ll}+1 & \frac{1}{3} \\
+\frac{3}{4} & \frac{1}{4} \\
+\frac{7}{2} & 1\end{array}$ & $\begin{array}{l}78 \\
78 \\
79\end{array}$ & $\begin{array}{l}04 \\
05 \\
44\end{array}$ & & $\begin{array}{l}54 \\
52 \\
59\end{array}$ \\
\hline $\begin{array}{l}I \\
\Psi \\
G\end{array}$ & $\begin{array}{r}412 \\
414 \\
\overline{1}-9-16\end{array}$ & $\begin{array}{l}+2 \frac{1}{2} \\
\pm 12 \frac{1}{4} \\
-16 \frac{3}{16}\end{array}$ & $\begin{array}{r}80 \\
81 \\
9\end{array}$ & $\begin{array}{l}47 \\
00 \\
44\end{array}$ & & $\begin{array}{l}06 \\
40 \\
52\end{array}$ \\
\hline $\begin{array}{l}X \\
K \\
\mu^{\prime}\end{array}$ & $\begin{array}{r}164 \\
\overline{1} 158 \\
\overline{1}-4-10\end{array}$ & $\begin{array}{ll}-\frac{1}{2} & \frac{3}{2} \\
\frac{2}{8} & \frac{8}{8} \\
-\frac{2}{10} & \frac{2}{6}\end{array}$ & $\begin{array}{l}14 \\
17 \\
21\end{array}$ & $\begin{array}{l}39 \\
20 \\
16\end{array}$ & & $\begin{array}{l}00 \\
39 \\
30\end{array}$ \\
\hline $\begin{array}{l}\lambda^{\prime} \\
\epsilon^{\prime} \\
V\end{array}$ & $\begin{array}{l}\overline{1} 49 \\
\overline{1} 48 \\
\overline{1} 41\end{array}$ & 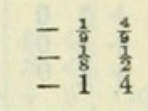 & $\begin{array}{l}21 \\
21 \\
21\end{array}$ & $\begin{array}{l}18 \\
19 \\
29\end{array}$ & & $\begin{array}{l}07 \\
11 \\
35\end{array}$ \\
\hline$\frac{E}{\mathbb{Z}}$ & $\begin{array}{l}\overline{1} 38 \\
\overline{1} 36 \\
\overline{1} 35\end{array}$ & $\begin{array}{ll}-\frac{1}{8} & \frac{3}{3} \\
=\frac{8}{6} & \frac{1}{2} \\
-\frac{1}{6} & \frac{3}{8}\end{array}$ & $\begin{array}{l}27 \\
27 \\
27\end{array}$ & $\begin{array}{l}29 \\
32 \\
34\end{array}$ & & $\begin{array}{l}09 \\
31 \\
35\end{array}$ \\
\hline $\begin{array}{l}F \\
O \\
Y_{1}\end{array}$ & $\begin{array}{r}5-15-24 \\
\overline{2} 69 \\
134\end{array}$ & $\begin{array}{ll}-\frac{5}{24} & \frac{5}{8} \\
=\frac{2}{5} & \frac{2}{3} \\
-\frac{1}{2} & \frac{3}{4}\end{array}$ & $\begin{array}{l}27 \\
27 \\
27\end{array}$ & $\begin{array}{l}34 \\
36 \\
36\end{array}$ & & $\begin{array}{l}45 \\
36 \\
58\end{array}$ \\
\hline $\begin{array}{l}{ }_{H}^{\mathrm{r}} \\
{ }_{J}\end{array}$ & $\begin{array}{l}\overline{1} 32 \\
\overline{1} 31 \\
\overline{2} 61\end{array}$ & $\begin{array}{ll}-\frac{1}{2} & \frac{3}{3} \\
-1 & 3 \\
-2 & 6\end{array}$ & $\begin{array}{l}27 \\
27 \\
27\end{array}$ & $\begin{array}{l}40 \\
41 \\
42\end{array}$ & & $\begin{array}{l}59 \\
53 \\
21\end{array}$ \\
\hline $\begin{array}{l}\Re \\
C \\
\alpha\end{array}$ & $\begin{array}{l}\overline{1} 26 \\
\overline{1} 25 \\
\overline{1} 24\end{array}$ & 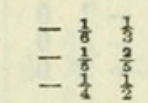 & $\begin{array}{l}38 \\
38 \\
38\end{array}$ & $\begin{array}{l}02 \\
04 \\
06\end{array}$ & & $\begin{array}{l}19 \\
45 \\
49\end{array}$ \\
\hline$M_{B}^{i}(\mathrm{q})$ & $\begin{array}{l}\overline{1} 23 \\
\overline{1} 22 \\
\overline{1} 21\end{array}$ & $\begin{array}{ll}-\frac{1}{3} & \frac{2}{3} \\
-\frac{1}{2} & 1 \\
-1 & 1\end{array}$ & $\begin{array}{l}38 \\
38 \\
38\end{array}$ & $\begin{array}{l}08 \\
10 \\
12\end{array}$ & & $\begin{array}{l}00 \\
09 \\
46\end{array}$ \\
\hline $\begin{array}{l}\text { a } \\
\stackrel{e}{n_{y}}\end{array}$ & $\begin{array}{r}\overline{2} 31 \\
\overline{4}-5-10 \\
\overline{1}-1-10\end{array}$ & $\begin{array}{l}=23 \\
=\frac{2}{8} \\
=\frac{1}{2} \\
=\quad \frac{2}{50}\end{array}$ & $\begin{array}{l}46 \\
51 \\
57\end{array}$ & $\begin{array}{l}24 \\
30 \\
17\end{array}$ & & $\begin{array}{l}42 \\
28 \\
11\end{array}$ \\
\hline $\begin{array}{l}\mathfrak{b} \\
\omega \\
\kappa\end{array}$ & $\begin{array}{l}\overline{1} 18 \\
\overline{1} 16 \\
\overline{1} 15\end{array}$ & $\begin{array}{l}=\frac{1}{8} \\
\overline{\frac{1}{5}} \\
\frac{7}{8}\end{array}$ & $\begin{array}{l}57 \\
57 \\
57\end{array}$ & $\begin{array}{l}21 \\
24 \\
27\end{array}$ & & $\begin{array}{l}58 \\
23 \\
12\end{array}$ \\
\hline $\begin{array}{l}\mu \\
\mu_{1} \\
\lambda\end{array}$ & $\begin{array}{l}\overline{1} 14 \\
\overline{2} 27 \\
\overline{1} 13\end{array}$ & $\begin{array}{l}=\frac{1}{2} \\
\overline{\frac{2}{3}}\end{array}$ & $\begin{array}{l}57 \\
57 \\
57\end{array}$ & $\begin{array}{l}29 \\
30 \\
31\end{array}$ & & $\begin{array}{l}29 \\
56 \\
09\end{array}$ \\
\hline $\begin{array}{l}\epsilon \\
\delta\end{array}$ & $\begin{array}{l}\overline{1} 12 \\
\overline{2} 23 \\
\overline{1} 11\end{array}$ & $\begin{array}{l}\overline{\frac{1}{2}} \\
\overline{3} \\
\overline{3}\end{array}$ & $\begin{array}{l}57 \\
57 \\
57\end{array}$ & $\begin{array}{l}33 \\
34 \\
34\end{array}$ & & $\begin{array}{l}42 \\
33 \\
03\end{array}$ \\
\hline $\begin{array}{l}P \\
\text { (3) } \\
\Phi\end{array}$ & $\begin{array}{l}332 \\
7732 \\
546\end{array}$ & $\begin{array}{l}\bar{y} \\
\bar{Z} \\
\overline{8}\end{array}$ & $\begin{array}{l}57 \\
57 \\
63\end{array}$ & $\begin{array}{l}35 \\
36 \\
04\end{array}$ & & $\begin{array}{l}14 \\
43 \\
46\end{array}$ \\
\hline 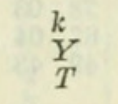 & $\begin{array}{l}\frac{5}{3} 44 \\
\frac{3}{214}\end{array}$ & 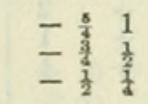 & $\begin{array}{l}63 \\
67 \\
72\end{array}$ & $\begin{array}{l}04 \\
03 \\
22\end{array}$ & & $\begin{array}{l}19 \\
49 \\
14\end{array}$ \\
\hline$\grave{\iota}$ & $\begin{array}{l}\frac{2}{6} 12 \\
\frac{6}{811}\end{array}$ & $\begin{array}{ll}-1 & \frac{1}{2} \\
=6 & 2 \\
-8 & 1\end{array}$ & $\begin{array}{l}72 \\
78 \\
85\end{array}$ & $\begin{array}{l}23 \\
04 \\
28\end{array}$ & & $\begin{array}{l}26 \\
20 \\
26\end{array}$ \\
\hline y & $\overline{9} 11$ & $\begin{array}{ll}-9 & 1\end{array}$ & 85 & 58 & 86 & 49 \\
\hline
\end{tabular}


GENERAL FEATURES.

The datolite of the Westfield specimens occurs commonly as thick crusts of comparatively large crystals, lining open spaces in the basaltic rock, although rather dense veins and masses of granular datolite occur occasionally. There appears to be but one generation of the mineral and no other mineral is contemporaneous with it. The datolite in all parts of the area appears to have been deposited at the same period and under very similar conditions as regards temperature, pressure, and composition of solutions. The crystals vary from 1 millimeter to approximately 10 centimeters in diameter, the average diameter being around 1 centimeter. The crystals of

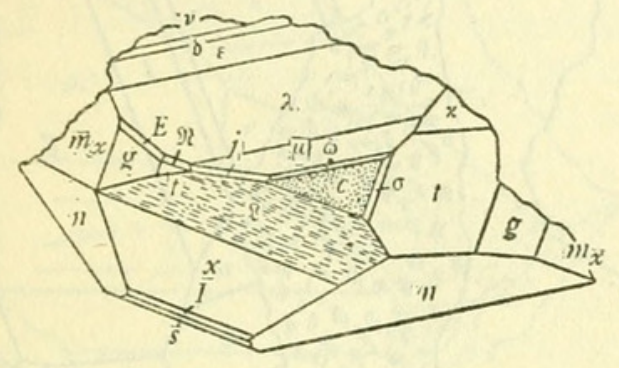

13
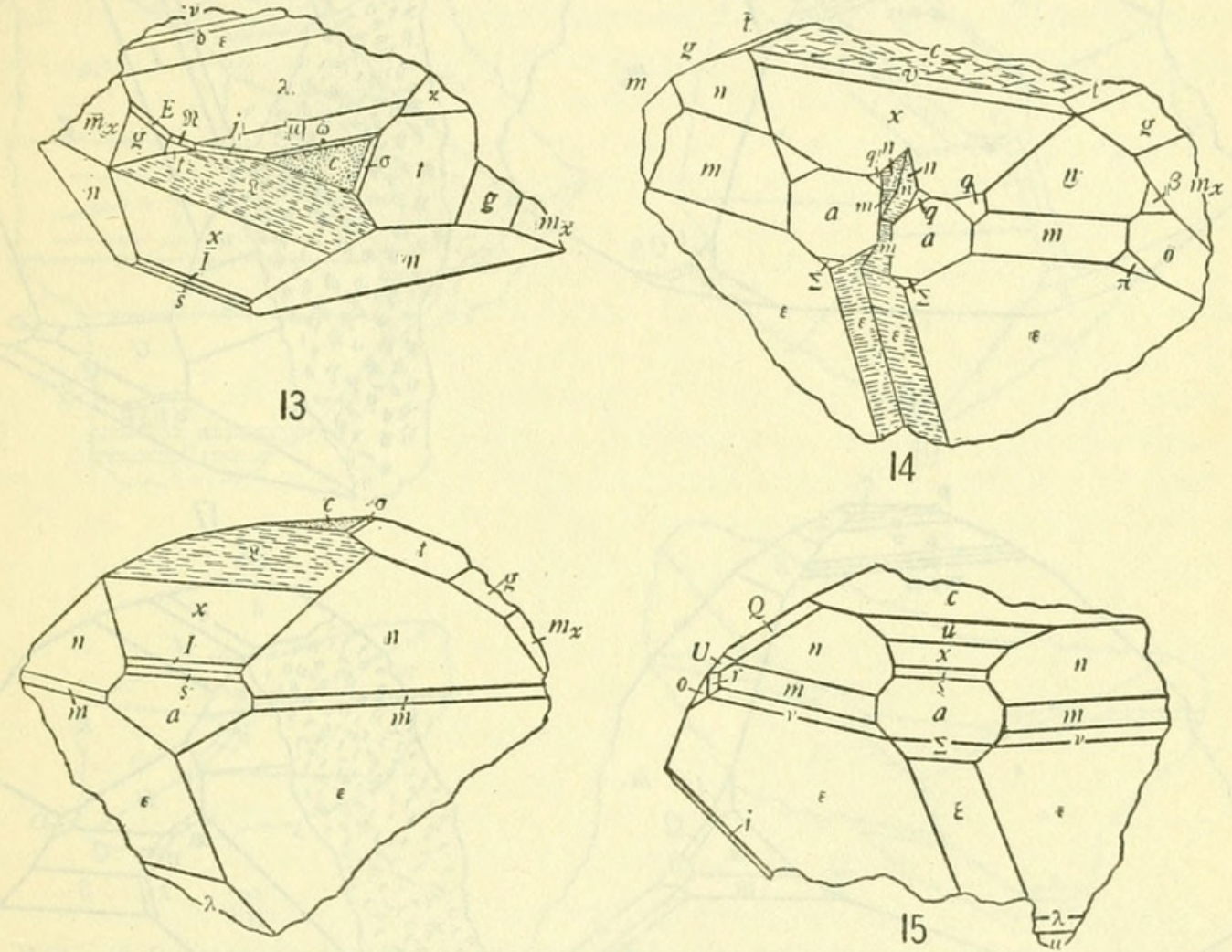

Figs. 13-15.-13, ORTHOGRAPHIC AND CLINOGRAPHIC PROJECTIONS OF CRYSTAL B5, SHOWING UNSYMMETRICAL DEVELOPMENT, ETCHING OF $c$ (001), AND STRIATION OF $\&$ (205); ALSO THE RARE AND NEW FORMS $s(302), I(203), \omega(\overline{1} 16), \mathrm{N}(\overline{1} 26), E(\overline{1} 38)$, AND $j_{1}$ (5.6.30). 14, CLINOGRAPHIC PROJECTION OF CRYSTAL B11, SHOWING PARALLEL GROWTH WITH REENTRANT ANGLE RESEMBLING TWINNING. ALSO SHOWS CHARACTERISTIC "RULING" OF THE BASAL PINACOID. 15, CLINOGRAPHIC PROJECTION OF CR TSTAL 39 SHOWING PROMINENT DEVELOPMENT OF $\Sigma(\overline{3} 02)$ AND $\xi(\overline{1} 02)$.

any given cavity or specimen, which are usually of approximately the same order of magnitude, appear to have grown simultaneously, very closely crowded together, and at about the same rate, and only rarely has an individual outstripped its neighbors and assumed a large size at their expense. The close crowding of the crystals has been almost universal, and they are consequently not nearly so well developed as would have been possible had they been more sparsely distributed over the base to which they are attached. Only the free surfaces projecting into the open portion of the cavity 
are bounded by crystal planes. In many ways the thicker crusts of datolite resemble the quartz combs of veins. They differ, however, in that each crystal repelled those adjoining it and preserved its individuality while growing upward, hemmed in on all sides, and instead of interlocking firmly in the crusts, the masses of crystals can often be separated with the fingers. Normally mutual interference

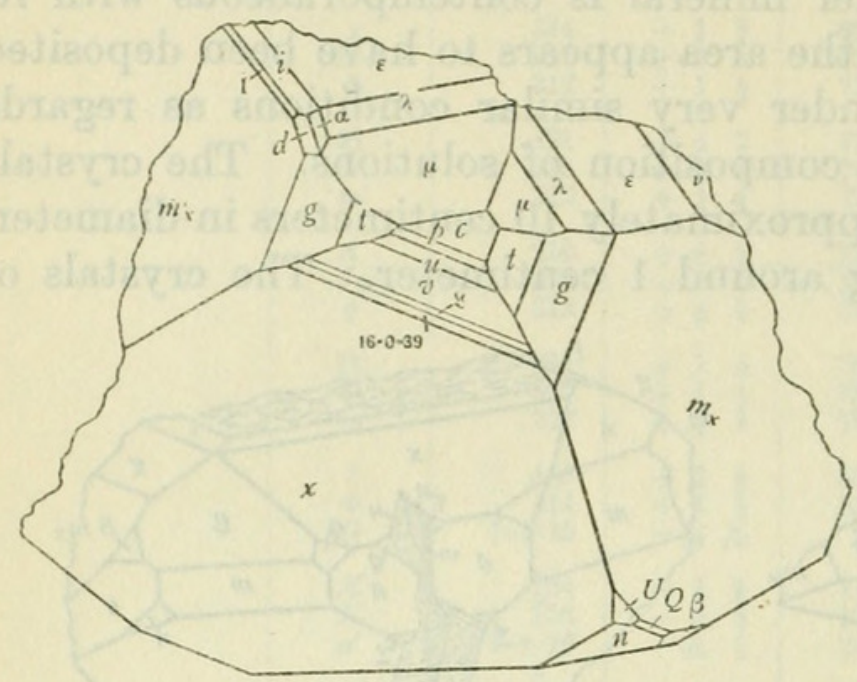

16

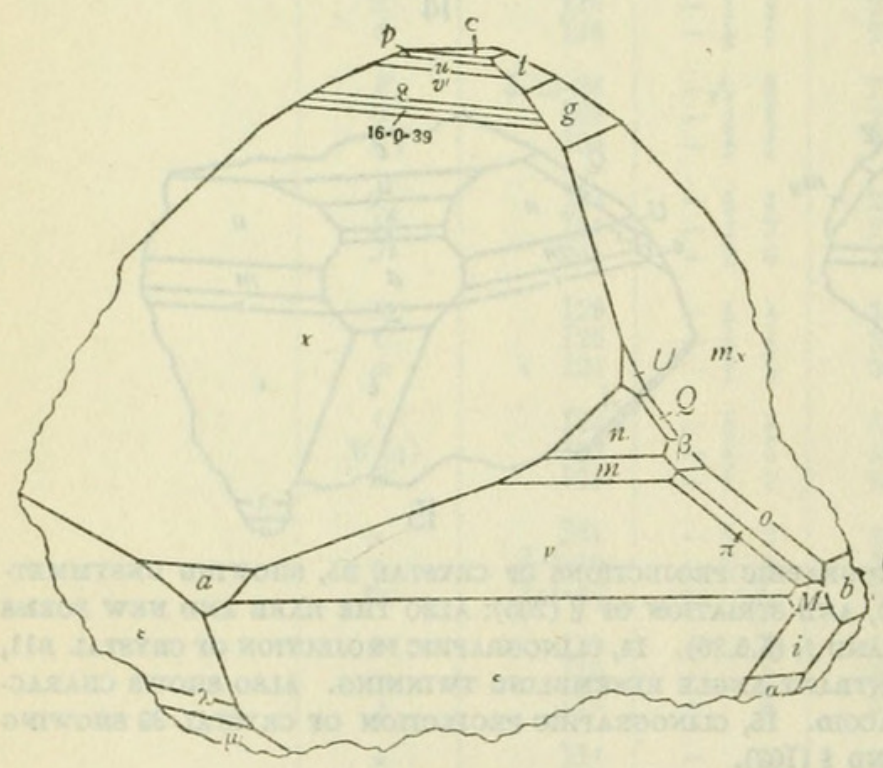

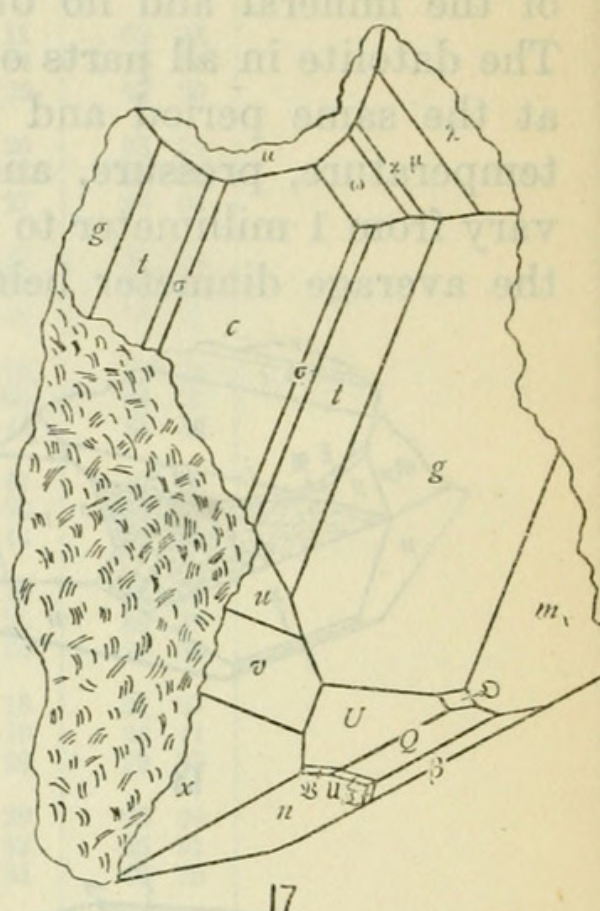

17

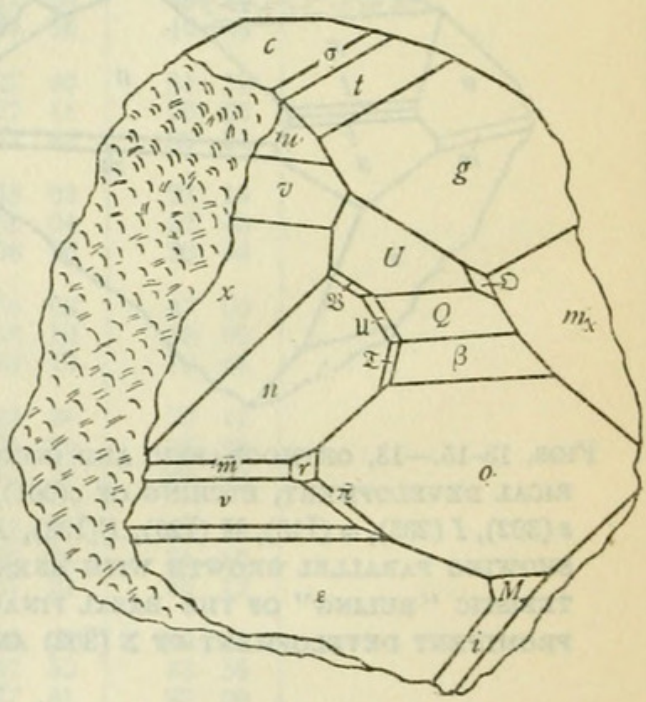

Figs. 16-17.-16, ORTHOGRAPHIC AND CLINOGRAPHIC PROJECTIONS OF CRYSTAL 10 SHOWING FORM AND DEVELOPMENT, ALSO THE FORMS I (167) $\&$ (205) AND THE VICINAL FORM (16.0.39). 17, ORTHOGRAPHIC AND CLINOGRAPHIC PROJECTIONS OF CRYSTAL 51 SHOWING THE NEW FORMS $\mathfrak{I}(343), \mathfrak{U}(344), \mathfrak{B}$ (345) AND $\mathcal{D}(134)$.

seems to have resulted in pressure exerted nearly equally in all directions, so that many crystals are now more or less columnar, with the termination only bounded by crystal planes. The surfaces of contact with adjoining crystals show peculiar striations, doubtless resulting from oscillation exerted by growth pressure and following definite 
mathematical laws. Such striated contact surfaces are well shown in the photograph (pl. 104). In less frequent instances the growth tendency was exerted more strongly in one direction and resulted in sheaves of platy crystals, grown together in more or less parallel position, the plane of contact in many examples being approximately parallel to $\xi(\overline{1} 02)$.

The crystals vary from transparent to almost opaque. The transparent crystals when first exposed to light are rather deep yellow green in color, but the color fades gradually on exposure to light
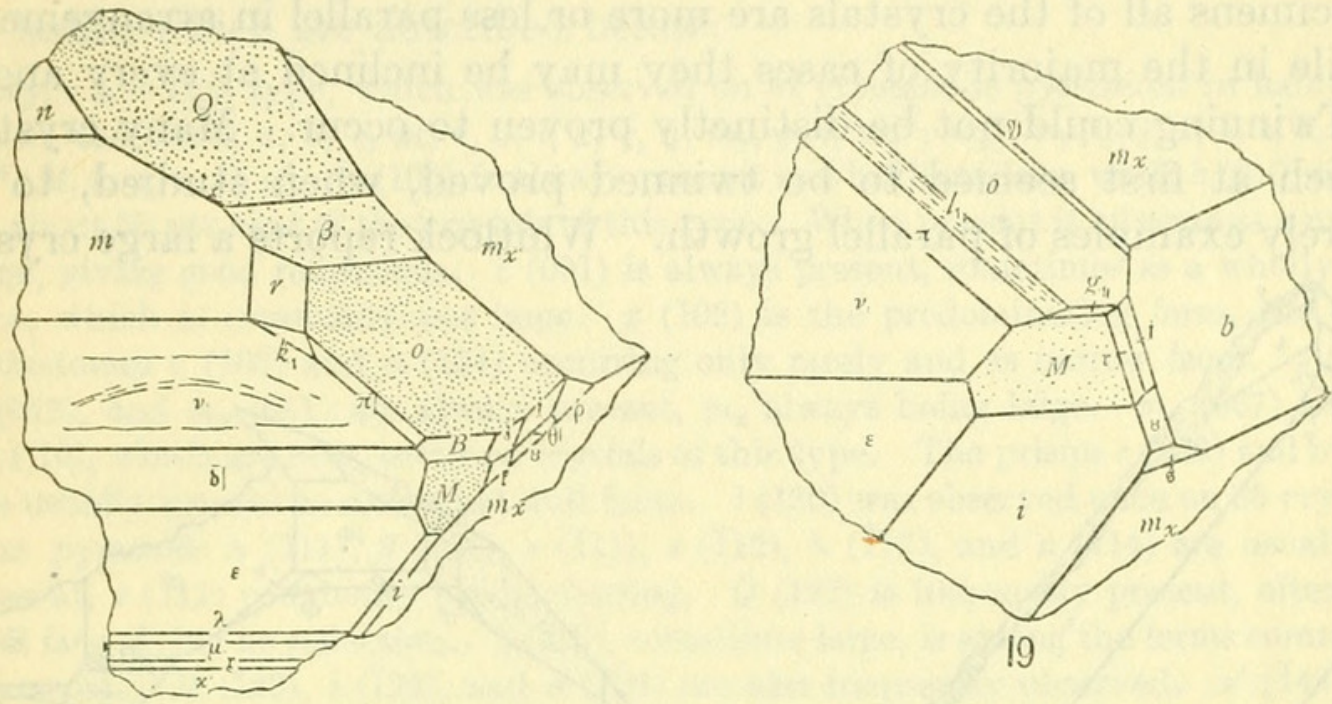

18

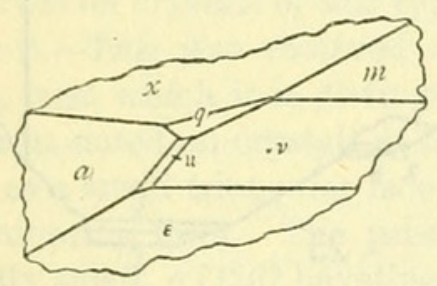

20

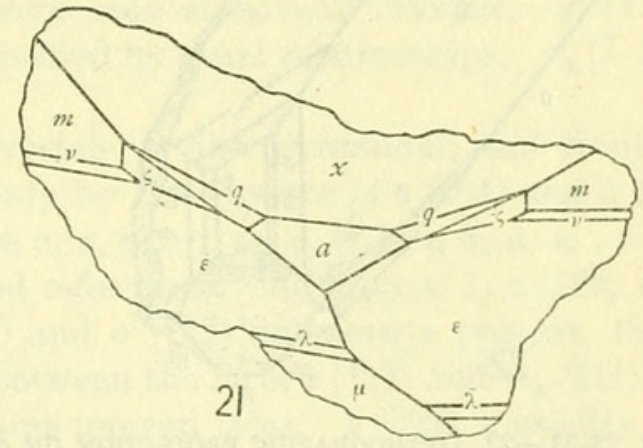

Figs. 18-21.-18, Clinographic detail of CRystal 41 showing the New Forms $k_{1}$ (794), i (142), $\mathfrak{f}$ (143),

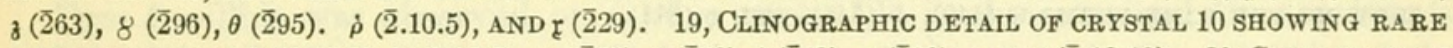
AND NEW FORMS $\mathfrak{y}$ (6.15.2), $l_{1}(9.16 .2), g_{1}(\overline{2} 62), r(\overline{2} 32), \mathrm{i}(\overline{2} 42), \gamma(\overline{2} 96)$, AND $\&(\overline{2} .12 .10)$. 20, CLINOGRAPHIC DETAIL OF PORTION OF CRYSTAL 44 SHOWING NEW FORM u (211). 21, ClINOGRAPHIC PROJECTION OF CRYSTAL 43 SHOWING UNUSUAL FORM s (530).

until they become almost colorless. The opaque crystals are pure white in color and possess a peculiar porcellanous appearance.

Cleavage was not observed, unless some faint rifts, which are parallel to the pinacoid $a(100)$ and give iridescent reflections, indicate a very obscure cleavage parallel to this plane. Whitlock describes his crystals as showing distinct cleavage parallel to $a$ (100) and parallel to $c(001)$ somewhat less perfect. The present observations do not confirm these results. Several large transparent crystals were heated to various temperatures and chilled with water in an attempt to develop cleavage, but the crystals became filled with ramifying 
cracks, like those developed in glass, by the same treatment and show no indication of cleavage.

The crystals may be attached by any part, but from the development of those studied it appears that a majority of them are attached by the negative end of the $a$ axis, the front of the crystal being completely developed, while the rear is bounded by fracture or interference surfaces. This frequently requires that the crystal be set up in two positions, top and bottom, on the 2-circle goniometer in order that all the forms may be measured in the Dana position. In some specimens all of the crystals are more or less parallel in arrangement, while in the majority of cases they may be inclined at every angle.

Twinning could not be distinctly proven to occur. Many crystals which at first seemed to be twinned proved, when studied, to be merely examples of parallel growth. Whitlock reports a large crystal
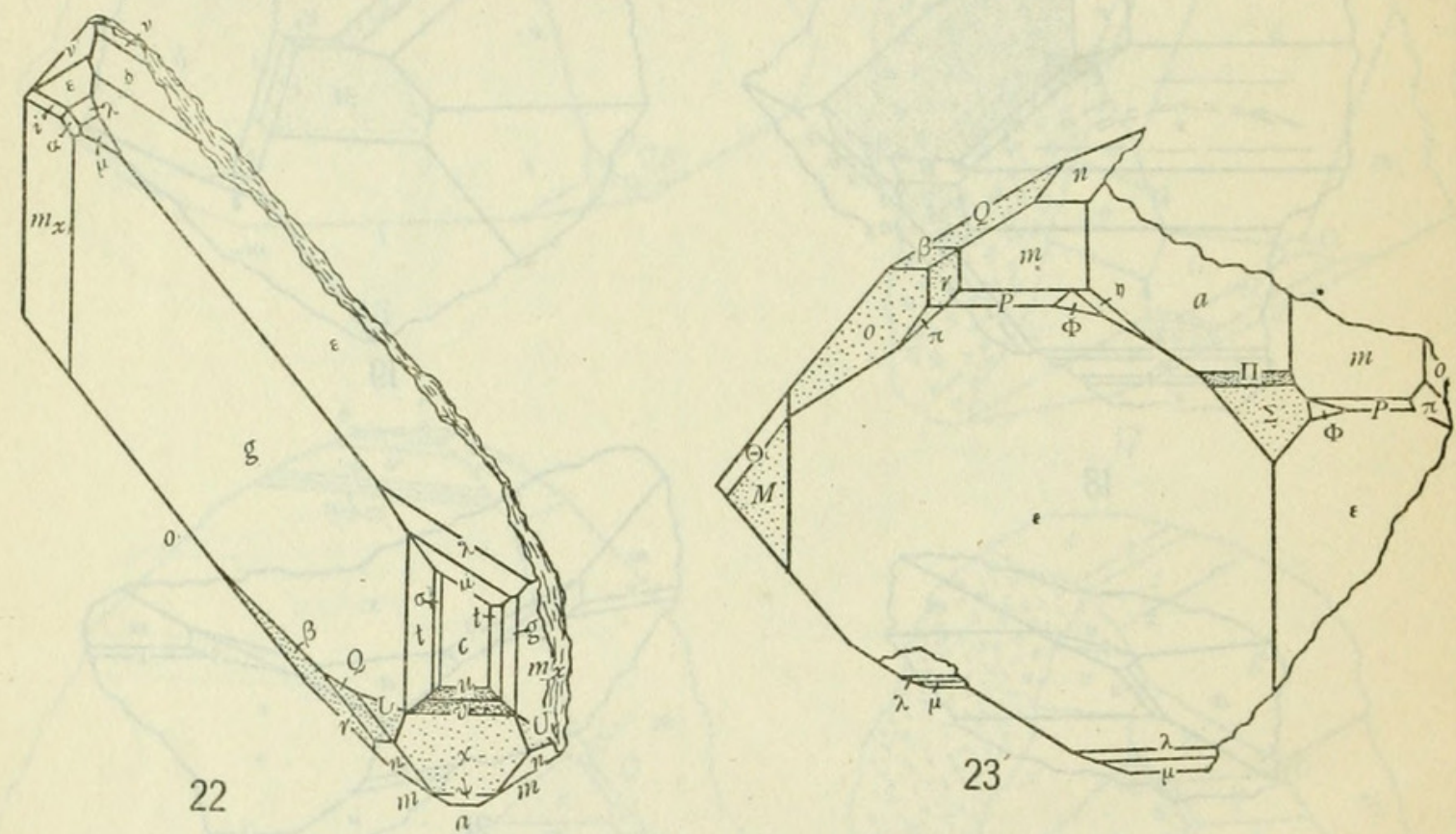

Figs. 22-23.-22, ORTHOGRAPHIC PROJECTION ON $c$ (001) OF CRYSTAL 65 SHOWING PECULIAR DistoRTION

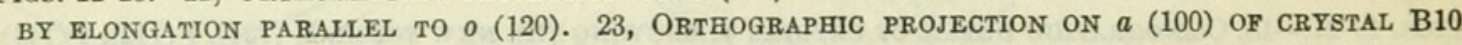
SHOWING THE RARE FORMS $\theta(140), \Phi(\overline{5} 46)$, AND y $(\overline{8} 11)$.

from Westfield as a penetration twin parallel to $a$ (100), having $c$ for the twinning axis. This is the only reported occurrence of twinning in datolite.

Parallel growth is very common and characteristic, nearly every crystal being composite and made up of two or more individuals in parallel position. Although made up of more than one crystal these are united in a peculiar manner, some planes being common to both individuals, which merge without any trace of even a suture to show where they are joined, although sutures frequently occur. These parallel growths occur in great variety and are sometimes very striking in appearance and resemble twins. Figure 14 is drawn to show a very typical example, and the "step" growth is well shown 
in the photographs, plates 104 and 105 , especially by the large crystal in the center of the specimen illustrated in the plate 105.

\section{HABIT.}

Whitlock apparently did not distinguish more than one type in the crystals examined by him. From his description and figures it is obvious that these were essentially like those of type 1 of Kraus and Cook described below.

Kraus and Cook distinguish four types differentiated by variation in habit, which are described below:

Type 1.-This type, which was observed on 34 crystals, is pyramidal in habit and shows the forms $a, b, c, m, r, o, l, x, v, u, m_{\mathrm{x}}, g, t, m_{\mathrm{y}}{ }^{*}, m_{\mathrm{z}}{ }^{*}, n, \beta, Q, \nu, \delta, \epsilon, \lambda, \mu, \kappa$, $n_{\mathbf{z}}^{*}, M, i, \alpha, \pi, \epsilon^{\prime}, \mu^{\prime} . \quad a(100)$ is always present as a brilliant face, while $b(010)$ occurs on about 50 per cent of the crystals of this type. When present it appears as a narrow edge, giving good reflections. $c(001)$ is always present, sometimes as a wholly dull face, which is commonly not large. $x(102)$ is the predominating form, the other orthodomes $v$ (103) and $u$ (104) occurring only rarely and as narrow faces. $t(013)$, $g(012)$, and $m_{\mathbf{x}}(011)$ are always present, $m_{\mathbf{x}}$ always being large. $m_{\mathbf{y}}(067)$ and $m_{\mathbf{z}}$ (0.1.10), which are new, occur on crystals of this type. The prisms $r(230)$ and $o(120)$ are usually present as somewhat dull faces. $l(130)$ was observed once on 35 crystals. The pyramids $n$ (111), $\beta(121), \nu(\overline{1} 11), \epsilon(\overline{1} 12), \lambda(\overline{1} 13)$, and $\mu(\overline{1} 14)$ are usually all present, $\nu(\overline{1} 11)$ commonly predominating. $Q(122)$ is frequently present, often as a dull face giving no reflection. D ( 223$)$, sometimes large, is among the forms commonly observed. $\quad M(\overline{1} 22), i(\overline{1} 23)$, and $\alpha(\overline{1} 24)$ are also frequently observed. $\epsilon^{\prime}(\overline{1} 48)$ and $\mu^{\prime}(\overline{1} .4 .10)$, first described by Whitlock, were seen on several crystals. $\mu^{\prime}(1.4 .10)$ gave very good readings but $\epsilon^{\prime}(\overline{1} 48)$ was identified by zonal relationships. $n_{\mathrm{z}}(\overline{1}-1-10)$ also occurs on crystals of this type.

Type 2.-This was observed on seven crystals, is also pyramidal, and similar to type 1 , from which it is distinguished mainly by the absence of $c(001)$ and $b(010)$. The forms noted on crystals of this type are $a, x, m_{x}, g, m, o, n, \delta, \epsilon, \lambda, \mu, \nu . \quad a(100)$ occurs as a small triangular face giving good reflections. As in type $1, x(102)$ is the predominating form. The prisms $m$ (110) and $o$ (102) are always present, though generally small, $o(120)$ beveling the edge between the faces $\nu(\overline{1} 11)$ and $m_{\mathrm{x}}(011)$. Of the pyramids $\epsilon(\overline{1} 12)$ and $\lambda(\overline{1} 13)$ present large uneven faces. $\delta(\overline{2} 23)$ is usually dull. The other pyramids occur as very small faces.

Type 3.-This was observed on four crystals. It is characterized by a prismatic habit with $a(100)$ prominent. All forms are well developed, the following being noted: $a, b, c, x, \xi, m_{\mathbf{x}}, g, t, m, n, \nu, \epsilon, \lambda, \mu$. All forms except $\nu$ (1111) and $\xi(\overline{1} 02)$ are brilliant, giving good reflections. $\nu(\overline{1} 11)$ occurs as a dull form and $\xi(\overline{1} 02)$, in addition to being dull, was so small that it could only be identified by zonal relationships.

Type 4.- This was observed on 2 crystals, is tabular in habit, the base $c(001)$ being prominent. The forms noted on crystals of this type are $a, b, c, m, m_{\mathrm{x}}, g, t, x$, $v, n, \nu$, and $\epsilon$. Of the clinodomes $g(012)$ predominates, $m_{x}(011)$ and $g(013)$ being comparatively narrow faces. The orthodomes $x(102)$ and $v(103)$ are both dull forms.

Ungemach writes that there are, both on his crystals and on those examined by Görgey and Goldschmidt, two well-defined types distinguished according to the development of certain typical forms rather than upon habit which is subject to great variation:

Very characteristic for distinguishing between these are the forms of the orthodome zone. In the first type there are no steeper domes than $x(102)$ and $\xi(102)$. There 27177-21-Proc.N.M.vol.59-32 
occur here mostly $v(103)$ with or without $\mathfrak{S}(308)$ and $k:(3.0 .10)$, which may replace $v$ (103). These three forms are always lacking in type 2 crystals, which often show the typical rounded form $\psi(201)$ and the negative II (101) and $\Sigma(\overline{3} 02)$. Another important feature is the etching on these forms. On type 1 all the negative domes are dull but give fairly good though faint signals on the goniometer, while on type 2 crystals $v$ (103) and $x(102)$ are completely lacking in reflection. The form $\nu(\overline{1} 11)$ is a characteristic form of type 1 , while on crystals of type 2 it is replaced by $P(\overline{3} 32)$ as brilliant faces. Finally, only on type 2 crystals occur $q(312)$ and $\Gamma(314)$ with the subordinate forms controlled by this interesting group, which includes $\mathfrak{y}(\overline{8} 11)$ and $\Phi(\overline{5} 46)$. The forms which are characteristic of the two types are as follows:

$\begin{array}{cc}\text { Type 1. } & \text { Type 2. } \\ & \psi(201) \\ k:(3.0 .10) & y^{\cdot}(601) \\ v(103) & j(502) \\ \mathfrak{S}(308) & \Sigma(\overline{3} 02) \\ \nu(\overline{1} 11) & \Pi(\overline{1} 01) \\ & P(\overline{3} 32) \\ & q(312) \\ & \mathbb{B} \cdot(313) \\ & \Gamma(314) \\ & N(322) \\ & \chi(534) \\ & I(412) \\ & \mathfrak{y}(\overline{8} 11) \\ & \Phi(\overline{5} 46)\end{array}$

On crystals of both types individual forms may be lacking, but a mingling of forms characteristic of the two types never occurs.

According to Ungemach's definitions all of the crystals described by Whitlock and by Kraus and Cook fall in type 1. Of those studied by Görgey and Goldschmidt only two (Nos. 5 and 8) are of type 1, all others being of type 2. Of the eight crystals studied by Ungemach himself Nos. 1 and 2 belong to type 1 and the other six belong to type 2. So rigidly does he regard his definitions that he suggests that Görgey and Goldschmidt may be in error when they give the form $P$ (332), characteristic of type 2, as occurring on their crystal No. 8, which otherwise agrees with type 1 .

In minerals which are liable to great variation in habit, such as datolite, the development is commonly susceptible to variation with variation in the conditions attending deposition. Variation of composition, temperature, and pressure of solutions depositing the mineral are ordinarily shown by differences in the habit of the crystals. Where a single locality produces crystals of two or more distinct habits the difference can usually be found to be due to the fact that the crystals of different types belong to different generations. At the Westfield quarries, as previously mentioned, the datolite seems to have been deposited from a single set of solutions and the mineral in all veins and cavities over a large area seems to be practically contemporaneous in time of formation or deposition. Only one generation of datolite is represented, and no other mineral is exactly con- 
temporaneous with the datolite. There was probably more or less variation in the temperature and composition of the solutions from cavity to cavity, but such variation was gradual and the total differences were small. This condition of affairs is represented in the crystals by very gradual variation. Those of any one cavity are identical in habit except for differences due to varying distortion caused by interference of adjacent crystals during growth. Although the crystals on different specimens commonly show distinct differences in habit, the variation is seen to be gradual when a large number of specimens are examined.

While the several types which have been described would be distinct and easily definable were only a few crystals, showing the extremes of development at hand, the examination of such a large number of crystals as has been accessible for the present investigation

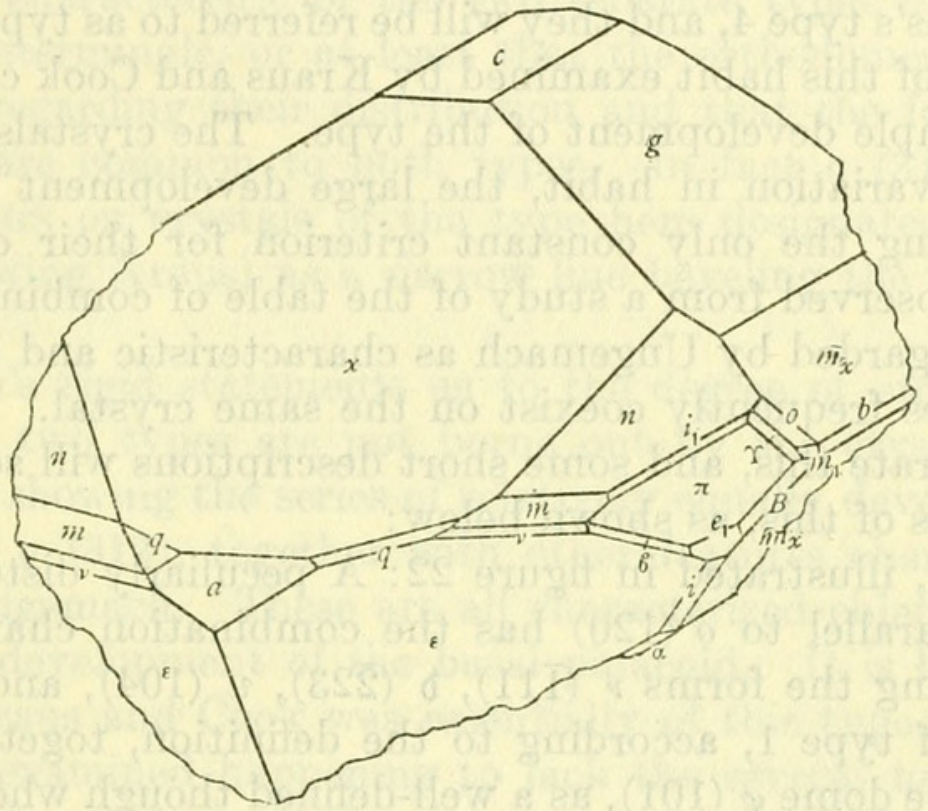

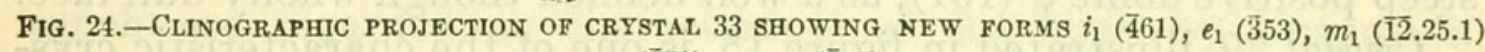
$\Upsilon(\overline{3} 51)$ AND $6(\overline{3} 43)$.

reveals such a gradual transition from type to type through intermediate habits that the definition of types becomes futile. All of the habits described by Kraus and Cook can be illustrated by crystals selected from the series at hand. Their type 1 is by far the most abundant habit represented at the locality. The forms noted by them are all of common occurrence except the three forms which they gave as new, $m_{\mathrm{y}}, n_{\mathrm{y}}$, and $n_{\mathrm{z}}$. Numerous other accéssory forms were seen on crystals of this type, most of them being of infrequent occurrence, as noted under the discussions of forms. Figure 3 is given to show the general appearance of these crystals in orthographic and clinographic projection. Such crystals are well illustrated in the photographs (pls. 104-105). From this typical development the crystals vary in one direction by suppression of the basal pinacoid to acute pyramidal types similar to type 2 of Kraus and Cook, as illustrated in figure 5. These crystals are commonly smaller and less 
rich in forms than the typical or type 1 habit. The dominant forms are the positive orthodome $x$ (102) and the negative hemipyramid $\epsilon(112)$. There is a gradation in the opposite direction toward a type more or less prismatic by elongation on the $a$ axis, as shown in figure 4. Crystals as extreme in development as that here illustrated are relatively uncommon. The basal pinacoid, which on the type 1 crystals is represented by a small, nearly triangular face, is here an elongate rectangle. Crystals of this habit seldom show a very large development of the base. Certain other crystals which show a prominent development of the front pinacoid may be referred to type 3 of Kraus and Cook as illustrated in figure 6 .

Ungemach's definitions are considered to possess an unjustified rigidity. Crystals of his type 2 are abundant in those studied by the writer. They all show a more or less prominent basal pinacoid, as does Kraus's type 4, and they will be referred to as type 4, although the crystals of this habit examined by Kraus and Cook chanced to be the most simple development of the type. The crystals of this type show some variation in habit, the large development of the basal pinacoid being the only constant criterion for their classification. As will be observed from a study of the table of combinations given, the forms regarded by Ungemach as characteristic and diagnostic of his two types frequently coexist on the same crystal. Some of the figures illustrate this, and some short descriptions will serve to point out examples of this, as shown below:

Crystal 65, illustrated in figure 22: A peculiarly distorted crystal elongated parallel to $o(120)$ has the combination characteristic of type 1 , having the forms $\nu$ (111), o (223), $u$ (104), and $v$ (103), all diagnostic of type 1 , according to the definition, together with the steep positive dome $\varphi(101)$, as a well-defined though wholly dull face.

Crystal 39, illustrated in figure 15, is one of the characteristic crystals of what is here adopted as type 4. It shows $q$ (312) and $s$ (302) as small dull faces and $\Sigma(\overline{3} 02)$ as a well-defined face. These three type 2 forms are accompanied by the type 1 form $\nu$ (111), which is present as brilliant faces.

Crystal 43 , showing development typical of type 1 and the diagnostic type 1 form $\nu$ (111), has the type 2 forms $q$ (312) and s (530) as well-developed faces.

Crystal 44, a part of which is shown in figure 20, is also a large crystal typically developed like type 1 and showing the type 1 form $\nu$ (111), together with the type 2 form $q(312)$ and the new form $\mathfrak{u}(\overline{2} 11)$.

Crystal 7, a somewhat broken crystal, has $x$ (102) as the only prominent form in the orthodome zone. This crystal shows one face of $q$ (312) and two small faces of $\eta(\overline{8} 11)$ with one narrow but distinct face of $\nu(111)$. 
Crystal 56 is distinctly tabular parallel to the base and otherwise resembles crystals referred to Ungemach's type 2, shows $\nu$ (111) and o (223) with flat positive orthodomes \& (205), $\mathfrak{S}$ (308), $v$ (103), and $u$ (104), all type 1 forms, with the rare form $w(324)$, characteristic of type 2.

Crystal B8, shown in figure 11 , shows $\nu$ (111), with $\&$ (205), $v$ (103), and $u$ (104), characteristic of type 1 , with a well-developed face of $q(312)$.

Crystal 36 shows $q$ (312) as brilliant faces and also a steep dome $\mathfrak{M}$ (403), both characteristic of type 2 , together with brilliant faces of $\nu$ (111) and of the flat domes $\mathfrak{F}$ (308), $v$ (103), and $u$ (104); characteristic forms of type 1 .

Numerous other examples might be cited to show that the forms regarded as characteristic of the two separate types by Ungemach frequently intermingle, or at least that the orthodomes are subject to no laws regarding their distribution and that the forms $q$ (312) and $\nu$ (111) are common to both types. In fact $q$ (312) very frequently occurs on crystals of the type here designated as types 1 and 2 (following Kraus) as a narrow line beveling the edge $x(102)$ $\wedge \epsilon(\overline{1} 12)$.

Ungemach's rigid statements as to the degree of etching on the faces of the two types are not borne out by the crystals studied. The crystals showing the series of relatively equally developed orthodomes show $q$ (312), together with other features characteristic of type 2 of Ungemach. These are all characterized chiefly by a relatively large development of the basal pinacoid. It is believed that type 4 of Kraus and Cook was essentially of this type, the crystals which they examined happening to lack the several unusual forms which are regarded as characteristic of the type by Ungemach. Many of the crystals of this type are more or less prismatic on the $a$ axis, although others are nearly equidimensional. In the positive orthodome zone, instead of $x$ (102) developed as the only prominent form, there often occurs a series of several narrow faces, which may include not only five or six well-defined forms but also several vicinal planes $1^{\circ}$ or more from the established forms. This series of front domes, which during the study of the crystals was designated as "scintillating," is highly characteristic of crystals of this type, as shown in figures 7 and 15. It is not always present, however. Thus in crystal B11, shown in figure 14, the only forms in this zone are $x$ (102) and $v(103)$. The crystal B10, shown in orthographic projection on the front pinacoid in figure 23 , contains a larger number of the forms listed by Ungemach as characteristic of his type 2 than any other crystal examined by the present writer, namely $\Sigma(\overline{3} 02)$. $z(\overline{2} 01), P(\overline{3} 32), \Phi(\overline{5} 46), \mathfrak{y}(\overline{8} 11)$, and $\Theta(140)$. This crystal was taken from the small specimen shown in plate 106, all of the crystals of 
which are similar in development and agree closely with Ungemach's description of the type. As a matter of fact the form $P(332)$ is a comparatively rare form, while $\nu$ (111) is much more common on this type of crystals. So far as seen the form o (223), which is almost invariably present on the crystals of type 1 (Kraus), does not occur on those of type 4 (Ungemach's type 2). On the latter crystals $\epsilon(\overline{1} 12)$ is often the steepest negative clinopyramid present.

\section{DISTORTION.}

Distortion, or unequal development of corresponding faces on opposite portions of the crystal, is the rule rather than the exception. Symmetrically developed crystals are rare, and various freakish developments are so common and so variable that they can not be described in detail. As typical examples of distortion, crystal 65 (fig. 22) and crystal B5 (fig. 13) may be cited. Crystal 65 is prismatic by elongation parallel to $o(120)$ and is so unsymmetrical that were it not for the characteristic etchings of the various faces its orientation would have been almost impossible. Crystal B5 is unequally developed, so as to give the basal pinacoid the outline of a right triangle and to bring the new positive orthodome $\&$ (205), which is present as a relatively large dull face, adjacent to the pyramid $\kappa(115)$, this unusual angle being beveled by the new form $j_{1}$ $(\overline{5}-6-30)$, which is dependent for its occurrence on this unusual development. The unequal development of crystals of type 1 is often expressed by the unsymmetrical outline of the basal pinacoid, which is right triangular in outline. Ideal development has been prevented in most crystals by mutual interference during growth, and more than one quadrant of a crystal is rarely developed, so that what form would have been assumed by the missing faces can not be surmised.

\section{IRREGULARITIES OF THE CRYSTAL FACES.}

Dana writes with regard to datolite: "Faces often wavy and rarely giving good measurements; $x$ (102) commonly dull." The difficulties encountered in properly orienting crystals of datolite render certain peculiarities of several of the more prominent faces occurring on this mineral very important. Consequently the several forms, faces of which exhibit peculiarities of surface of sufficiently constant oceurrence to be of value as orienting criteria, deserve special description. No two crystals are alike in the irregularities of surface shown by the planes, the surfaces, even when highly lustrous, showing an infinite variety of patterns and tracings, the detailed description of which might occupy many pages. Certain features are, however, comparatively constant and serve as a most convenient guide in orienting the crystals. The most useful of these are as follows: 
$c$ (001), the basal pinacoid, is seldom free from irregularities. These most frequently take the form of narrow depressed "ruled" lines in three directions, which are parallel to the unit prism $m$ (110) and the orthopinacoid $a$ (100). These sometimes are not etched, but are merely shallow depressions. They form, however, lines susceptible to attack by etching agents and are often greatly deepened by natural solution. The effect is to divide the face into triangular areas or to produce deep triangular pits or depressions. This plane has been one of the most easily attacked by corroding solutions. Sometimes this pinacoid is wholly dull. The characteristic three directional lines at times look like traces of cleavage, but no cleavage parallel to these directions could be proven to exist in the crystals. Such triangular rulings were artificially produced by the action of dilute hydrochloric acid on a crystal which did not originally show them.

$x$ (102), which in the majority of the crystals is one of the most prominent faces, is most frequently dull, as in datolite from other localities. At times this dullness appears as a uniform etching over the whole face, giving the appearance of finely ground glass. More frequently the etching has taken the form of broad irregular lines, which divide the face into lozenge-shaped patches, separated by broad depressed channels. In other instances there appears a large irregular etched depression in the center of the face, from which crooked lines ramify in all directions. When the faces of this form are unetched they are horizontally striated by oscillatory lines, which increase in number and distinction toward the top of the face.

$\epsilon(\overline{1} 12)$ and also $\lambda(\overline{1} 13)$ and to a less extent $\mu$ (114) are characteristically marked by an oscillatory horizontal striation. This is a most constant and diagnostic peculiarity of the important form $\epsilon$ (112), which is always lustrous and free from corrosion.

$o$ (120) and the pyramids of the same vertical zone as $\mathrm{U}$ (123), $\mathrm{Q}$ (122), $\beta$ (121), and $\mathrm{M}$ (122) are almost invariably dull by the presence of "ground glass" etched surfaces, which, while variable in degree, are almost never wholly absent. This etching renders these faces readily identifiable, thus greatly facilitating proper orientation.

$\nu$ (111) and o (223) are often deeply etched to a uniform dull surface, which often reflects little if any light. Some of the etched faces have a peculiarly iridescent luster. The etching of these forms is very variable in degree and is frequently not present.

$m$ (110) and $n$ (111) are often ruled by parallel grooves due to oscillation between the two forms. These grooves are sharp reentrant angles and are not accompanied by any rounding, so that both faces give perfectly sharp signals. While not invariably present, these grooves serve immediately to identify these faces when they do occur- 
In single crystals or those of a single specimen or cavity almost any form may be etched to complete dullness. The forms of the clinodome zone are almost invariably brilliant and free from etching of any sort, yet on one crystal measured the form $g(012)$, present as a large face, was entirely dull. As before stated, various other irregularities occur, but not with sufficient regularity to be of value in form identification. Many of the other forms are characteristically etched, but these occur as faces too small to be of value in orienting the crystals.

FORMS.

Whitfield described the following 27 forms on datolite from Westfield:

$a(100), b$ (010), $c$ (001), $m$ (110), $r(230), o(120), x$ (102), $v$ (103), $m_{\mathrm{x}}$ (011), $g$ (012), $\Omega$ (018), $t$ (013), $n$ (111), $\nu$ (111), $\epsilon$ (112), $\lambda$ (113), $\mu$ (114), $\kappa$ (115), $Q$ (122), $\beta$ (121), $M$ (122), $i$ (123), $\alpha$ (124), $\epsilon^{\prime}$ (148), $\lambda^{\prime}$ (149), $\mu^{\prime}$ (1.4.10).

Of these $M$ (122), $\epsilon^{\prime}$ (148), $\lambda^{\prime}$ (149), and $\mu^{\prime}$ (1.4.10) were new to the species.

Kraus and Cook confirmed all forms observed by Whitlock except $\lambda^{\prime}(149)$ and $\Omega$ (018) and added as forms new to the locality $l$ (130), D (223), $\pi$ (231), $u$ (104), $\xi(102)$ and as forms new for the species $m_{y}$ (067), $m_{\mathrm{z}}(0.1 .10), n_{\mathrm{y}}$ (1.1.10).

Gorgey and Goldschmidt observed 45 forms, of which 11 were new to the locality, namely:

$\sigma(014), \Sigma(302), \Pi$ (101), $q$ (312), n (132), $T$ (214), $U$ (123), B (121), $N$ (322), $\Gamma$ (314), $\chi(534)$, and 8 new to the species, namely:

$\mathfrak{S}$ (308), P (332), b (118), H (131), $\mathfrak{N}$ (126), $\mathfrak{B} \cdot(313), \Re(454)$, y $(\overline{9} 11)$.

Ungemach found 60 forms, of which the following 6 were new for the locality:

$\psi(201), \eta(410), \Delta(210), \omega(116), Y_{1}$ (134), $d$ (135), and 9 which were new to the species, namely:

$y$ (601), $j$ (502), $k:(3.0 .10)$, s (530), $\theta$ (140), $\Xi$ (136), $I \cdot(412)$, $\Phi(\overline{5} 46), \mathfrak{y}(\overline{8} 11)$, ? (11.0.2).

Thus at the beginning of the present investigation there had been reported on datolite from this locality 68 forms, of which 24 were new to the species. The present writer has recognized on the crystals studied during the present investigation 104 forms, of which 10 are new to the locality, as follows:

$p$ (106), $I$ (203), $s$ (302), $z$ (201), $\Lambda$ (112), $M_{1}$ (231), 爪 (454), $\mathfrak{r}$ (132), $E$ (138), $\mu_{1}(\overline{2} 27)$, and 46 forms which are new for the species, as follows:

(5 (380), I (043), \& (205), vic. (16.0.39), $\mathfrak{M}$ (403), (12.0.25), $\mathfrak{D}(134), \mathfrak{F}(192), \mathfrak{\Omega}(1.10 .2), \Re(1.12 .2), \subseteq(331), \mathfrak{I}(343), \mathfrak{U}(344)$, 


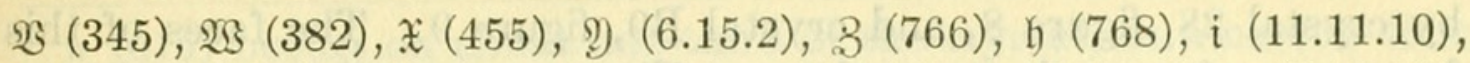

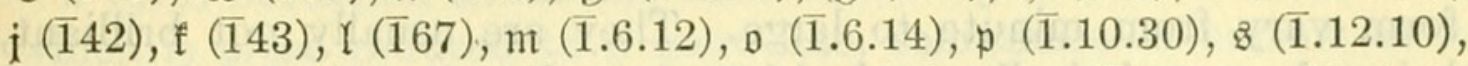
t (1.20.15), u (211), x (229), z (263), $\theta$ (295), 8 (296), $\dot{\rho}$ (2.10.5),

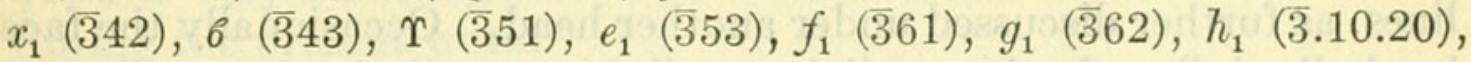
$i_{1}$ (461), $j_{1}(\overline{5} .6 .30), k_{1}$ (794), $l_{1}(\overline{9} .16 .2), m_{1}(\overline{12} .25 .1)$.

Of the latter, however, a considerable proportion were observed only once as very small faces giving faint signals, and they therefore require additional confirmation as emphasized below. Of the forms previously recorded from the locality the following 19 were not found:

$\Omega$ (018), $m_{\mathrm{z}}$ (0.1.10), $n_{\mathrm{y}}$ (1.1.10), $\mathfrak{n}(132), T(214), \mathfrak{b}(118), J_{1}$ (311), B. (313), $\Gamma$ (314), $\chi$ (534), y (911), $Y_{1}(134), \Delta(210), y$ (601), $j$ (502),

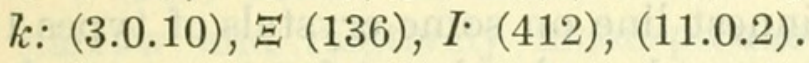

The combinations on the majority of the crystals are more or less similar. In general the number of forms present varies with the size of the crystal, many of the rarer forms being confined to the larger crystals, while small crystals are usually simple in combination. The rarer forms are erratically distributed. It might be possible to measure 100 crystals and find only relatively common forms, while one additional crystal might show 10 or more new or rare forms. Rare forms seldom occur singly, more frequently occurring as small nests of several unusual faces. Although the present examination covered a relatively large number of crystals, it is entirely probable that the examination of additional crystals from this locality will reveal additional rare and new forms. The different forms observed are described in detail below.

\section{COMMON FORMS.}

a (100) is practically never absent except where it has been destroyed by breaking of the crystal or by confinement during growth. The faces of this form vary from small triangles, sometimes minute, on crystals of types 1 and 2 , shown in figures 3 , 4, and 5 , to large polygons on crystals of types 3 and 4 . The largest development of this form is shown by type 3 , illustrated in figure 6 , where the front pinacoid is one of the most prominent faces. The faces of this form are invariably brilliant and never show any characteristic etching or irregularity.

$b$ (010), the clinopinacoid, is usually though not invariably present. It is commonly a linear face, varying from a fairly broad to a very narrow line. It is almost invariably bright and yields good signals even when very narrow.

$c$ (001), the basal pinacoid, is usually present, although it occasionally fails, as in crystals of type 2 shown in figure 5 , and also occasionally on crystals referable to other types, as shown, for example, 
by crystal 28 , figure 8 , and crystal B9, figure 9 . The faces of this form vary from minute to large. They are usually not brilliant, being characteristically marked by triangular pits or ruled depressed lines, as further discussed under another head. Occasionally the face is wholly dull, reflecting no light at all, but usually it gives a distinct although somewhat furred signal. On crystals of type 1 the base is usually more or less triangular in outline, as shown in figures 3 and 16. It may also be represented by a narrow line, as shown in figure 4 . On crystals of type 4 (type 2 of Ungemach) the base is the most conspicuous form, many of the crystals of this type being distinctly tabular parallel to this face.

$m$ (110), the unit prism is not absent from any crystal examined, although it varies from the thinnest line on some crystals of types 1 and 2, figures 3 and 5, to a large and predominant face on crystals of types 3 and 4 , as shown in figure 6 . It is usually a plane and brilliant face, yielding excellent signals. The only characteristic irregularity present is a grooving by reentrant angles, produced by oscillatory alternation between $m(110)$ and $n$ (111), as described above.

$o$ (120) occurs on somewhat more than half of the crystals examined. It varies from a very small to a fairly large face, being exceedingly variable in outline. On crystals of types 1 and 2 it is oftenest shown as a relatively narrow faces truncating the angle $\nu$ (111) $\wedge m_{\mathbf{x}}(011)$, as shown in figures 5 and 16 . Other characteristic outlines are shown also in figures 4,7 , and 23 . The most prominent type of development of this form is shown by crystal 51, illustrated in figure 17. The luster of the face is almost never perfect, the etching varying from a faint satiny sheen to complete lack of luster. Usually the faces of this prism, like others in the same vertical zone, yield clear and sharp though faint signals, which are sometimes blood red in color and appear as though viewed through a haze.

$r$ (230) occurs on about one-fourth of the crystals examined, usually as a small face, as well illustrated by crystal 51, shown in figure 17, and crystal B10, shown in figure 23. The face lies between $m$ (110) and $o$ (120) and usually yields a fair signal. It is frequently etched lightly but is not so characteristically so as is $o(120)$.

$m_{x}(011)$ is invariably present, usually as one of the most prominent and brilliant faces. While sometimes slightly wavy, it is always brilliant and yields excellent signals.

$g(012)$ is practically always present as a prominent and brilliant face, yielding good measurements.

$t$ (013) is present on about half of the crystals studied, occurring as a narrow face, giving good signals. It is much less prominent than the two steeper clinodomes $m_{\mathbf{x}}(011)$ and $g(012)$. 
$\sigma(014)$ occurs on about one-third of the crystals as a narrow face, which is often reduced to a mere line, sometimes so narrow as to yield a very faint signal. This is the flattest clinodome observed during the present work.

$x$ (102) is the only orthodome which is invariably present, and on many crystals it is the most prominent form. It is nearly always etched to a greater or less extent and in various manner, as described elsewhere. The form commonly yields a good signal. On crystals of types 1 and 2 it may be very large, as shown in figures 3, 5, and 16 , while on crystals of type 4 it may not be more conspicuous than the other forms in this zone, as shown in figures 7,8 , and 15 .

$v$ (103) occurs on about one in each three crystals, usually as a narrow and relatively inconspicuous face. It varies from bright through various degrees of etching to wholly dull, reflecting no light at all. Quite frequently the form can be measured only by the expedient of moistening the face with alcohol, and some of the less completely etched forms give red signals.

$u$ (104) occurs much as does $v$ (103), the two forms often occurring together and being similar in size, outline, and degree of etching.

$n$ (111), the only common positive pyramid in this vertical zone, is always present. It varies from a small triangular face, as in the crystals of type 2 , figure 5 , to a prominent form. The faces of this form are always brilliant and yield a sharp signal. The only characteristic irregularity of the surface of the faces is the presence of the reentrant angles formed by oscillation between $n$ (111) and $m$ (110).

$\beta$ (121) occurs on about one-fourth of the crystals measured as a small face, which is often more or less etched. Characteristic occurrences of this form are shown by crystal 10 (fig. 16), 36 (fig. 7), 51 (fig. 17), B9 (fig. 9), B10 (fig. 23), and B11 (fig. 14).

$Q$ (122) occurs frequently with $\beta$ (121) and, like it, is usually etched. It falls between $n$ (111) and $m_{\mathrm{x}}$ (011). It varies from a relatively prominent face, as shown in figure 17 , crystal 51 , to a narrow line, as shown by figure 16 of crystal 10 .

$U$ (123) is about as frequent in occurrence as $\beta$ (121) and $Q(122)$, and like them is often etched lightly. It falls between $n(111)$ and $g(012)$ and can easily be identified by its position. Typical outlines and positions of this form are shown by figures 4, 6, and 23 .

$\nu$ (111) is a common form, being present on over half of the crystals examined. This form is considered characteristic of his type 1 crystals by Ungemach, but was frequently observed during the present examination in combination with $q(312)$ and other forms characteristic of Ungemach's type 2. This is shown by the figured crystal B8 shown in figure 11, etc. This form is usually represented by a narrow 
face, often a mere line, but may be more prominent, as shown, for example, by crystals 10 (fig. 16) and B7 (fig. 10). On type 4 crystals it is usually narrow and brilliant, yielding excellent measurements, while on other types of crystals the form is usually larger and more or less dull and etched.

b (223) is a characteristic form on Westfield datolite occurring on one-third of the crystals measured. Unlike $\nu$ (111) it is practically confined to crystals classed as type 1 by Ungemach, and occurs almost invariably on crystals of type 1 , as defined here, as a moderately narrow to relatively broad face between $\nu$ (111) and $\epsilon(112)$. It is often more or less etched. Typical occurrences are shown in figures 10,11 , and 17 .

$\epsilon(112)$ is a universally present form, and ordinarily it is the most prominent pyramid. It determines the form of crystals of type 2, shown in figure 5 , and of the similar type shown in figure 8 . The faces are horizontally striated and are often more or less irregular yielding multiple signals.

$\lambda$ (113) is invariably present where not destroyed by interference. It is commonly a narrow face which is bright and gives a good signal.

$\mu$ (114), like $\lambda$ (113), is commonly present as narrow bright faces, giving good signals.

$\kappa(115)$ is of relatively infrequent occurrence, being found on about 1 in every 10 crystals. It is narrower than $\mu(\overline{1} 14)$, but yields good signals.

$i(\overline{123})$ is a common form, occurring on half of the crystals studied. It forms a narrow but brilliant face, beveling the angle between $\epsilon(\overline{1} 12)$ and $m_{\mathbf{x}}(0 \overline{1} \overline{1})$. Its characteristic form and position are well shown by figures 4 and 6 .

$\alpha$ (124) occurs on about 1 in every 4 crystals studied, being similar to $i$ (123) in form and occurrence. It forms a narrow but bright face beveling the edge between $g(01 \overline{2})$ and $\epsilon(\overline{1} 12)$, as shown by figures 4 and 10 (crystal B7). Occasionally it is present as a broader face, as shown in figure 16 (crystal 10).

$\pi(\overline{2} 31)$, elsewhere a rare form for datolite, is a characteristic form at Westfield, occurring on every second crystal. It occurs commonly as a narrow face, beveling the angle between $o(120)$ and $\nu(111)$, as shown by figures 17 (crystal 51) and 16 (crystal 10). Where $\nu$ (111) is absent this form occurs as a larger triangular face, as shown, for example, in figures 23 (crystal B10) and 14 (crystal B11). The most conspicuous development of this form is shown in figure 24 (crystal 33 ), where it forms the center of a small group of rare and new forms. Commonly the faces of $\pi(\overline{2} 31)$ are more or less delicately etched, so as to give them a silky sheen, although the form usually yields clear and brilliant signals. 
LESS COMMON AND RARE FORMS.

$l$ (130) may be considered one of the rarer forms, as it occurs on only about one-tenth of the crystals studied. It is usually present as a very small and more or less dull face. Its typical occurrences are illustrated by figures 12 (crystal B8) and 9 (crystal B9).

$\theta$ (140) a prism, first described by Ungemach as a new form occurring on datolite from this locality, was seen once as a narrow and dull face on crystal B10 between $M(122)$ and $m_{\mathrm{x}}$ (011), as shown in figure 23. The signal from the face was very faint, due to etching, although the face was moderately conspicuous. The angle measured does not compare very well with the calculated values as shown below:

$$
\begin{aligned}
\text { (140) Measured } \varphi & =20^{\circ} 55^{\prime} & & \rho=90^{\circ} 00^{\prime} \\
\text { Calculated } \varphi & =21^{\circ} 30^{\prime} & \rho & =90^{\circ} 00^{\prime} \\
\Delta & =0^{\circ} 35^{\prime} & \Delta & =0^{\circ} 00^{\prime}
\end{aligned}
$$

s (530), another prism described as new from Westfield by Ungemach, was observed on one crystal, No. 43 , as bright faces, as shown in figure 21. The angles measured compare as follows:

$$
\begin{aligned}
\text { Measured } \varphi & =69^{\circ} 31^{\prime} & & \rho=90^{\circ} 00^{\prime} \\
\text { Calculated } \varphi & =69^{\circ} 10^{\prime} & & \rho=90^{\circ} 00^{\prime} \\
\Delta & =0^{\circ} 21^{\prime} & \Delta & =0^{\circ} 00^{\prime}
\end{aligned}
$$

The form is thus confirmed.

$m_{\mathrm{y}}(067)$ was doubtfully identified once, on crystal B5, as a small face giving a poor signal. Some doubt attaches to the identification, however, as the face may have been $m_{\mathbf{x}}(011)$ of a crystal not quite in parallel position. The corresponding face on the opposite side of the crystal was $m_{\mathrm{x}}$ (011). The angles measured are as follows:

$$
\begin{aligned}
\text { (067) Measured } \varphi & =0^{\circ} 41^{\prime} & & =48^{\circ} 20^{\prime} \\
\text { Calculated } \varphi & =0^{\circ} 08^{\prime} & \rho & =47^{\circ} 19^{\prime} \\
\Delta & =0^{\circ} 33^{\prime} & \Delta & =1^{\circ} 01^{\prime}
\end{aligned}
$$

$\phi(101)$ was recorded as occurring on Westfield datolite by Görgey and Goldschmidt. Ungemach takes exception to their identification as follows: " $\psi$ (201), which is here given as new was apparently observed by Görgey and Goldschmidt, but owing to the curvature of its faces it was only tentatively identified by them and then as $\phi$ (101). The authors say that the signals from the curved face yield a train of light in the center of which the position of (101) lies. In my crystals there is no trace of $\phi(101)$, while the train of light begins quite sharply at the position of $\psi(201)$ and extends through the short arc to the position of $a$ (100)." In the present examination the phenomenon described by Görgey and Goldschmidt - that is, a 
train of signals centering at the position of $\phi(101)$-was observed on crystal 58 (fig. 6). This form was also identified with moderate certainty on crystal 65 (fig. 22) as a well-defined face. This was wholly without reflection but was approximately measured by moistening with alcohol yielding the following angles:

$\begin{aligned} \text { (101) Measured } \varphi & =90^{\circ} 00^{\prime} & \rho & =59^{\circ} 34^{\prime} \\ \text { Calculated } \varphi & =90^{\circ} 00^{\prime} & \rho & =53^{\circ} 24^{\prime} \\ \Delta & =0^{\circ} 00^{\prime} & \Delta & =3^{\circ} 50^{\prime}\end{aligned}$

In several other instances narrow and wholly dull faces were seen which were thought to be this form, but owing to their failure to reflect any light they could not be measured.

$p$ (106) was tentatively identified as a narrow line yielding a very dim and not accurately measureable signal on crystal 10, as shown in figure 16. The angles obtained are as follows:

(106)

$$
\begin{aligned}
\text { Measured } \varphi & =90^{\circ} 00^{\prime} & \rho & =21^{\circ} 00^{\prime} \\
\text { Calculated } \varphi & =90^{\circ} 00^{\prime} & \rho & =18^{\circ} 31^{\prime} \\
\Delta & =0^{\circ} 00^{\prime} & \Delta & =2^{\circ} 29^{\prime}
\end{aligned}
$$

$I$ (203) was observed twice, once on crystal 7 as a small face, somewhat etched and giving a faint signal, which yielded angles compared as follows:

(203)

$$
\begin{aligned}
\text { Calculated } \varphi & =90^{\circ} 00^{\prime} & \rho & =53^{\circ} 07^{\prime} \\
\text { Measured } \varphi & =90^{\circ} 55^{\prime} & \rho & =54^{\circ} 51^{\prime} \\
\Delta & =0^{\circ} 55^{\prime} & \Delta & =1^{\circ} 44^{\prime}
\end{aligned}
$$

This form also occurred as a well-defined though narrow face on crystal B5, shown in figure 13 , which gave the angles:

$$
\begin{aligned}
\text { Measured } \varphi & =89^{\circ} 41^{\prime} & \rho & =53^{\circ} 25^{\prime} \\
\Delta & =0^{\circ} 19^{\prime} & \Delta & =0^{\circ} 08^{\prime}
\end{aligned}
$$

$s$ (302) was found as very narrow faces, yielding poor signals, on crystals B5 (fig. 13) and 39 (fig. 15). The angles are as follows:

(302) Calculated

Crystal B5, measured $\varphi=89^{\circ} 48^{\prime}$

$$
\begin{aligned}
& \varphi=90^{\circ} 00^{\prime} \quad \rho=71^{\circ} 18^{\prime} \\
& \Delta=0^{\circ} 12^{\prime} \quad \Delta=2^{\circ} 16^{\prime} \\
& \text { Crystal 39, measured } \varphi=90^{\circ} 04^{\prime} \quad \rho=70^{\circ} 00^{\prime} \\
& \Delta=0^{\circ} 04^{\prime} \quad \Delta=1^{\circ} 18^{\prime}
\end{aligned}
$$

5..(308), described as new on Westfield datolite by Görgey and Goldschmidt, was found on six crystals. It is usually present as a small or narrow face, which is sometimes bright, but is more frequently etched or "matte," yielding a dim or a red signal. It occurs 
as a small triangular face, which is somewhat dull on crystal B9, which is illustrated in figure 9. The angles for this form are as follows:

(308)

$\begin{array}{lll}\text { Calculated } \varphi=90^{\circ} 00^{\prime} & \rho=36^{\circ} 54^{\prime} \\ \text { Measured, maximum } \varphi=91^{\circ} 28^{\prime} & \rho=37^{\circ} 48^{\prime} \\ \text { Measured, minimum } \varphi=89^{\circ} 28^{\prime} & \rho=36^{\circ} 49^{\prime} \\ \text { Measured, average } \varphi=90^{\circ} 26^{\prime} & \rho=37^{\circ} 14^{\prime} \\ \Delta & =0^{\circ} 26^{\prime} & \Delta=0^{\circ} 20^{\prime}\end{array}$

$\xi$ (102) was seen several times on crystals of types 1 and 4 . On type 1 crystals it occurs usually as a very narrow line, beveling the edge between $\epsilon(\overline{1} 1 \overline{2})$ and $\epsilon^{\prime}(\overline{112})$. On crystals of type 4 it may be present as a relatively broad face, yielding measurements agreeing closely with the calculated angles for the form. It is shown in typical development on crystals 36 (fig. 7) and 39 (fig. 15).

$\Sigma(\overline{3} 02)$ occurs occasionally as a relatively small face, which, though slightly etched and having a satiny sheen, yields sharp signals. It is shown in typical development on crystal 39 (fig. 15), crystal 27 (fig. 7), and crystal B10 (fig. 23).

II (101) occurs occasionally with $\Sigma(\overline{3} 02)$ as a narrow face, which is sometimes dull and etched.

$\Lambda$ (112) is a rare form on datolite from Westfield. Only one crystal (B4) showed measurable faces of this form, which gave the angles

$$
\begin{aligned}
\text { Calculated } \varphi & =57^{\circ} 40^{\prime} & \rho & =49^{\circ} 48^{\prime} \\
\text { Measured } \varphi & =57^{\circ} 40^{\prime} & \rho & =49^{\circ} 50^{\prime} \\
\Delta & =0^{\circ} 00^{\prime} & \Delta & =0^{\circ} 02^{\prime}
\end{aligned}
$$

The form was seen on two or three other crystals as very small and dull faces.

$M_{1}$ (231), a form previously described by Ungemach on datolite from Sainte Marie, was doubtfully identified on crystal B8 as a narrow line face beveling the angle $o(120) \wedge n$ (111), as shown in figure 12. The signal from the narrow face was so faint that it could be measured only approximately, owing to lack of visibility of the cross hairs. The angles are:

(231)

$$
\begin{aligned}
\text { Calculated } \varphi & =46^{\circ} 26^{\prime} & \rho & =79^{\circ} 43^{\prime} \\
\text { Measured } \varphi & =44^{\circ} 48^{\prime} & \rho & =81^{\circ} 34^{\prime} \\
\Delta & =1^{\circ} 38^{\prime} & \Delta & =1^{\circ} 51^{\prime}
\end{aligned}
$$

$q$ (312) should perhaps be included with the common forms, as it occurred on approximately one-third of all the crystals examined. On type 1 crystals it frequently forms a narrow line, beveling the edge $x(102) \wedge(111)$. On type 4 crystals it is almost invariably present as small triangular faces at the upper corners of the front pinacoid. Although normally clear and brilliant, yielding excellent signals, the faces of this form are occasionally somewhat etched. 
$\omega(324)$ was observed on crystal 56 and on several similar crystals from the same specimen as a very narrow line beveling the angle between $m$ (110) and $x$ (102). The angles are:

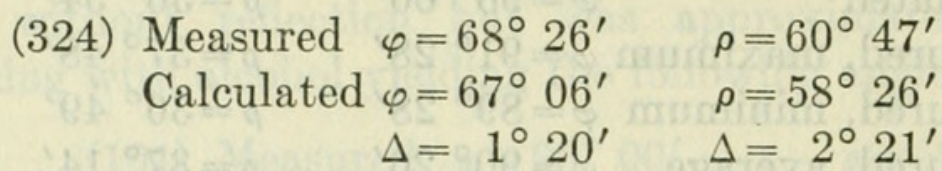

$\Omega(454)$ occurred on crystal B9 as a very narrow face beveling the angle between $n$ (111) and $\beta$ (121), as shown in figure 9. The signal was so faint as to not be accurately measurable in the presence of adjacent brilliant forms. The angles are:

$$
\begin{aligned}
\text { Measured } \varphi & =53^{\circ} 29^{\prime} & & \rho=67^{\circ} 28^{\prime} \\
\text { Calculated } \varphi & =51^{\circ} 36^{\prime} & \rho & =68^{\circ} 34^{\prime} \\
\Delta & =1^{\circ} 53^{\prime} & \Delta & =1^{\circ} 06^{\prime}
\end{aligned}
$$

$\omega$ (116) was found on but two of the crystals studied. On crystal B5 it forms a very narrow line, giving a poor signal, as shown in figure 13 , while on crystal 51 it is present as a somewhat broader face, as shown in figure 17 . The angles are:

$$
\begin{array}{rlrl}
\text { (116) Measured Xl. } 51 \varphi=57^{\circ} 35^{\prime} & \rho=20^{\circ} 25^{\prime} \\
\text { Average B5 } \varphi=57^{\circ} 56^{\prime} & \rho=21^{\circ} 40^{\prime} \\
\text { Calculated } & \varphi=57^{\circ} 45^{\prime} & \rho=21^{\circ} 03^{\prime} \\
\varphi & \varphi=57^{\circ} 24^{\prime} & \rho=21^{\circ} 23^{\prime} \\
\Delta & =0^{\circ} 21^{\prime} & \Delta & =0^{\circ} 20^{\prime}
\end{array}
$$

$B$ (121) was found as a distinct line, giving a poor signal on crystal 33 , as shown in figure 24. On crystal 41 , shown in figure 18 , this form occurred as a bright face, giving a very good signal. The angles are:

(121)

$$
\begin{array}{lrl}
\text { Measured Xl. } 33 \varphi=39^{\circ} 43^{\prime} & \rho=73^{\circ} 39^{\prime} \\
41 \varphi=38^{\circ} 07^{\prime} & \rho=72^{\circ} 43^{\prime} \\
\text { Average } & \varphi=38^{\circ} 55^{\prime} & \rho=73^{\circ} 11^{\prime} \\
\text { Calculated } & \varphi=38^{\circ} 12^{\prime} & \rho=72^{\circ} 46^{\prime} \\
& \Delta=0^{\circ} 43^{\prime} & \Delta=0^{\circ} 25^{\prime}
\end{array}
$$

$M$ (122), which was first reported by Whitlock on Westfield datolite, occurs rather frequently, especially on crystals of type 1, usually as a small face, which is frequently lightly etched. Characteristic outlines are shown in figures $4,7,18$, and 23 . The faces frequently give perfect signals. The angles are:

$$
\begin{array}{lll}
\text { Measured, minimum } & \varphi=38^{\circ} 13^{\prime} & \rho=57^{\circ} 50^{\prime} \\
\text { Measured, average } & \varphi=37^{\circ} 57^{\prime} & \rho=58^{\circ} 09^{\prime} \\
\text { Calculated } & \varphi=38^{\circ} 10^{\prime} & \rho=58^{\circ} 09^{\prime} \\
& \Delta=0^{\circ} 13^{\prime} & \Delta=0^{\circ} 00^{\prime}
\end{array}
$$


$\mathfrak{N}(\overline{1} 26)$. A form near(126) was found on crystal B5 as a very narrow face beveling the angle between $g(012)$ and $\lambda(\overline{1} 13)$. The signal was distinct although too faint to illumine the crosshairs. The angles are as follows:

(126)

$$
\begin{aligned}
\text { Measured } \varphi & =36^{\circ} 27^{\prime} & & \rho=26^{\circ} 58^{\prime} \\
\text { Calculated } \varphi & =38^{\circ} 02^{\prime} & \rho & =28^{\circ} 10^{\prime} \\
\Delta & =1^{\circ} 35^{\prime} & \Delta & =1^{\circ} 12^{\prime}
\end{aligned}
$$

$r$ (132) occurred as a very narrow line face, with (142) on crystal 10 between $M(\overline{1} 22)$ and $b(010)$, as shown in figure 19 . The signal was very faint and could not be accurately centered. The angles are:

(132)

$$
\begin{aligned}
\text { Measured } \varphi & =25^{\circ} 49^{\prime} & & \rho=66^{\circ} 31^{\prime} \\
\text { Calculated } \varphi & =27^{\circ} 40^{\prime} & \rho & =67^{\circ} 59^{\prime} \\
\Delta & =1^{\circ} 51^{\prime} & \Delta & =1^{\circ} 28^{\prime}
\end{aligned}
$$

$d$ (135), which was described as new from this locality by Ungemach, occurred on six of the crystals examined. It forms a small face between $\alpha(\overline{1} 24)$ and $m_{\mathbf{x}}(011)$, as shown in figures $9,10,16$, etc. The faces are usually slightly etched, but give good signals. Angles:

$\begin{array}{lll}\text { (135) Measured, maximum } \varphi=27^{\circ} 44^{\prime} & \rho=40^{\circ} 53^{\prime} \\ \text { Measured, minimum } \varphi=26^{\circ} 49^{\prime} & \rho=40^{\circ} 08^{\prime} \\ \text { Measured, average } \varphi=27^{\circ} 16^{\prime} & \rho=40^{\circ} 30^{\prime} \\ \text { Calculated } & \varphi=27^{\circ} 34^{\prime} & \rho=40^{\circ} 35^{\prime} \\ \Delta=0^{\circ} 18^{\prime} & \Delta=0^{\circ} 05^{\prime}\end{array}$

$E$ (138) was doubtfully identified as a very narrow and partly etched face between $g(012)$ and $\lambda(113)$ on crystal B5, as shown in figure 13. The signal was too faint for accurate measurement. The angles are:

$$
\begin{aligned}
\text { Measured } \varphi & =29^{\circ} 44^{\prime} & & \rho=30^{\circ} 32^{\prime} \\
\text { Calculated } \varphi & =27^{\circ} 31^{\prime} & \rho & =31^{\circ} 27^{\prime} \\
\Delta & =2^{\circ} 13^{\prime} & \Delta & =0^{\circ} 55^{\prime}
\end{aligned}
$$

$\epsilon^{\prime}$ (148) was described as new by Whitlock, together with $\lambda^{\prime}(\overline{1} 49)$ and $\mu^{\prime}$ (1.4.10). All three of these forms occur occasionally as very narrow faces, which are either too narrow to yield distinct signals or are on such very large crystals that their measurement is almost impossible.

$\mu_{1}(\overline{2} 27)$ was observed once as a very narrow line on crystal B2. Angles:

(227)

$$
\begin{aligned}
\text { Measured } \varphi=57^{\circ} 56^{\prime} & \rho=33^{\circ} 33^{\prime} \\
\text { Calculated } \varphi=57^{\circ} 30^{\prime} & \rho=33^{\circ} 56^{\prime} \\
\Delta=0^{\circ} 26^{\prime} & \Delta=0^{\circ} 23^{\prime}
\end{aligned}
$$


$P(\overline{3} 32)$ was seen several times as a brilliant though narrow face. Its best development was on crystal B10, which is illustrated in figure 23. The angles are:

(332)

$$
\begin{aligned}
\text { Measured } \varphi & =57^{\circ} 27^{\prime} & & \rho=73^{\circ} 22^{\prime} \\
\text { Calculated } \varphi & =57^{\circ} 35^{\prime} & \rho & =74^{\circ} 14^{\prime} \\
\Delta & =0^{\circ} 08^{\prime} & \Delta & =0^{\circ} 52^{\prime}
\end{aligned}
$$

This form was described as new from Westfield by Görgey and Goldschmidt.

$\Phi(\overline{5} 46)$, described as new on Westfield datolite by Ungemach, was observed as two rounded faces on crystal B10, shown in figure 23 . It was also seen as two small and dull faces on crystal 7 . The signals from the faces were very poor. Angles:

(546)

$$
\begin{aligned}
& \text { Measured, minimum } \varphi=60^{\circ} 57^{\prime} \quad \rho=59^{\circ} 30^{\prime} \\
& \text { Measured, average } \quad \varphi=61^{\circ} 07^{\prime} \quad \rho=59^{\circ} 49^{\prime} \\
& \text { Calculated } \quad \varphi=63^{\circ} 04^{\prime} \quad \rho=61^{\circ} 46^{\prime} \\
& \Delta=1^{\circ} 57^{\prime} \quad \Delta=1^{\circ} 57^{\prime}
\end{aligned}
$$

$y$ ( 811$)$. The form $y(\overline{9} 11)$ was described as new on datolite from Westfield by Görgey and Goldschmidt. Ungemach described $y(\overline{8} 11)$ as occurring on the crystals examined by him and suggested that the form ( $\overline{9} 11)$ of Goldschmidt and Görgey was the same. The form was seen on crystal B10, illustrated in figure 23, and also as small dull faces on crystal 7 . The angles are:

$$
\begin{array}{lll}
\text { Measured } \varphi=85^{\circ} 00^{\prime} & \rho=86^{\circ} 05^{\prime} \\
(\overline{8} 11) & \text { Calculated } \varphi=85^{\circ} 28^{\prime} & \rho=86^{\circ} 26^{\prime} \\
(\overline{9} 11) & \text { Calculated } \varphi=85^{\circ} 58^{\prime} & \rho=86^{\circ} 49^{\prime}
\end{array}
$$

The measured angles would seem to indicate the form ( $\overline{8} 11)$, although both forms probably occur.

\section{RELATIVE IMPORTANCE OF FORMS.}

The forms found on the Westfield datolite may be grouped according to their relative importance as follows:

1. Forms practically always present as large and important faces: $a(100), m_{\mathrm{x}}$ (011), $g(012), x(102), \epsilon$ (112).

2. Forms practically always present as smaller faces but sometimes large: $b$ (010), $c$ (001), $m$ (110), $n$ (111), $\mu$ (114), $\lambda$ (113).

3 . Forms frequently present as small faces: $t$ (013), $v$ (103), $u$ (104), $o$ (120), $r$ (230), $\sigma$ (014), $\beta$ (121), $Q$ (122), $U$ (123), $\nu$ (111), D (223),

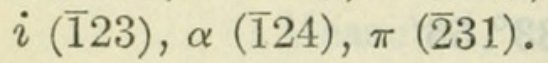


4. Forms occasionally or rarely present, including all other forms listed:

\section{TABLe 3.-Datolite.}

Comparison of average measured angles with calculated angles for previously described forms observed on datolite from Westfield during the present examination. Dana orientation.

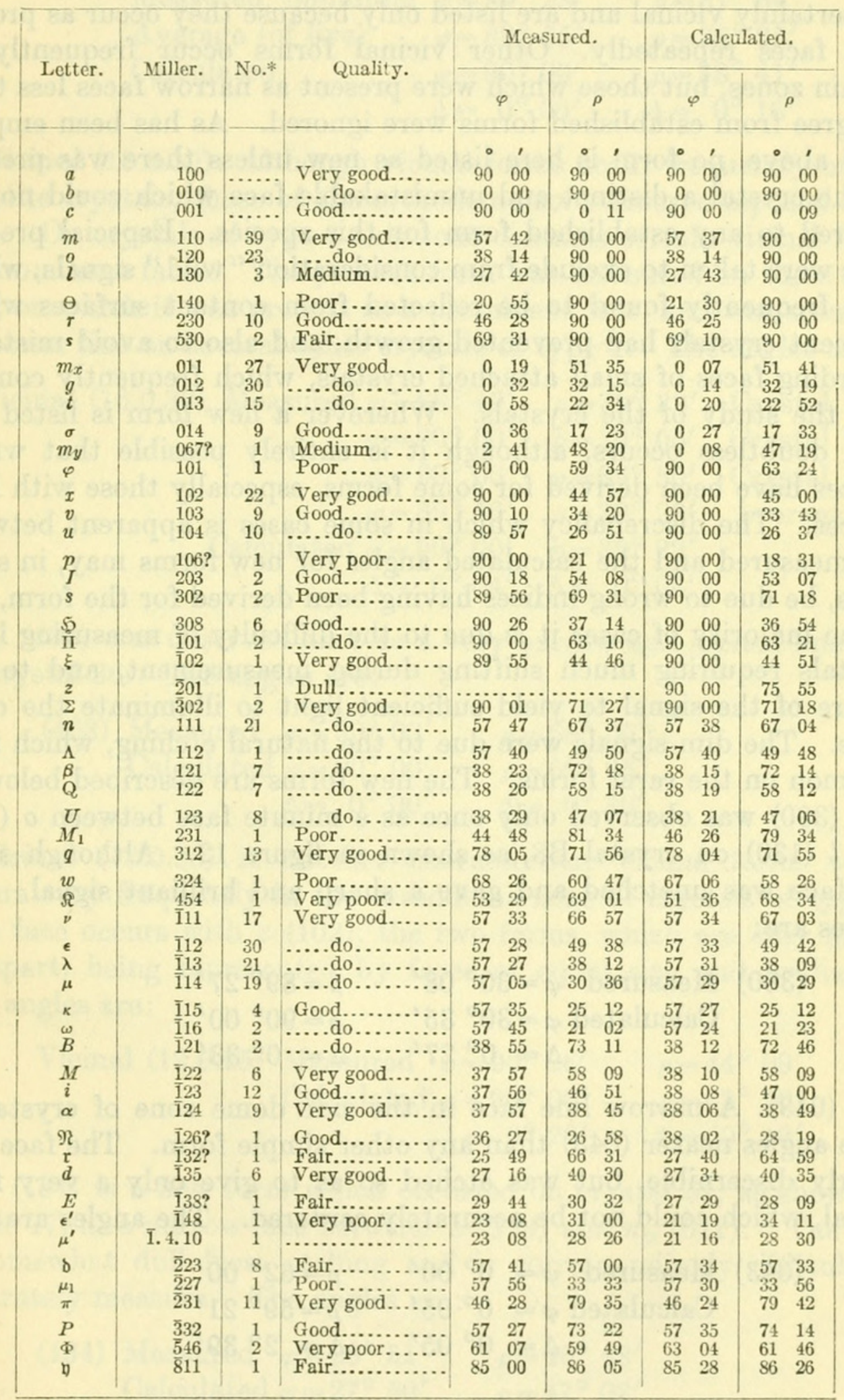

* Number of measurements included in the average. 


\section{NEW FORMS.}

Forty-six forms are listed below as new to the species datolite. Some of these, it is true, are open to criticism, inasmuch as the indices are high and seem somewhat irrational, while the greater number of the forms were observed but once or twice each. Two are certainly vicinal and are listed only because they occur as prominent faces repeatedly. Other vicinal forms occur frequently in certain zones, but those which were present as narrow faces less than a degree from established forms were ignored. As has been emphasized above, no form is here listed as new unless there was present on the crystal a distinct and unmistakable face which could not be referred to any established form for this species. Especial precautions were taken to exclude from consideration "wild" signals, which were frequently found to be reflected from contact surfaces where adjacent crystals had prevented growth, and also to avoid mistakes regarding faces of small attached crystals, which frequently complicate the study of the crystals. Wherever a new form is listed one such doubtless occurs, although it is entirely possible that wrong indices have been derived for some forms, especially those with high indices. The discrepancy which in some cases is apparent between the measured and the calculated angles for new forms may, in some cases, be due to wrong indices having been derived for the form, but in the majority of cases it is due to the difficulty of measuring large crystals requiring much shifting during measurement, and to the failure of the signal to yield sufficient light to illuminate the cross hairs. The dim signals were due to the natural etching, which is so common on the rarer forms. The new forms are described below:

(5 (380) was observed only once as a minute face between $o$ (120) and $l(130)$ on crystal B8, as shown in figure 12. Although small the face was unetched and gave a sharp and brilliant signal. The angles are:

$$
\begin{aligned}
\text { Measured } \varphi & =30^{\circ} 08^{\prime} & \rho & =89^{\circ} 27^{\prime} \\
\text { Calculated } \varphi & =30^{\circ} 35^{\prime} & \rho & =90^{\circ} 00^{\prime} \\
\Delta & =0^{\circ} 27^{\prime} & \Delta & =0^{\circ} 33^{\prime}
\end{aligned}
$$

$\Im$ (043). A narrow line face in the side dome zone of crystal 55 gave angles nearer (043) than any other simple form. The face was clearly discernible, but was etched so as to give only a very faint signal, which could not be accurately centered. The angles are:

$$
\begin{aligned}
\text { Measured } \varphi & =0^{\circ} 00^{\prime} & & \rho=62^{\circ} 00^{\prime} \\
\text { Calculated } \varphi & =0^{\circ} 05^{\prime} & & \rho=59^{\circ} 21^{\prime} \\
\Delta & =0^{\circ} 05^{\prime} & \Delta & =2^{\circ} 39^{\prime}
\end{aligned}
$$


$\{$ (205) was observed on five crystals as well-defined faces yielding good measurements. It is among the best established of the forms added here. The form is shown typically in crystals 10 (fig. 16), B8 (fig. 11), and 28 (fig. 8). The angles are as follows:

(205)

$$
\begin{array}{lll}
\text { Measured, maximum } \varphi=90^{\circ} 13^{\prime} & \rho=39^{\circ} 20^{\prime} \\
\text { Measured, minimum } \varphi=89^{\circ} 28^{\prime} & \rho=37^{\circ} 54^{\prime} \\
\text { Average (of five) } & \varphi=89^{\circ} 55^{\prime} & \rho=38^{\circ} 25^{\prime} \\
\text { Calculated } & \varphi=90^{\circ} 00^{\prime} & \rho=38^{\circ} 41^{\prime} \\
\Delta & \Delta=0^{\circ} 05^{\prime} & \Delta=0^{\circ} 16^{\prime}
\end{array}
$$

Vicinal (16.0.39). Although vicinal forms occur frequently on the datolite crystals, those of the orthodome zone deserve especial mention. On crystals of type 4 this zone contains certain vicinal forms as prominent faces. The present form was measured on three crystals, on which it was present as a prominent face, and was seen as a narrower line on several other crystals of type 4 . The angles are:

Vicinal (16.0.39) Measured $\varphi=89^{\circ} 49^{\prime} \quad \rho=39^{\circ} 22^{\prime} \quad$ Crystal B4.

$$
\begin{aligned}
& \varphi=90^{\circ} 00^{\prime} \quad \rho=39^{\circ} 05^{\prime} \quad \text { Crystal B5. } \\
& \varphi=90^{\circ} 00^{\prime} \quad \rho=39^{\circ} 50^{\prime} \quad \text { Crystal } 10 . \\
& \varphi=89^{\circ} 56^{\prime} \quad \rho=39^{\circ} 26^{\prime} \quad \text { Average. } \\
& \text { Calculated } \varphi=90^{\circ} 00^{\prime} \quad \rho=39^{\circ} 22^{\prime} \\
& \Delta=0^{\circ} \cdot 04^{\prime} \quad \Delta=0^{\circ} 04^{\prime}
\end{aligned}
$$

$\mathfrak{M}$ (403) was observed once as a very narrow and etched line face on crystal 36 . The angles are:

$$
\begin{aligned}
\text { Measured } \varphi=90^{\circ} 00^{\prime} & \rho=68^{\circ} 55^{\prime} \\
\text { Calculated } \varphi=90^{\circ} 00^{\prime} & \rho=69^{\circ} 25^{\prime} \\
\Delta=0^{\circ} 00^{\prime} & \Delta=0^{\circ} 30^{\prime}
\end{aligned}
$$

Vicinal (12.0.25) is another characteristic vicinal form, which occurs very frequently in the orthodome zone of crystals of type 4 . This face occurs with $x$ (102), the two forms, which are only about $1^{\circ}$ apart, being represented by faces of equal size and brilliancy. The angles are:

$$
\begin{array}{rlrl}
\text { Vicinal (12.0.25) } & \text { Measured } \varphi=90^{\circ} 26^{\prime} & \rho=44^{\circ} 09^{\prime} \\
\text { Calculated } \varphi=90^{\circ} 00^{\prime} & \rho=43^{\circ} 50^{\prime} \\
\Delta=0^{\circ} 26^{\prime} & \Delta=0^{\circ} 19^{\prime}
\end{array}
$$

5 (134) is a new form which occurred on crystal 51, as shown in figure 17 , as a narrow face between $U(123)$ and $m_{x}$ (011). The face is somewhat dull from etching and is correspondingly difficult to accurately measure. The angles are:

(134)

$$
\begin{aligned}
\text { Measured } \varphi & =28^{\circ} 51^{\prime} & & \rho=46^{\circ} 48^{\prime} \\
\text { Calculated } \varphi & =27^{\circ} 50^{\prime} & \rho & =47^{\circ} 02^{\prime} \\
\Delta & =1^{\circ} 01^{\prime} & \Delta & =0^{\circ} 14^{\prime}
\end{aligned}
$$


$\mathfrak{P}$ (192) is considered to be one of the best established of the forms here listed as new. It occurs as sharp and brilliant, though small, faces and yields excellent signals. The habit and position of the form are shown on crystal B7 (fig. 10) and crystal B8 (fig. 12). The angles are:

(192)

$$
\begin{aligned}
& \text { Measured, minimum } \varphi=9^{\circ} 57^{\prime} \quad \rho=80^{\circ} 11^{\prime} \text { * } \\
& \text { Measured, maximum } \varphi=10^{\circ} 01^{\prime} \quad \rho=80^{\circ} 17^{\prime} \\
& \text { Measured, average } \quad \varphi=9^{\circ} 58^{\prime} \quad \rho=80^{\circ} 13^{\prime} \\
& \text { Calculated } \quad \varphi=9^{\circ} 57^{\prime} \quad \rho=80^{\circ} 12^{\prime} \\
& \Delta=0^{\circ} 01^{\prime} \quad \Delta=0^{\circ} 01^{\prime}
\end{aligned}
$$

$\mathfrak{Q}(1.10 .2)$, like (192), which it always accompanies, is a wellsubstantiated form observed as bright faces yielding sharp signals on several crystals. The angles are:

$\begin{array}{lll}\text { (1.10.2) } & \text { Measured, maximum } \varphi=9^{\circ} 10^{\prime} & \rho=81^{\circ} 06^{\prime} \\ \text { Measured, minimum } \varphi=9^{\circ} 08^{\prime} & \rho=81^{\circ} 04^{\prime} \\ \text { Measured, average } \varphi=9^{\circ} 09^{\prime} & \rho=81^{\circ} 05^{\prime} \\ \text { Calculated } & \varphi=9^{\circ} 08^{\prime} & \rho=81^{\circ} 01^{\prime} \\ & \Delta=0^{\circ} 01^{\prime} & \Delta=0^{\circ} 04^{\prime}\end{array}$

The two forms (192) and (1.10.2) occur together, and the differences in their angles are so small that the signals overlap slightly.

$\Re(1.12 .2)$ occurred as two fairly large, though etched, faces on crystal 14. The angles are:

(1.12.2) Measured $\varphi=7^{\circ} 35^{\prime} \quad \rho=83^{\circ} 18^{\prime}$ (average of 2).

$$
\text { Calculated } \begin{aligned}
\varphi & =7^{\circ} 30^{\prime} & & \rho=82^{\circ} 34^{\prime} \\
\Delta & =0^{\circ} 05^{\prime} & \Delta & =0^{\circ} 44^{\prime}
\end{aligned}
$$

ऽ (331), new, is one of the few positive pyramids occurring in the zone (001):(110). It occurs as a narrow line face, with $i$ (11.11.10) between (110) and (111), on crystal B6, and as a similar narrow, though distinct, face yielding a poor signal on crystal 55. The angles are:

(331)

$$
\begin{array}{rlrl}
\text { Measured } \varphi & =57^{\circ} 34^{\prime} & \rho=81^{\circ} 58^{\prime} & \text { Crystal B6. } \\
\text { Calculated } \varphi=57^{\circ} 37^{\prime} & \rho=81^{\circ} 42^{\prime} & \\
\Delta & =0^{\circ} 17^{\prime} & \Delta=0^{\circ} 16^{\prime} & \\
\text { Measured } \varphi & =57^{\circ} 29^{\prime} & \rho=80^{\circ} 37^{\prime} & \text { Crystal } 55 . \\
\Delta & =0^{\circ} 08^{\prime} & \Delta=1^{\circ} 05^{\prime} &
\end{array}
$$

I (343) was found as a very narrow but bright face, beveling the angle between $\beta$ (121) and $n$ (111) on crystal 51, as shown in figure 17 . Here it occurs with the other forms of the same vertical zonenamely, (344) and (345). The angles are:

$\begin{aligned} \text { (343) Measured } \varphi & =48^{\circ} 30^{\prime} & & \rho=69^{\circ} 13^{\prime} \\ \text { Calculated } \varphi & =49^{\circ} 49^{\prime} & \rho & =69^{\circ} 04^{\prime} \\ \Delta & =1^{\circ} 19^{\prime} & \Delta & =0^{\circ} 09^{\prime}\end{aligned}$


$\mathfrak{u}$ (344) occurred on crystal 51 as a very narrow face, beveling the edge between $n$ (111) and $Q$ (122), as shown in figure 17 . The face was bright but very narrow and gave a faint signal. The angles are:

(344)

$$
\begin{aligned}
\text { Measured } \varphi & =49^{\circ} 24^{\prime} \\
\text { Calculated } \varphi & =49^{\circ} 49^{\prime} \\
\Delta & =0^{\circ} 25^{\prime}
\end{aligned}
$$

$$
\begin{aligned}
& \rho=63^{\circ} 18^{\prime} \\
& \rho=63^{\circ} 00^{\prime} \\
& \Delta=0^{\circ} 18^{\prime}
\end{aligned}
$$

The same form was noted on two other crystals, but the faces were entirely dull, yielding no signals. These were identified by their zonal relations.

$\mathfrak{B}$ (345). A narrow line face, occurring with (343) and (344) on crystal 51, gave a distinct signal, which, however, was so faint that it could not be accurately measured. The form indicated by the angles measured is (10.12.15). The position of the form, however, shows the true indices to be (345), the discrepancy in the angles being due to inexact measurement. The angles are given as follows:

$$
\begin{aligned}
\text { (345) Measured } & \varphi=52^{\circ} 49^{\prime} & \rho=59^{\circ} 01^{\prime} \\
\text { (345) Calculated } & \varphi=49^{\circ} 50^{\prime} & \rho=57^{\circ} 30^{\prime} \\
\Delta & =2^{\circ} 59^{\prime} & \Delta=1^{\circ} 31^{\prime} \\
\text { (10.12.15) Calculated } \varphi & =52^{\circ} 46^{\prime} & \rho=59^{\circ} 08^{\prime} \\
\Delta & =0^{\circ} 03^{\prime} & \Delta=0^{\circ} 07^{\prime}
\end{aligned}
$$

The true indices of this form are thus somewhat in doubt.

W (382) occurred once as a very narrow and somewhat etched face, beveling the angle between $o(120)$ and $m_{\mathrm{x}}(011)$ on crystal B8, as shown in figure 12. The dim signal could not be accurately centered, thus giving very inaccurate measurements, as shown below:

(382) Measured $\varphi=30^{\circ} 38^{\prime} \quad \rho=82^{\circ} 36^{\prime}$

$$
\text { Calculated } \begin{aligned}
\varphi & =30^{\circ} 37^{\prime} & \rho & =80^{\circ} 21^{\prime} \\
\Delta & =0^{\circ} 01^{\prime} & \Delta & =2^{\circ} 15^{\prime}
\end{aligned}
$$

$\chi(455)$ occurred on crystal 14 as a narrow and somewhat etched face between $n$ (111) and $m_{\mathbf{x}}$ (011). The angles are:

(455)

$$
\begin{aligned}
\text { Measured } \varphi & =52^{\circ} 27^{\prime} & & \rho=64^{\circ} 13^{\prime} \\
\text { Calculated } \varphi & =51^{\circ} 38^{\prime} & \rho & =63^{\circ} 52^{\prime} \\
\Delta & =0^{\circ} 49^{\prime} & \Delta & =0^{\circ} 21^{\prime}
\end{aligned}
$$

V) (6.15.2) is one of the forms which is of more or less doubtful validity. It occurred on crystal 10 as a somewhat curved and etched face between $m_{x}(011)$ and $o$ (120), as shown in figure 19. The angles are:

$$
\begin{aligned}
& \text { (6.15.2) Measured } \varphi=33^{\circ} 55^{\prime} \quad \rho=84^{\circ} 51^{\prime} \\
& \text { Calculated } \varphi=32^{\circ} 14^{\prime} \quad \rho=84^{\circ} 54^{\prime} \\
& \Delta=1^{\circ} 41^{\prime} \quad \Delta=0^{\circ} 03^{\prime}
\end{aligned}
$$


3 (766) occurred as a small face yielding a sharp signal on crystal B 6. The angles are:

$\begin{aligned} \text { (766) Measured } \varphi & =61^{\circ} 45^{\prime} & & \rho=69^{\circ} 12^{\prime} \\ \text { Calculated } \varphi & =61^{\circ} 29^{\prime} & & \rho=69^{\circ} 20^{\prime} \\ \Delta & =0^{\circ} 16^{\prime} & \Delta & =0^{\circ} 08^{\prime}\end{aligned}$

The form, although it occurred only once as a measurable face, is believed well established.

h (768) occurred once only as a small and somewhat etched face on crystal B 9 . Its angles are:

(768) Measured $\varphi=61^{\circ} 24^{\prime} \quad \rho=62^{\circ} 44^{\prime}$

Calculated $\varphi=61^{\circ} 30^{\prime} \quad \rho=63^{\circ} 19^{\prime}$

$$
\Delta=0^{\circ} 06^{\prime} \quad \Delta=0^{\circ} 35^{\prime}
$$

The order of agreement between the measured and calculated angles is satisfactory, although the form needs confirmation.

$i$ (11.11.10) occurred as a narrow line face with 331 between $m$ (110) and $n$ (111) $\mathrm{n}$ crystal $\mathrm{B} 6$. While this might be considered a form vicinal to $n$ (111), the signals from the two faces are separated by almost $2^{\circ}$, as shown below:

$\begin{array}{rlrl}\text { (11.11.10) } & \text { Measured } \varphi=57^{\circ} 44^{\prime} & \rho=69^{\circ} 01^{\prime} \\ \text { Calculated } \varphi=57^{\circ} 38^{\prime} & \rho=68^{\circ} 58^{\prime} \\ \Delta & =0^{\circ} 06^{\prime} & \Delta=0^{\circ} 03^{\prime} \\ \text { (111) Calculated } \varphi & =57^{\circ} 38^{\prime} & \rho & =67^{\circ} 04^{\prime} \\ \Delta & =0^{\circ} 06^{\prime} & \Delta & =1^{\circ} 57^{\prime}\end{array}$

$\mathfrak{f}$ (142) occurs as a well-defined face on crystal 41 , as shown in figure 18. Although small, this face gave an excellent signal, yielding the angles:

$$
\begin{aligned}
\text { (142) Measured } \varphi & =21^{\circ} 22^{\prime} & \rho & =69^{\circ} 38^{\prime} \\
\text { Calculated } \varphi & =21^{\circ} 25^{\prime} & \rho & =69^{\circ} 51^{\prime} \\
\Delta & =0^{\circ} 03^{\prime} & \Delta & =0^{\circ} 13^{\prime}
\end{aligned}
$$

The same form occurred also on crystal 10 as a narrow face with (132) between $b$ (010) and $M(\overline{1} 22)$, as shown in figure 19 . The signal from this face, which was very narrow and etched, was too dim to be accurately measured. The angles it gave are:

$$
\begin{aligned}
& \text { (142) Measured } \varphi=23^{\circ} 25^{\prime} \quad \rho=68^{\circ} 20^{\prime} \quad \text { Crystal } 10 \\
& \Delta=2^{\circ} 00^{\prime} \quad \Delta=1^{\circ} 31^{\prime}
\end{aligned}
$$

$f(143)$ occurred as a single face on crystal 41, as shown in figure 18. Although small, this face was bright and gave a good signal. The angles are:

$$
\begin{aligned}
\text { Measured } \varphi & =21^{\circ} 51^{\prime} & & \rho=61^{\circ} 25^{\prime} \\
\text { Calculated } \varphi & =21^{\circ} 26^{\prime} & \rho & =61^{\circ} 07^{\prime} \\
\Delta & =0^{\circ} 25^{\prime} & \Delta & =0^{\circ} 18^{\prime}
\end{aligned}
$$


The agreement is good, and although observed only once, this is considered a well-grounded form.

$\mathfrak{l}(\overline{1} 67)$ occurs on crystal 10 as a narrow face between $i(\overline{1} 23)$ and $m_{x}$ (011), as shown in figure 16 . The face is partly dulled by etching and yields a dim signal giving the following angles:

(167)

$$
\begin{aligned}
\text { Measured } \varphi & =15^{\circ} 22^{\prime} & & \rho=48^{\circ} 18^{\prime} \\
\text { Calculated } \varphi & =14^{\circ} 36^{\prime} & \rho & =48^{\circ} 16^{\prime} \\
\Delta & =0^{\circ} 46^{\prime} & \Delta & =0^{\circ} 02^{\prime}
\end{aligned}
$$

Although the values for $\Delta$ are small, the form was not confirmed by measurement of any other crystals, and, since it does not fit in a normal series as shown in the following discussion of zones, it must be considered to be doubtful.

$\mathfrak{m}$ (1.6.12) occurred as a narrow line face, beveling the angle between $g(012)$ and $\mu$ ( 114$)$ on crystal 55 . The face, although fairly conspicuous, was etched and rounded so as to yield only a poor signal, which, owing to its dimness, could not be accurately measured. The angles are:

$$
\begin{aligned}
\text { (1.6.12) Measured } \varphi=15^{\circ} 14^{\prime} & \rho=30^{\circ} 06^{\prime} \\
\text { Calculated } \varphi=14^{\circ} 30^{\prime} & \rho=33^{\circ} 11^{\prime} \\
\Delta=0^{\circ} 44^{\prime} & \Delta=3^{\circ} 05^{\prime}
\end{aligned}
$$

There is a marked probability that the indices have been incorrectly determined.

o (1.6.14) occurred with the last as a distinct but rounded face, beveling the angle between $g(012)$ and $\kappa(115)$ on crystal 55 . The signal was dim and somewhat blurred. The angles are:

$$
\begin{array}{rlrl}
\text { (1.6.14) } & \text { Measured } \varphi=15^{\circ} 05^{\prime} & \rho=27^{\circ} 49^{\prime} \\
\text { Calculated } \varphi=14^{\circ} 28^{\prime} & \rho=29^{\circ} 16^{\prime} \\
\Delta=0^{\circ} 37^{\prime} & \Delta=1^{\circ} 27^{\prime}
\end{array}
$$

This form also must be regarded as requiring further confirmation. $p$ (1.10.30) occurred as a dim face, beveling the angle between $t(013)$ and $\kappa(\overline{1} 15)$ adjacent to $\mu(\overline{1} .6 .12)$ and $p(\overline{1} .6 .14)$ on crystal 55. Like these forms the face, though a relatively broad and prominent line, is somewhat etched and rounded, although this is the best established of the three forms, as shown by its angles, which are as follows:

$$
\begin{aligned}
& \text { (1.10.30) Measured } \varphi=8^{\circ} 06^{\prime} \quad \rho=22^{\circ} 42^{\prime} \\
& \text { Calculated } \varphi=8^{\circ} 38^{\prime} \quad \rho=23^{\circ} 05^{\prime} \\
& \Delta=0^{\circ} 32^{\prime} \quad \Delta=0^{\circ} 23^{\prime}
\end{aligned}
$$


$\&$ (1.12.10) occurred on crystal 10 as a small though bright face, as shown in figure 19 . The angles are:

$$
\begin{array}{rlrl}
\text { (1.12.10) } & \text { Measured } \varphi=7^{\circ} 25^{\prime} & \rho=56^{\circ} 15^{\prime} \\
\text { Calculated } \varphi=7^{\circ} 23^{\prime} & \rho=56^{\circ} 53^{\prime} \\
\Delta=0^{\circ} 02^{\prime} & \Delta=0^{\circ} 38^{\prime}
\end{array}
$$

The order of agreement is good, and this is regarded as a wellestablished form.

$\mathrm{t}(1.20 .15)$ occurs on crystal B7, as shown in figure 10 , as a small triangular face. The angles are:

$$
\begin{aligned}
& \text { (1.20.15) Measured } \varphi=4^{\circ} 51^{\prime} \quad \rho=58^{\circ} 50^{\prime} \\
& \text { Calculated } \varphi=4^{\circ} 25^{\prime} \quad \rho=59^{\circ} 27^{\prime} \\
& \Delta=0^{\circ} 26^{\prime} \quad \Delta=0^{\circ} 37^{\prime}
\end{aligned}
$$

ut (211) occurs on several crystals as a narrow face between $\nu$ (111) and $a$ (100). In most instances, however, the face is entirely dull and can not be measured. The best face of this form which occurred on crystal 44, shown in part in figure 20 , gave the following angles:

$\begin{aligned} \text { (211) Measured } \varphi & =71^{\circ} 41^{\prime} & & \rho=76^{\circ} 03^{\prime} \\ \text { Calculated } \varphi & =72^{\circ} 25^{\prime} & & \rho=76^{\circ} 34^{\prime} \\ \Delta & =0^{\circ} 44^{\prime} & \Delta & =0^{\circ} 31^{\prime}\end{aligned}$

Although the agreement between the calculated and measured angles is not as close as might be expected, this is due to the faintness of the signal from the etched face. The form may be regarded as well grounded.

x (229) was noted first upon crystal 41 , shown in figure 18 , as a narrow line face between $\mu$ (114) and $\kappa(115)$. The angles are as follows:

(229)

$$
\begin{array}{rlrl}
\text { Measured } \varphi & =58^{\circ} 04^{\prime} & \rho=27^{\circ} 33^{\prime} \\
\text { Calculated } \varphi=57^{\circ} 28^{\prime} & \rho=27^{\circ} 36^{\prime} \\
\Delta & =0^{\circ} 36^{\prime} & \Delta=0^{\circ} 03^{\prime}
\end{array}
$$

The same form was also noted on crystal 55 as an etched face which gave very poor signals, not accurately measurable because of their faintness. These gave the angles:

$$
\begin{aligned}
(\overline{2} 29) \text { Measured } \varphi & =55^{\circ} 40^{\prime} & & \rho=25^{\circ} 08^{\prime} \\
\Delta & =1^{\circ} 48^{\prime} & \Delta & =2^{\circ} 28^{\prime}
\end{aligned}
$$

Since the form does not agree with the normal series as shown in the discussion of zone 4 below, it must be regarded as a disturbed form. 
$z$ (263) occurred on crystal 41 as a somewhat rounded face yielding a close group of signals. The face is shown in figure 18 . It gave the angles:

$$
\begin{array}{rlrl}
\text { Measured } \varphi=28^{\circ} 55^{\prime} & & \rho=70^{\circ} 15^{\prime} \\
\text { Calculated } \varphi & =27^{\circ} 37^{\prime} & \rho & =70^{\circ} 45^{\prime} \\
\Delta & =1^{\circ} 18^{\prime} & \Delta & =0^{\circ} 30^{\prime}
\end{array}
$$

This form fits normally in the zone as shown below, and since it is an entirely probable form it may be considered established. The same form occurred on crystal B 7 as a narrow face between $\Omega(1.10 .2)$ and $M$ (122). This occurrence of the form yielded a somewhat better signal, giving the angles:

$$
\begin{aligned}
& \text { (263) Measured } \varphi=27^{\circ} 57^{\prime} \quad \rho=70^{\circ} 44^{\prime} \\
& \Delta=0^{\circ} 20^{\prime} \quad \Delta=0^{\circ} 01^{\prime}
\end{aligned}
$$

$\theta(\overline{2} 95)$ occurred as one of a small group of rare forms on crystal 41 as shown in figure 18 . The face of $\overline{2} 95$, though small, gave a sharp though faint signal, furnishing the angles:

$$
\begin{aligned}
& \text { (295) Measured } \varphi=18^{\circ} 54^{\prime} \quad \rho=67^{\circ} 00^{\prime} \\
& \text { Calculated } \varphi=19^{\circ} 15^{\prime} \quad \rho=67^{\circ} 29^{\prime} \\
& \Delta=0^{\circ} 21^{\prime} \quad \Delta=0^{\circ} 29^{\prime}
\end{aligned}
$$

૪ (296) occurred on crystal 41 as a small face, as shown in figure 18, which gave a distinct signal, although, owing to the minuteness of the face, the signal was too faint to illuminate the cross hairs. The angles on this crystal were:

$$
\begin{aligned}
\text { (296) Measured } \varphi & =19^{\circ} 39^{\prime} & \rho & =65^{\circ} 32^{\prime} \\
\text { Calculated } \varphi & =19^{\circ} 14^{\prime} & \rho & =63^{\circ} 34^{\prime} \\
\Delta & =0^{\circ} 25^{\prime} & \Delta & =1^{\circ} 58^{\prime}
\end{aligned}
$$

The same form occurred on crystal 10 as a narrow face between $i$ (123) and $b(010)$, as shown in figure 19. This gave a somewhat brighter and more accurately measurable signal than the last, yielding the following angles:

$$
\begin{aligned}
(\overline{2} 96) \text { Measured } \varphi & =18^{\circ} 50^{\prime} & \rho & =63^{\circ} 54^{\prime} \\
\Delta & =0^{\circ} 24^{\prime} & \Delta & =0^{\circ} 20^{\prime}
\end{aligned}
$$

The measurements of the two crystals are averaged in Table 5 . $\dot{\rho}(\overline{2} .10 .5)$ occurred on crystal 41 , as shown in figure 18 , as a minute face giving a signal too dim to be accurately centered. The angles are: 


$\begin{array}{rlrl}\text { (2.10.5) Measured } \varphi & =18^{\circ} 41^{\prime} & \rho=69^{\circ} 41^{\prime} \\ \text { Calculated } \varphi=17^{\circ} 24^{\prime} & \rho=69^{\circ} 24^{\prime} \\ \Delta & =1^{\circ} 17^{\prime} & \Delta=0^{\circ} 17^{\prime}\end{array}$

This form therefore is poorly established by the data obtained. $x_{1}(342)$ occurred on crystal 27 as a small brilliant face yielding an excellent signal. The angles are:

$$
\begin{aligned}
\text { Measured } \varphi & =49^{\circ} 04^{\prime} & & \rho=75^{\circ} 41^{\prime} \\
\text { Calculated } \phi & =49^{\circ} 45^{\prime} & \rho & =75^{\circ} 41^{\prime} \\
\Delta & =0^{\circ} 41^{\prime} & \Delta & =0^{\circ} 00^{\prime}
\end{aligned}
$$

Although observed only once, the form is considered to be well established.

6 (343) occurs on crystal 33 as a distinct though narrow line face between $\pi(\overline{2} 31)$ and $\epsilon$ (112), as shown in figure 24 . The signal, owing to the narrowness of the face, was too faint for precise measurement. The angles measured are:

$$
\begin{aligned}
\text { Measured } \varphi & =49^{\circ} 36^{\prime} & \rho & =70^{\circ} 29^{\prime} \\
\text { Calculated } \varphi & =49^{\circ} 45^{\prime} & \rho & =69^{\circ} 03^{\prime} \\
\Delta & =0^{\circ} 09^{\prime} & \Delta & =1^{\circ} 26^{\prime}
\end{aligned}
$$

The form is normal in zone No. 12, as shown below, and is considered as established, the indices being confirmed by zonal relations. $\Upsilon(\overline{3} 51)$ occurred on crystal 33 , as shown in figure 24 , as a distinct line face between $\pi(231)$ and $o(120)$. The very faint signal from the partially etched face gave as angles:

$$
\begin{aligned}
(\overline{3} 51) \text { Measured } \varphi & =42^{\circ} 32^{\prime} & & \rho=83^{\circ} 45^{\prime} \\
\text { Calculated } \varphi & =43^{\circ} 17^{\prime} & \rho & =83^{\circ} 26^{\prime} \\
\Delta & =0^{\circ} 45^{\prime} & \Delta & =0^{\circ} 19^{\prime}
\end{aligned}
$$

$e_{1}(\overline{3} 53)$ occurred on crystal 33 , as shown in figure 24 , as a small and very much etched face. The signal was very faint, and the measurements are only approximate. The angles are:

$$
\begin{aligned}
\text { (3553) Measured } \varphi & =44^{\circ} 20^{\prime} & & \rho=68^{\circ} 58^{\prime} \\
\text { Calculated } \varphi & =43^{\circ} 23^{\prime} & \rho & =73^{\circ} 58^{\prime} \\
\Delta & =0^{\circ} 57^{\prime} & \Delta & =5^{\circ} 00^{\prime}
\end{aligned}
$$

The large discrepancy, $\Delta=5^{\circ} 00^{\prime}$, is attributed to the difficulty of measuring so badly etched a face. The indices are confirmed by the zonal relations. 
$f_{1}(\overline{3} 61)$ occurred as a narrow line, giving a faint though distinct signal on crystal B2 between $o(120)$ and $M(\overline{1} 22)$. The angles measured are:

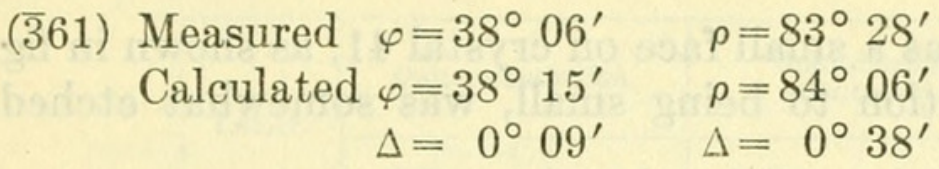

The form is considered to be well established.

$g_{1}(\overline{3} 62)$ occurred as a line face yielding a fair signal on crystal 10 , as shown in figure 19. The angles are:

$$
\begin{aligned}
& \text { (362) Measured } \varphi=37^{\circ} 55^{\prime} \quad \rho=78^{\circ} 35^{\prime} \\
& \text { Calculated } \varphi=38^{\circ} 13^{\prime} \quad \rho=78^{\circ} 19^{\prime} \\
& \Delta=0^{\circ} 18^{\prime} \quad \Delta=0^{\circ} 16^{\prime}
\end{aligned}
$$

This form also is normal in the zone (001): (120) and is considered to be well grounded.

\begin{tabular}{|c|c|c|}
\hline 1 & Measured $\varphi=25^{\circ} 03^{\prime}$ & $=34^{\circ} 5$ \\
\hline & Calculated $\varphi=25^{\circ} 30^{\prime}$ & $\rho=35^{\circ}$ \\
\hline & $\begin{aligned} \Delta & =0^{\circ} 27^{\prime}\end{aligned}$ & $\Delta=$ \\
\hline & $\Delta=2^{\circ} 29^{\prime}$ & $\Delta=0$ \\
\hline
\end{tabular}

$h_{1}(\overline{3} .10 .20)$ occurred on crystal B2 as a bright line yielding a fair signal between $\alpha$ (124) and $g(012)$. The angles are:

The form is near (136), as shown above, but not sufficiently near, the quality of the signal considered, to be assigned to that form As shown by its high indices and its zonal position, the form is "disturbed" and somewhat uncertainly established.

$i_{1}(\overline{4} 61)$ occurs as a distinct line face, giving a dim signal between $\pi$ (231) and $n$ (111), as shown in figure 24 . The angles are:

$$
\begin{aligned}
\text { (461) Measured } \varphi & =48^{\circ} 06^{\prime} & \rho & =84^{\circ} 55^{\prime} \\
\text { Calculated } \varphi & =46^{\circ} 26^{\prime} & \rho & =84^{\circ} 49^{\prime} \\
\Delta & =1^{\circ} 40^{\prime} & \Delta & =0^{\circ} 06^{\prime}
\end{aligned}
$$

$j_{1}(\overline{5} .6 .30)$ occurs on crystal B5 as a very narrow line face truncating the angle between $\mu$ (114) and \& (205), as shown in figure 13 . The angles are:

$$
\begin{aligned}
& \text { (5.6.30) Measured } \varphi=51^{\circ} 47^{\prime} \quad \rho=22^{\circ} 22^{\prime} \\
& \text { Calculated } \varphi=52^{\circ} 31^{\prime} \quad \rho=22^{\circ} 35^{\prime} \\
& \Delta=0^{\circ} 44^{\prime} \quad \Delta=0^{\circ} 13^{\prime}
\end{aligned}
$$


The indices are improbable and are not confirmed by the zonal relations or by the position of the form in the normal series, as shown below. This must consequently be considered a disturbed and abnormal form.

$k_{1}(794)$ occurs as a small face on crystal 41 , as shown in figure 18. The face, in addition to being small, was somewhat etched. The angles are:

(794)

$$
\begin{aligned}
\text { Measured } \varphi=50^{\circ} 11^{\prime} & \rho=77^{\circ} 12^{\prime} \\
\text { Calculated } \varphi=50^{\circ} 46^{\prime} & \rho=77^{\circ} 29^{\prime} \\
\Delta=0^{\circ} 35^{\prime} & \Delta=0^{\circ} 17^{\prime}
\end{aligned}
$$

This form also fails to fit in the normal series for its zone and is therefore a disturbed and abnormal form.

$l_{1}(9.16 .2)$ occurred on crystal 10 as a narrow rounded face between $o$ (120) and $\pi$ (231), as shown in figure 19. The angles measured are:

$$
\begin{aligned}
\text { (9.16.2) Measured } \varphi & =41^{\circ} 25^{\prime} & & \rho=85^{\circ} 47^{\prime} \\
\text { Calculated } \varphi & =41^{\circ} 33^{\prime} & \rho & =85^{\circ} 46^{\prime} \\
\Delta & =0^{\circ} 08^{\prime} & \Delta & =0^{\circ} 01^{\prime}
\end{aligned}
$$

The rounded face gave a band of signals. The measurement was made on a brighter and more pronounced signal in the center of the band. The form is poorly confirmed and is somewhat doubtful.

$m_{1}(\overline{12} .25 .1)$, a form with such high indices that it may almost be considered vicinal to $o$ (120) was observed as 7 distinct faces on 5 of the crystals examined. It is consequently believed to be a wellsubstantiated form. Of the crystals measured, Nos. 33 and B9 yielded the following angles:

(12.25.1)

$$
\begin{array}{lll}
\text { Measured, XI. } 33 & \varphi=37^{\circ} 11^{\prime} & \rho=88^{\circ} 33^{\prime} \\
\text { Measured, B9 } & \varphi=36^{\circ} 40^{\prime} & \rho=88^{\circ} 14^{\prime} \\
\text { Measured, B9 } & \varphi=36^{\circ} 44^{\prime} & \rho=88^{\circ} 18^{\prime} \\
\text { Measured, average } \varphi=36^{\circ} 52^{\prime} & \rho=88^{\circ} 22^{\prime} \\
\text { Calculated } & \varphi=37^{\circ} 07^{\prime} & \rho=88^{\circ} 27^{\prime} \\
& \Delta=0^{\circ} 15^{\prime} & \Delta=0^{\circ} 05^{\prime}
\end{array}
$$

This form occurs as a narrow line sometimes completely etched, beveling the edge between $o$ (120) and $m_{\Sigma}$ (011). 
Table 4.-Datolite.

List of new forms observed on datolite from Westfield during the present study with equivalent symbols and indices in the Dana and Goldschmidt orientations.

\begin{tabular}{|c|c|c|c|c|}
\hline \multirow{2}{*}{ Letter. } & \multicolumn{2}{|c|}{ Dana orientation. } & \multicolumn{2}{|c|}{$\begin{array}{l}\text { Goldschmidt } \\
\text { orientation. }\end{array}$} \\
\hline & Miller. & Symbol. & Miller. & Symbol. \\
\hline $\begin{array}{l}\mathfrak{c} \\
\mathfrak{g} \\
\mathbb{2}\end{array}$ & $\begin{array}{l}380 \\
013 \\
205\end{array}$ & $\begin{array}{rr}\infty & \frac{8}{3} \\
0 & \frac{4}{3} \\
\frac{2}{8} & 0\end{array}$ & $\begin{array}{l}083 \\
380 \\
504\end{array}$ & $\begin{array}{r}0 \frac{8}{3} \\
\infty 0 \\
+\quad 80\end{array}$ \\
\hline $\begin{array}{l}\text { Vic. } \\
\mathfrak{M} \\
\text { Vic. }\end{array}$ & $\begin{array}{r}16.0 .39 \\
403 \\
12.0 .25\end{array}$ & $\begin{array}{rl}+18 & 0 \\
+38 & 0 \\
+3 & 0 \\
+\frac{1}{2} 8 & 0\end{array}$ & $\begin{array}{r}39.0 .32 \\
302 \\
25.0 .24\end{array}$ & $\begin{aligned}+\frac{30}{30} & 0 \\
+\frac{3}{2} & 0 \\
+\frac{28}{24} & 0\end{aligned}$ \\
\hline $\begin{array}{l}\mathfrak{O} \\
\mathfrak{B} \\
\mathfrak{Q}\end{array}$ & $\begin{array}{r}134 \\
192 \\
1.10 .2\end{array}$ & 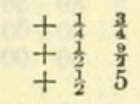 & $\begin{array}{r}231 \\
191 \\
1.10 .1\end{array}$ & $\begin{array}{l}+23 \\
+19 \\
+110\end{array}$ \\
\hline$\underset{\mathfrak{I}}{\mathfrak{I}}$ & $\begin{array}{r}1.12 .2 \\
331 \\
343\end{array}$ & $\begin{array}{l}+\frac{1}{2} 6 \\
+\quad 3 \\
+13\end{array}$ & $\begin{array}{r}1.12 .1 \\
166 \\
386\end{array}$ & $\begin{array}{l}+112 \\
+\frac{3}{6} \\
+\quad \frac{1}{2}\end{array}$ \\
\hline $\begin{array}{l}\mathfrak{M} \\
\mathfrak{B} \\
\mathfrak{W}\end{array}$ & $\begin{array}{l}344 \\
345 \\
382\end{array}$ & $\begin{array}{l}+\frac{3}{4} \\
+5 \\
+\frac{3}{5} \\
+\frac{5}{2}\end{array}$ & $\begin{array}{l}243 \\
586 \\
183\end{array}$ & $\begin{array}{l}+\frac{2}{3} \\
+\frac{4}{3} \\
+\frac{5}{3} \\
+\frac{1}{3} \\
+\frac{8}{3}\end{array}$ \\
\hline $\begin{array}{l}\mathfrak{x} \\
\mathfrak{D} \\
3\end{array}$ & $\begin{array}{r}455 \\
6.15 .2 \\
766\end{array}$ & $\begin{array}{r}+4 \\
+3 \\
+32 \\
+\quad 31 \\
+\quad 8\end{array}$ & $\begin{array}{r}5.10 .8 \\
1.15 .6 \\
367\end{array}$ & $\begin{array}{l}+\frac{8}{8} \\
+\frac{8}{4} \\
+\frac{1}{8} \\
+\frac{5}{7}\end{array}$ \\
\hline$\stackrel{\substack{\mathfrak{h} \\
i \\
i}}{i}$ & $\begin{array}{r}768 \\
11.11 .10 \\
\overline{1} 142\end{array}$ & $\begin{array}{l}+\frac{7}{8} \\
\pm \frac{3}{1} \\
\pm \frac{1}{1} \frac{1}{6}\end{array}$ & $\begin{array}{r}467 \\
5.11 .11 \\
\overline{1} 141\end{array}$ & $\begin{array}{ll}+\frac{4}{7} & 0 \\
+11 & 1 \\
-1 & 4\end{array}$ \\
\hline $\begin{array}{l}\mathrm{t} \\
\mathrm{l} \\
\mathrm{m}\end{array}$ & $\begin{array}{r}\overline{1} 43 \\
\overline{1} 67 \\
\text { I. } 6.12\end{array}$ & $\begin{array}{ll}-\frac{1}{3} & 4 \\
z & \frac{1}{3} \\
-\frac{1}{2} & \frac{7}{12} \\
-\frac{1}{2} & \frac{1}{2}\end{array}$ & $\begin{array}{r}\overline{3} 82 \\
7.12 .2 \\
661\end{array}$ & $\begin{array}{ll}-\frac{3}{2} & 4 \\
=\frac{7}{2} & 6 \\
-\quad & 6\end{array}$ \\
\hline $\begin{array}{l}0 \\
b \\
b \\
8\end{array}$ & $\begin{array}{r}1.6 .14 \\
1.10 .30 \\
1.12 .10\end{array}$ & $\begin{array}{ll}-x^{2} & \frac{3}{2} \\
-3^{2} & \frac{1}{3} \\
-\frac{1}{3} & \frac{8}{6}\end{array}$ & $\begin{array}{r}761 \\
15.10 .1 \\
5.12 .1\end{array}$ & $\begin{array}{r}-76 \\
-1510 \\
-512\end{array}$ \\
\hline $\begin{array}{l}t \\
\mathfrak{u} \\
\mathfrak{x}\end{array}$ & $\begin{array}{r}\text { 1. } 20.15 \\
\overline{2} 11 \\
\overline{2} 29\end{array}$ & $\begin{array}{ll}-\frac{1}{18} & 4 \\
-2 & 1 \\
-\quad & \frac{2}{3}\end{array}$ & $\begin{array}{r}15.40 .2 \\
\overline{124} \\
944\end{array}$ & 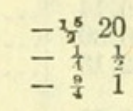 \\
\hline $\begin{array}{l}8 \\
\theta \\
\gamma\end{array}$ & $\begin{array}{l}\overline{2} 63 \\
\overline{2} 95 \\
296\end{array}$ & 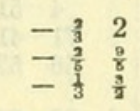 & $\begin{array}{r}\overline{3} .12 .4 \\
\text { 5. } 18.4 \\
\overline{3} 92\end{array}$ & 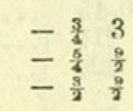 \\
\hline $\begin{array}{l}\dot{\rho} \\
x_{1} \\
\sigma\end{array}$ & $\begin{array}{r}2.10 .5 \\
\frac{342}{343}\end{array}$ & 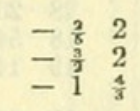 & $\begin{array}{r}5.20 .4 \\
143 \\
\overline{3} 86\end{array}$ & $\begin{array}{ll}-\frac{8}{4} & 5 \\
\overline{\frac{1}{3}} & \frac{1}{3} \\
-\frac{1}{2} & \frac{4}{3}\end{array}$ \\
\hline $\begin{array}{l}\Upsilon \\
e_{1} \\
f_{1}\end{array}$ & $\begin{array}{l}\overline{3} 51 \\
\overline{3} 53 \\
\overline{3} 61\end{array}$ & $\begin{array}{ll}-3 & 5 \\
-1 & 8 \\
-3 & 6\end{array}$ & $\begin{array}{l}\overline{1} \cdot 10.6 \\
\overline{3} .10 .9 \\
1.12 .6\end{array}$ & $\begin{array}{l}=\frac{1}{6} \frac{8}{3} \\
=\frac{3}{3} \\
-\frac{10}{6} \\
-\frac{1}{6}\end{array}$ \\
\hline $\begin{array}{l}g_{1} \\
h_{1} \\
i_{1}\end{array}$ & $\begin{array}{r}\overline{3} 62 \\
\overline{3} .10 .20 \\
\overline{4} 61\end{array}$ & $\begin{array}{ll}-\frac{3}{2} & 3 \\
-\frac{3}{20} & \frac{1}{2} \\
-4 & 6\end{array}$ & $\begin{array}{r}\overline{1} 63 \\
\overline{1} 0.10 .3 \\
\overline{1} .12 .8\end{array}$ & $\begin{array}{l}-\frac{1}{3} 2 \\
=\frac{10}{8} \\
-\frac{1}{8} \frac{3}{2}\end{array}$ \\
\hline $\begin{array}{l}j_{1} \\
k_{1} \\
l_{1}\end{array}$ & $\begin{array}{l}5.6 .30 \\
794 \\
\overline{9} .16 .2\end{array}$ & 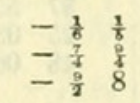 & $\begin{array}{l}\text { 15. } 6.5 \\
297 \\
\text { 1. } 16.9\end{array}$ & $\begin{array}{l}-3 \frac{8}{8} \\
=\frac{2}{8} \\
-\frac{1}{9} \frac{16}{6}\end{array}$ \\
\hline$m_{1}$ & $\overline{12 .} 25.1$ & -1225 & 1. 50.24 & $-\frac{1}{26} \frac{25}{12}$ \\
\hline
\end{tabular}


TABLe 5.-Datolite.

Cumparison of measured angles with calculated angles for new forms observed on datolite from Westfield, Massachusetts. Dana orientation.

\begin{tabular}{|c|c|c|c|c|c|c|c|c|c|c|}
\hline \multirow{2}{*}{ Letter. } & \multirow{2}{*}{ Miller. } & \multirow{2}{*}{ Quality. } & \multicolumn{4}{|c|}{ Measured. } & \multicolumn{4}{|c|}{ Calculated. } \\
\hline & & & $\varphi$ & & $\rho$ & & $\varphi$ & & $\rho$ & \\
\hline 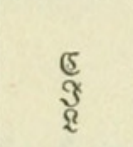 & $\begin{array}{l}380 \\
043 \\
205\end{array}$ & $\begin{array}{l}\text { Very good. } \\
\text { Poor....... } \\
\text { Very good. }\end{array}$ & $\begin{array}{r}\circ \\
30 \\
0 \\
89\end{array}$ & $\begin{array}{l}, \\
08 \\
00 \\
55\end{array}$ & & $\begin{array}{l}\text { ' } \\
27 \\
00 \\
25\end{array}$ & & $\begin{array}{l}\text { ' } \\
35 \\
05 \\
00\end{array}$ & & $\begin{array}{l}\text {, } \\
00 \\
21 \\
41\end{array}$ \\
\hline $\begin{array}{l}\text { Vic. } \\
\mathfrak{M} \\
\text { Vic. }\end{array}$ & $\begin{array}{r}16.0 .39 \\
403 \\
12.0 .25\end{array}$ & $\begin{array}{l}\text { Good......... } \\
\text { Poor...... } \\
\text { Very good... }\end{array}$ & $\begin{array}{l}89 \\
90 \\
90\end{array}$ & $\begin{array}{l}56 \\
00 \\
00\end{array}$ & & $\begin{array}{l}26 \\
55 \\
09\end{array}$ & $\begin{array}{l}90 \\
90 \\
90\end{array}$ & $\begin{array}{l}00 \\
00 \\
00\end{array}$ & & $\begin{array}{l}22 \\
25 \\
50\end{array}$ \\
\hline $\begin{array}{l}\mathfrak{O} \\
\mathfrak{Q} \\
\mathfrak{Q}\end{array}$ & $\begin{array}{r}134 \\
192 \\
1.10 .2\end{array}$ & $\begin{array}{l}\text { Fair..... } \\
\text { Very good } \\
\ldots \ldots \text { do .... }\end{array}$ & $\begin{array}{r}28 \\
9 \\
9\end{array}$ & $\begin{array}{l}51 \\
58 \\
08\end{array}$ & $\begin{array}{l}46 \\
80 \\
81\end{array}$ & $\begin{array}{l}48 \\
13 \\
04\end{array}$ & $\begin{array}{r}27 \\
9 \\
9\end{array}$ & $\begin{array}{l}50 \\
57 \\
06\end{array}$ & $\begin{array}{l}47 \\
80 \\
81\end{array}$ & $\begin{array}{l}02 \\
12 \\
01\end{array}$ \\
\hline$\stackrel{\Re}{\mathfrak{S}}$ & $\begin{array}{r}1.12 .2 \\
331 \\
343\end{array}$ & $\begin{array}{l}\text { Good....... } \\
\text { Very poor. }\end{array}$ & $\begin{array}{r}7 \\
57 \\
48\end{array}$ & $\begin{array}{l}35 \\
25 \\
30\end{array}$ & $\begin{array}{l}83 \\
\$ 1 \\
69\end{array}$ & $\begin{array}{l}18 \\
09 \\
13\end{array}$ & $\begin{array}{r}7 \\
57 \\
49\end{array}$ & $\begin{array}{l}30 \\
37 \\
49\end{array}$ & $\begin{array}{l}82 \\
81 \\
69\end{array}$ & $\begin{array}{l}34 \\
58 \\
04\end{array}$ \\
\hline $\begin{array}{l}\mathfrak{u} \\
\mathfrak{B} \\
\mathfrak{B}\end{array}$ & $\begin{array}{l}344 \\
345 \\
382\end{array}$ & $\begin{array}{l}\text { Good... } \\
\text { Poor... } \\
\ldots \ldots . . \text { do. }\end{array}$ & $\begin{array}{l}49 \\
52 \\
30\end{array}$ & $\begin{array}{l}24 \\
49 \\
38\end{array}$ & $\begin{array}{l}63 \\
59 \\
82\end{array}$ & $\begin{array}{l}18 \\
01 \\
36\end{array}$ & $\begin{array}{l}49 \\
49 \\
30\end{array}$ & $\begin{array}{l}49 \\
50 \\
37\end{array}$ & & $\begin{array}{l}00 \\
30 \\
21\end{array}$ \\
\hline $\begin{array}{l}x \\
\text { y } \\
3\end{array}$ & $\begin{array}{r}455 \\
6.15 .2 \\
766\end{array}$ & \begin{tabular}{l}
$\ldots$. do... \\
\hdashline$\ldots$ do... \\
Good....
\end{tabular} & $\begin{array}{l}52 \\
33 \\
61\end{array}$ & $\begin{array}{l}27 \\
55 \\
45\end{array}$ & $\begin{array}{l}64 \\
84 \\
69\end{array}$ & $\begin{array}{l}13 \\
51 \\
12\end{array}$ & $\begin{array}{l}51 \\
32 \\
61\end{array}$ & $\begin{array}{l}38 \\
14 \\
29\end{array}$ & $\begin{array}{l}63 \\
84 \\
69\end{array}$ & $\begin{array}{l}52 \\
54 \\
20\end{array}$ \\
\hline $\begin{array}{l}\mathfrak{b} \\
i \\
i\end{array}$ & $\begin{array}{r}768 \\
11.11 .10 \\
\text { I42 }\end{array}$ & $\begin{array}{l}\text { Poor........ } \\
\text { Fair........ } \\
\text { Very good... }\end{array}$ & $\begin{array}{l}61 \\
57 \\
22\end{array}$ & $\begin{array}{l}24 \\
44 \\
23\end{array}$ & $\begin{array}{l}62 \\
69 \\
68\end{array}$ & $\begin{array}{l}44 \\
01 \\
59\end{array}$ & $\begin{array}{l}61 \\
57 \\
21\end{array}$ & $\begin{array}{l}30 \\
38 \\
25\end{array}$ & $\begin{array}{l}63 \\
68 \\
69\end{array}$ & $\begin{array}{l}19 \\
58 \\
51\end{array}$ \\
\hline $\begin{array}{c}\mathrm{f} \\
\mathrm{l} \\
\mathrm{m}\end{array}$ & $\begin{array}{r}\overline{1} 43 \\
\overline{167} \\
\text { 1. } 6.12\end{array}$ & $\begin{array}{l}\text { Good.... } \\
\text { Poor.... } \\
\text {.....do.. }\end{array}$ & $\begin{array}{l}21 \\
15 \\
15\end{array}$ & $\begin{array}{l}51 \\
22 \\
14\end{array}$ & $\begin{array}{l}61 \\
48 \\
30\end{array}$ & $\begin{array}{l}25 \\
18 \\
06\end{array}$ & $\begin{array}{l}21 \\
14 \\
14\end{array}$ & $\begin{array}{l}26 \\
36 \\
30\end{array}$ & & $\begin{array}{l}07 \\
16 \\
11\end{array}$ \\
\hline $\begin{array}{l}0 \\
p \\
8\end{array}$ & $\begin{array}{l}\overline{1} .6 .14 \\
\text { I. } 10.30 \\
\text { 1. } 12.10\end{array}$ & $\begin{array}{l}\text {.....do } \\
\ldots . \text { do } \\
\ldots . \text {... }\end{array}$ & $\begin{array}{r}15 \\
8 \\
7\end{array}$ & $\begin{array}{l}05 \\
06 \\
25\end{array}$ & $\begin{array}{l}27 \\
22 \\
56\end{array}$ & $\begin{array}{l}49 \\
42 \\
15\end{array}$ & $\begin{array}{r}14 \\
8 \\
7\end{array}$ & $\begin{array}{l}28 \\
38 \\
23\end{array}$ & $\begin{array}{l}29 \\
23 \\
56\end{array}$ & $\begin{array}{l}16 \\
05 \\
53\end{array}$ \\
\hline$\underset{\mathfrak{u}}{t}$ & 1. $\begin{array}{r}20.15 \\
\overline{2} 11 \\
\overline{2} 29\end{array}$ & 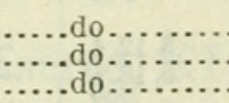 & $\begin{array}{r}4 \\
71 \\
56\end{array}$ & $\begin{array}{l}51 \\
41 \\
52\end{array}$ & $\begin{array}{l}58 \\
76 \\
26\end{array}$ & $\begin{array}{l}50 \\
03 \\
20\end{array}$ & $\begin{array}{r}4 \\
72 \\
57\end{array}$ & $\begin{array}{l}25 \\
25 \\
28\end{array}$ & & $\begin{array}{l}27 \\
34 \\
36\end{array}$ \\
\hline $\begin{array}{l}z \\
\theta \\
y\end{array}$ & $\begin{array}{l}\overline{2} 63 \\
\overline{2} 95 \\
\overline{2} 96\end{array}$ & 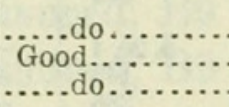 & $\begin{array}{l}28 \\
18 \\
19\end{array}$ & $\begin{array}{l}26 \\
54 \\
14\end{array}$ & $\begin{array}{l}70 \\
67 \\
64\end{array}$ & $\begin{array}{l}35 \\
00 \\
43\end{array}$ & $\begin{array}{l}27 \\
19 \\
19\end{array}$ & $\begin{array}{l}37 \\
15 \\
14\end{array}$ & & $\begin{array}{l}45 \\
29 \\
34\end{array}$ \\
\hline $\begin{array}{c}\dot{\rho} \\
x_{1} \\
6\end{array}$ & $\begin{array}{r}5.10 .5 \\
\frac{3}{3} 42 \\
343\end{array}$ & $\begin{array}{l}\text { Very poor. } \\
\text { Very good. } \\
\text { Poor ....... }\end{array}$ & $\begin{array}{l}18 \\
49 \\
49\end{array}$ & $\begin{array}{l}41 \\
04 \\
36\end{array}$ & $\begin{array}{l}69 \\
75 \\
70\end{array}$ & $\begin{array}{l}41 \\
41 \\
29\end{array}$ & $\begin{array}{l}17 \\
49 \\
49\end{array}$ & $\begin{array}{l}24 \\
45 \\
45\end{array}$ & $\begin{array}{l}69 \\
75 \\
69\end{array}$ & $\begin{array}{l}24 \\
41 \\
03\end{array}$ \\
\hline $\begin{array}{l}r \\
e^{\prime} \\
f_{1}\end{array}$ & $\begin{array}{l}351 \\
3553 \\
361\end{array}$ & 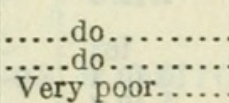 & $\begin{array}{l}42 \\
44 \\
39\end{array}$ & $\begin{array}{l}32 \\
20 \\
25\end{array}$ & & $\begin{array}{l}45 \\
59 \\
48\end{array}$ & & $\begin{array}{l}17 \\
23 \\
15\end{array}$ & & $\begin{array}{l}26 \\
58 \\
06\end{array}$ \\
\hline $\begin{array}{l}g_{1} \\
h_{1} \\
i_{1}\end{array}$ & $\begin{array}{r}\overline{3} 62 \\
3.10 .20 \\
. \overline{4} 61\end{array}$ & $\begin{array}{l}\text { Fair......... } \\
\text { Ver..do.... }\end{array}$ & $\begin{array}{l}37 \\
25 \\
48\end{array}$ & $\begin{array}{l}55 \\
03 \\
06\end{array}$ & & $\begin{array}{l}35 \\
54 \\
55\end{array}$ & $\begin{array}{l}38 \\
25 \\
46\end{array}$ & $\begin{array}{l}13 \\
30 \\
26\end{array}$ & & $\begin{array}{l}19 \\
02 \\
49\end{array}$ \\
\hline $\begin{array}{l}j_{1} \\
k_{1} \\
l_{1}\end{array}$ & $\begin{array}{l}\text { 3. } 6.30 \\
794 \\
9.16 .2\end{array}$ & $\begin{array}{l}\text { Poor ....... } \\
\text { Very poor. } \\
\text { Poor....... }\end{array}$ & $\begin{array}{l}51 \\
50 \\
41\end{array}$ & $\begin{array}{l}47 \\
11 \\
25\end{array}$ & $\begin{array}{l}22 \\
77 \\
85\end{array}$ & $\begin{array}{l}23 \\
12 \\
47\end{array}$ & $\begin{array}{l}52 \\
50 \\
41\end{array}$ & $\begin{array}{l}31 \\
46 \\
33\end{array}$ & $\begin{array}{l}22 \\
77 \\
85\end{array}$ & $\begin{array}{l}35 \\
29 \\
46\end{array}$ \\
\hline$m_{1}$ & 12. 25.1 & Good..... & 36 & 52 & 88 & 22 & 37 & 07 & 88 & 27 \\
\hline
\end{tabular}


Table 6.-Datolite.

A table giving the new forms observed on datolite from Westfield, Mass., during the present investigation, together with the calculated angles for these forms in the Goldschmidt orientation.

\begin{tabular}{|c|c|c|c|c|c|c|}
\hline Letter. & Miller. & Symbol. & $\phi$ & & $\rho$ & \\
\hline $\begin{array}{l}\mathfrak{c} \\
\Im \\
\&\end{array}$ & $\begin{array}{l}083 \\
380 \\
504\end{array}$ & $\begin{array}{r}0 \frac{8}{3} \\
\infty \\
+\quad \frac{8}{3} \\
+\quad 0\end{array}$ & $\begin{array}{r}\circ \\
0 \\
58 \\
90\end{array}$ & $\begin{array}{l}\text { ' } \\
05 \\
42 \\
00\end{array}$ & $\begin{array}{c}\circ \\
59 \\
90 \\
51\end{array}$ & $\begin{array}{l}\prime \\
25 \\
00 \\
28\end{array}$ \\
\hline $\begin{array}{l}\text { Vic. } \\
\mathfrak{M} \\
\text { Vic. }\end{array}$ & $\begin{array}{r}39.0 .32 \\
302 \\
25.0 .24\end{array}$ & $\begin{array}{rl}+\frac{39}{32} & 0 \\
+\quad 3 & 0 \\
+\frac{3}{2} & 0\end{array}$ & $\begin{array}{l}90 \\
90 \\
90\end{array}$ & $\begin{array}{l}00 \\
00 \\
00\end{array}$ & $\begin{array}{l}50 \\
56 \\
46\end{array}$ & $\begin{array}{l}45 \\
25 \\
14\end{array}$ \\
\hline $\begin{array}{l}\mathfrak{D} \\
\mathfrak{B} \\
\mathfrak{Q}\end{array}$ & $\begin{array}{r}231 \\
191 \\
1.10 .1\end{array}$ & $\begin{array}{r}+23 \\
+19 \\
+110\end{array}$ & $\begin{array}{r}46 \\
9 \\
9\end{array}$ & $\begin{array}{l}31 \\
59 \\
00\end{array}$ & $\begin{array}{l}70 \\
80 \\
81\end{array}$ & $\begin{array}{l}08 \\
13 \\
09\end{array}$ \\
\hline$\underset{\mathfrak{T}}{\mathfrak{T}}$ & $\begin{array}{r}1.12 .1 \\
166 \\
385\end{array}$ & $\begin{array}{rr}+112 \\
+\quad \frac{1}{6} \\
+\frac{1}{3}\end{array}$ & $\begin{array}{r}7 \\
14 \\
30\end{array}$ & $\begin{array}{l}31 \\
58 \\
47\end{array}$ & $\begin{array}{l}82 \\
75 \\
44\end{array}$ & $\begin{array}{l}35 \\
36 \\
33\end{array}$ \\
\hline $\begin{array}{l}\mathfrak{U} \\
\mathfrak{B} \\
\mathfrak{W}\end{array}$ & $\begin{array}{l}213 \\
586 \\
183\end{array}$ & $\begin{array}{r}+\frac{2}{3} \\
+\frac{4}{3} \\
+\frac{5}{6} \\
+\frac{4}{3} \\
+\frac{1}{3} \frac{8}{3}\end{array}$ & $\begin{array}{l}38 \\
44 \\
11\end{array}$ & $\begin{array}{l}26 \\
44 \\
15\end{array}$ & $\begin{array}{l}47 \\
49 \\
59\end{array}$ & $\begin{array}{l}12 \\
59 \\
55\end{array}$ \\
\hline $\begin{array}{l}\mathfrak{x} \\
\mathfrak{2} \\
3\end{array}$ & $\begin{array}{r}5.10 .8 \\
1.15 .6 \\
367\end{array}$ & $\begin{aligned} &+ \frac{5}{8} \\
&+\frac{3}{3} \\
&+\frac{1}{6} \\
&+\frac{3}{7} \\
&+\frac{6}{7}\end{aligned}$ & $\begin{array}{r}38 \\
6 \\
38\end{array}$ & $\begin{array}{l}26 \\
07 \\
29\end{array}$ & $\begin{array}{l}45 \\
57 \\
34\end{array}$ & $\begin{array}{l}21 \\
53 \\
47\end{array}$ \\
\hline $\begin{array}{l}\mathfrak{b} \\
\mathfrak{i} \\
\mathfrak{i}\end{array}$ & $\begin{array}{r}467 \\
5.11 .11 \\
\overline{1} 41\end{array}$ & $\begin{array}{rr}+4 & 8 \\
+57 \\
+11 \\
-11 & 1\end{array}$ & $\begin{array}{l}46 \\
35 \\
21\end{array}$ & $\begin{array}{l}37 \\
50 \\
30\end{array}$ & $\begin{array}{l}38 \\
38 \\
69\end{array}$ & $\begin{array}{l}22 \\
03 \\
52\end{array}$ \\
\hline $\begin{array}{l}\mathrm{f} \\
\mathrm{l} \\
\mathrm{m}\end{array}$ & $\begin{array}{r}\overline{3} 82 \\
7.12 .2 \\
\overline{6} 61\end{array}$ & $\begin{array}{ll}-\frac{3}{2} & 4 \\
-\frac{7}{2} & 6 \\
-6 & \end{array}$ & $\begin{array}{l}30 \\
42 \\
57\end{array}$ & $\begin{array}{l}36 \\
39 \\
39\end{array}$ & $\begin{array}{l}71 \\
79 \\
82\end{array}$ & $\begin{array}{l}16 \\
04 \\
00\end{array}$ \\
\hline $\begin{array}{l}0 \\
\mathfrak{b} \\
8\end{array}$ & $\begin{array}{r}761 \\
\overline{15} .10 .1 \\
\overline{5} .12 .1\end{array}$ & $\begin{array}{rr}-7 & 6 \\
-1510 \\
-512\end{array}$ & $\begin{array}{l}61 \\
67 \\
33\end{array}$ & $\begin{array}{l}31 \\
04 \\
21\end{array}$ & $\begin{array}{l}82 \\
86 \\
83\end{array}$ & $\begin{array}{l}52 \\
30 \\
44\end{array}$ \\
\hline $\begin{array}{l}\mathrm{t} \\
\mathrm{u} \\
\mathrm{r}\end{array}$ & $\begin{array}{r}\overline{15 .} 40.2 \\
\overline{1} 24 \\
\overline{9} 44\end{array}$ & 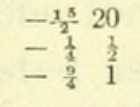 & $\begin{array}{l}80 \\
38 \\
74\end{array}$ & $\begin{array}{l}25 \\
01 \\
17\end{array}$ & $\begin{array}{l}82 \\
21 \\
66\end{array}$ & $\begin{array}{l}31 \\
56 \\
53\end{array}$ \\
\hline $\begin{array}{l}\boldsymbol{z} \\
\theta \\
8\end{array}$ & $\begin{array}{r}\overline{3} .12 .4 \\
\overline{5} .18 .4 \\
\overline{3} 92\end{array}$ & $\begin{array}{ll}-\frac{3}{4} & 3 \\
-\frac{8}{4} & \frac{9}{2} \\
-\frac{3}{2} & \frac{9}{2}\end{array}$ & $\begin{array}{l}21 \\
23 \\
27\end{array}$ & $\begin{array}{l}29 \\
39 \\
44\end{array}$ & $\begin{array}{l}63 \\
72 \\
72\end{array}$ & $\begin{array}{l}57 \\
13 \\
47\end{array}$ \\
\hline $\begin{array}{l}\dot{\rho} \\
x_{1} \\
\sigma\end{array}$ & $\begin{array}{r}\text { 3. } 20.4 \\
\overline{1} 43 \\
386\end{array}$ & $\begin{array}{ll}-\frac{5}{4} & 5 \\
-\frac{1}{3} & \frac{4}{3} \\
-\frac{1}{2} & \frac{4}{3}\end{array}$ & $\begin{array}{l}21 \\
21 \\
30\end{array}$ & $\begin{array}{l}31 \\
25 \\
32\end{array}$ & $\begin{array}{l}73 \\
42 \\
44\end{array}$ & $\begin{array}{l}39 \\
15 \\
28\end{array}$ \\
\hline $\begin{array}{l}\Upsilon \\
e_{1} \\
f_{1}\end{array}$ & $\begin{array}{l}1.10 .6 \\
3.10 .9 \\
1.12 .6\end{array}$ & $\begin{array}{l}-\frac{1}{6} \frac{8}{3} \\
=\frac{1}{3} \frac{10}{9} \\
-\frac{1}{8} \\
\frac{1}{2}\end{array}$ & $\begin{array}{r}8 \\
25 \\
7\end{array}$ & $\begin{array}{l}50 \\
12 \\
23\end{array}$ & $\begin{array}{l}46 \\
37 \\
52\end{array}$ & $\begin{array}{l}58 \\
55 \\
00\end{array}$ \\
\hline $\begin{array}{l}g_{1} \\
h_{1} \\
i_{1}\end{array}$ & $\begin{array}{r}\overline{1} 63 \\
\overline{10} .10 .3 \\
\overline{1} .12 .8\end{array}$ & $\begin{array}{l}-\frac{1}{3} 2 \\
-\frac{10}{3} \\
-\frac{1}{8} \frac{3}{2}\end{array}$ & $\begin{array}{r}14 \\
57 \\
7\end{array}$ & $\begin{array}{l}39 \\
39 \\
21\end{array}$ & $\begin{array}{l}37 \\
75 \\
43\end{array}$ & $\begin{array}{l}55 \\
48 \\
48\end{array}$ \\
\hline $\begin{array}{l}j_{1} \\
k_{1} \\
l_{1}\end{array}$ & $\begin{array}{l}\overline{1} 5.6 .5 \\
297 \\
\overline{1} .16 .9\end{array}$ & $\begin{array}{l}-3 \frac{6}{6} \\
-\frac{3}{7} \\
-\frac{1}{8} \\
-\frac{1}{8}\end{array}$ & $\begin{array}{r}75 \\
19 \\
5\end{array}$ & $\begin{array}{l}59 \\
11 \\
31\end{array}$ & $\begin{array}{r}72 \\
40 \\
6\end{array}$ & $\begin{array}{l}21 \\
49 \\
28\end{array}$ \\
\hline$m_{1}$ & 1.50 .24 & $-\frac{1}{25} \frac{25}{12}$ & 1 & 42 & 7 & 30 \\
\hline
\end{tabular}




\section{COMBINATIONS.}

Below are listed the combinations recorded for 55 of the crystals measured, including all of those which showed new or rare forms. The greatest number of forms recorded for any crystal is 35 , while the least number given below is 5. The latter crystal was, however, very incompletely developed, and many of the others which showed fewest forms would have shown others had the crystal not been badly broken or much crowded during growth. Some of the crystals listed below were incompletely measured.

Combinations observed on datolite from Westfield.

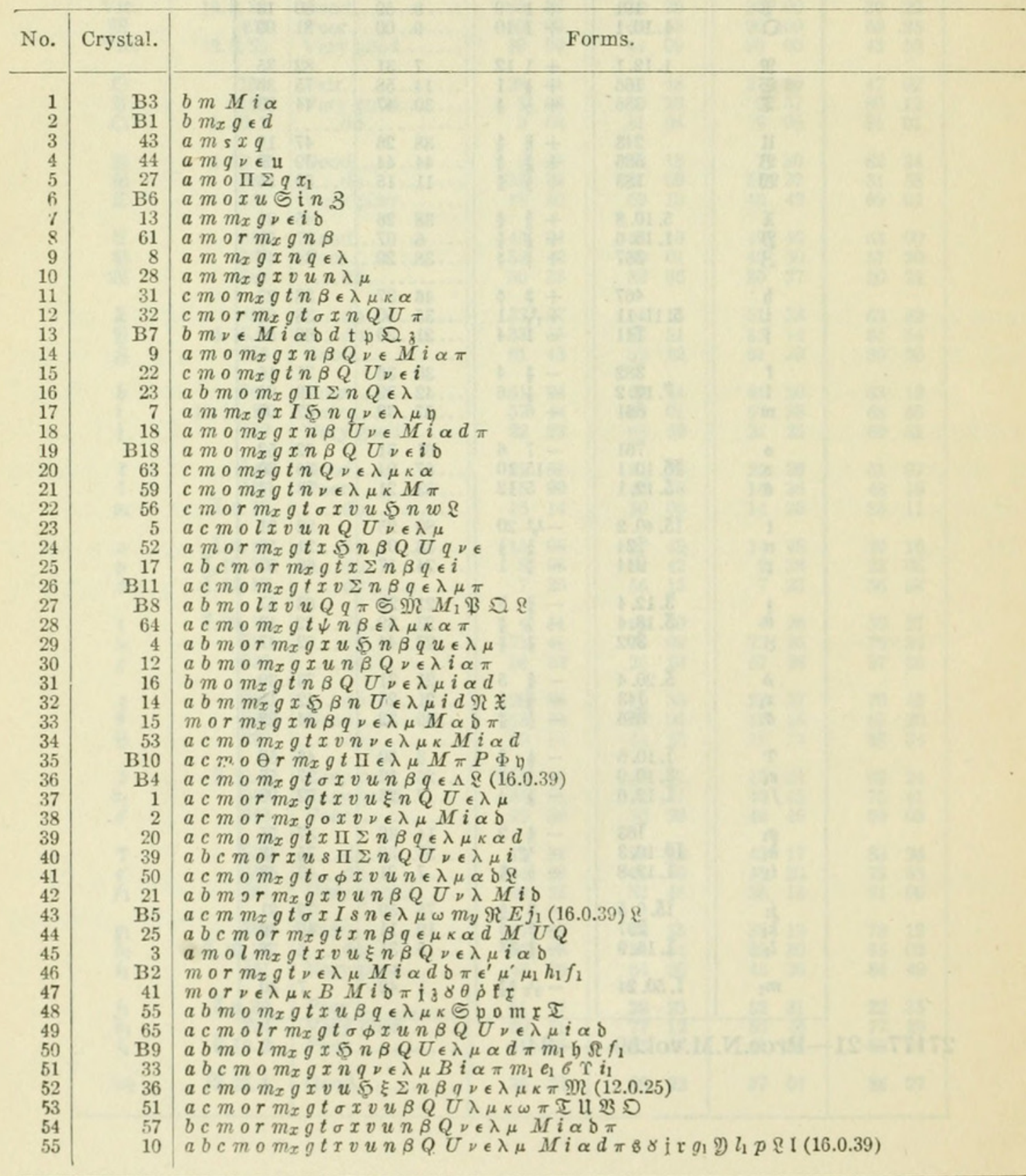


ZONES.

The several prominent zones present on datolite have been discussed by Görgey and Goldschmidt, using the Goldschmidt orientation. It is of interest here to compare some of the more prominent zones in the Dana orientation with the normal series according to the law of complication of Goldschmidt with the especial purpose of criticising the new forms here described for this mineral. The method is useful indeed in checking up the indices assigned to new forms. This is illustrated by the fact that, although preceding portions of this paper had been completed previous to the analysis of the zones, the indices of at least two forms listed as new were shown by this method to be incorrect. These two have been corrected. The zones discussed are those shown on the gnomonic projection, plate 1 of this paper. The excellent work of Schaller ${ }^{5}$ has been a most useful guide in this interpretation.

Zone No. 1.-Prism zone.

Symbol $\frac{h}{k}$.

\begin{tabular}{l|c|c|c|c|c|c|c|c|c|c|c|c|c}
\hline Form............... & $b$ & $\theta$ & $l$ & 5 & $o$ & $r$ & $N$ & $m$ & $e$ & $s$ & $\Delta$ & $\eta$ & $a$ \\
Symbol.............. & 0 & 140 & 130 & 380 & 120 & 230 & {$[340] a$} & 110 & {$[320]$} & 530 & {$[210]$} & {$[410]$} & 100 \\
N $\ldots$ & $1 / 3$ & $3 / 8$ & $1 / 2$ & $2 / 3$ & $3 / 4$ & 1 & $3 / 2$ & $5 / 3$ & 2 & 4 & $\infty$ \\
\hline
\end{tabular}

$a$ Forms bracketed are known for the species but were not observed during the present study and are not shown on the gnomonic projection.

This zone is normal with one form extra and four missing. The extra form is the one here listed as new, 380. In place of this the normal series requires the form $2 / 5$, or 250 . The form 380 is considered to be well founded, however, by its clean-cut face and sharp signal. That this is not 250 is shown by the following comparison of angles:

$$
\left.\begin{array}{l}
250 \varphi=32^{\circ} 13^{\prime} \\
380 \varphi=30^{\circ} 35^{\prime}
\end{array}\right\} \text { Measured } \varphi=30^{\circ} 05^{\prime} .
$$

Zone No. 2.-Clinodome zone.

Symbol $\frac{k}{l}$.

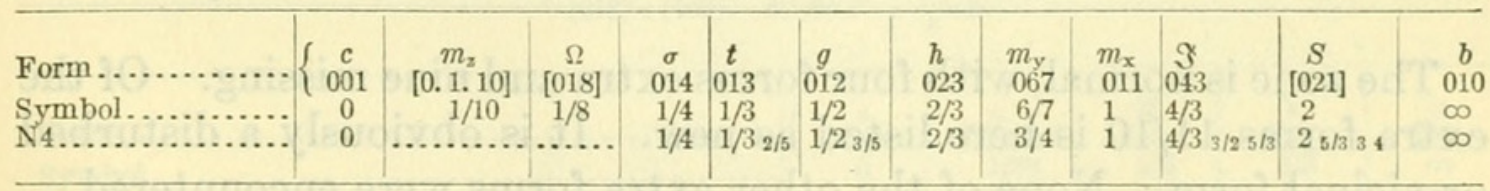

This zone is normal, with eight forms missing and three extra. Of the extra forms $(1 / 10)$ and (1/8) were not observed by the writer, although 018 is reported from this locality by Whitlock. (067)

\footnotetext{
5 Schaller, W. T., Mercury Minerals of Terlingua, Texas. U. S. Geol. Survey Bull. 405, 1959.
} 
described by Kraus and Cook was doubtfully confirmed by one face measured on a single crystal. The only form listed here as new in this zone is $4 / 3$, or 043 , which fits in the normal series.

\section{Zone No. 3.-Positive orthodome zone.}

$(001):(100)$. Symbol $\frac{h}{l}$.

\begin{tabular}{|c|c|c|c|c|c|c|c|c|c|c|c|c|c|c|}
\hline $\begin{array}{l}\text { Form.... } \\
\text { Symbol. } \\
N_{1} \ldots \ldots \ldots\end{array}$ & $\left\{\begin{array}{c}c \\
001 \\
0 \\
0\end{array}\right.$ & $\begin{array}{c}p \\
106 \\
1 / 6 \\
\ldots\end{array}$ & $\begin{array}{c}u \\
104 \\
1 / 4 \\
1 / 4\end{array}$ & $\begin{array}{c}v \\
103 \\
1 / 3 \\
1 / 3\end{array}$ & $\begin{array}{c}5 \\
308 \\
3 / 8\end{array}$ & $\begin{array}{c}\mathbb{R} \\
205 \\
2 / 5 \\
2 / 5\end{array}$ & $\begin{array}{l}\text { vic. } \\
12.0 .25 \\
12 / 25\end{array}$ & $\begin{array}{l}x \\
102 \\
1 / 2 \\
1 / 2 z_{3} / 5\end{array}$ & $\begin{array}{c}I \\
203 \\
2 / 3 \\
2 / 3\end{array}$ & $\begin{array}{c}f \\
304 \\
3 / 4 \\
3 / 4\end{array}$ & $\begin{array}{c}\phi \\
101 \\
1 \\
1\end{array}$ & $\begin{array}{l}\mathfrak{M} \\
403 \\
4 / 3 \\
4 / 3\end{array}$ & $\begin{array}{l}\boldsymbol{s} \\
302 \\
3 / 2 \\
3 / 25 / 325 / 234\end{array}$ & $\begin{array}{l}a \\
10 \\
\alpha \\
\alpha\end{array}$ \\
\hline
\end{tabular}

This zone is then normal, with three forms extra and six forms missing. Of the extra forms (106), listed in Goldschmidt's Winkeltabellen, was observed as one narrow and etched face. The form 308, first described by Görgey and Goldschmidt from this locality, was many times confirmed and is well established. (12.0.25), admittedly vicinal, may be ignored. The new form (403) in this zone is normal, and being entirely probable may be regarded as established, although it was seen as only a single narrow face.

Zone No. 3b.-Negative orthodome zone.

(001) : (100) Symbol $\frac{-h}{l}$.

\begin{tabular}{|c|c|c|c|c|c|c|c|c|c|c|}
\hline $\begin{array}{l}\text { Form ..... } \\
\text { Symbol... } \mathrm{N}_{1} \ldots \ldots .\end{array}$ & $\left\{\begin{array}{r}c \\
001 \\
0 \\
0\end{array}\right.$ & 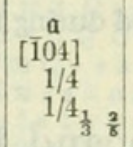 & $\begin{array}{c}\xi \\
102 \\
1 / 2 \\
1 / 2\end{array}$ & 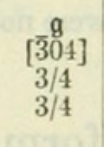 & $\begin{array}{c}\text { II } \\
\overline{1} 01 \\
1 \\
1_{\frac{4}{3}}\end{array}$ & $\begin{array}{l}\mathbf{Z} \\
\overline{3} 02 \\
3 / 2 \\
3 / 2_{8} \\
\mathbf{3}\end{array}$ & $\begin{array}{c}z \\
{\left[\begin{array}{c}201 \\
2 \\
2 \frac{8}{2}\end{array}\right.}\end{array}$ & $\begin{array}{c}{[702]} \\
7 / 2 \\
34\end{array}$ & {$\left[\begin{array}{c}{[11.0 .2} \\
11 / 2\end{array}\right]$} & $\begin{array}{c}a \\
100 \\
\infty \\
\infty\end{array}$ \\
\hline
\end{tabular}

The zone is normal, with nine forms missing and two extra. Of the extra forms neither was found by the writer nor were any new forms listed by the writer in this zone.

Zone No. 4a.-Positive pyramid zone.

(001) : (110) Symbol $\frac{h}{l}$.

\begin{tabular}{|c|c|c|c|c|c|c|c|c|c|c|c|c|}
\hline $\begin{array}{l}\text { Form... } \\
\text { Symbol. } \\
N_{1} \ldots \ldots\end{array}$ & $\left\{\begin{array}{c}c \\
001 \\
0 \\
0\end{array}\right.$ & $\begin{array}{l}{[1.1 .18]} \\
(1 / 18)\end{array}$ & $\begin{array}{c}Z \\
{[116]} \\
(1,6)\end{array}$ & {$\left[\begin{array}{c}f \\
{\left[\frac{1}{8}\right)}\end{array}\right.$} & $\begin{array}{l}W \\
{[114]} \\
1 / 4 \\
1 / 4\end{array}$ & $\begin{array}{c}L \\
{[113]} \\
1 / 3 \\
1 / 3 \frac{2}{6}\end{array}$ & $\begin{array}{l}\Lambda \\
112 \\
1 / 2 \\
1 / 2\end{array}$ & 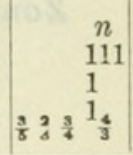 & 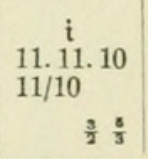 & $\begin{array}{c}\delta \\
{[221]} \\
2 \\
2 \\
\frac{8}{5}\end{array}$ & $\begin{array}{c}5 \\
331 \\
3 \\
3 \\
4\end{array}$ & $\begin{array}{l}m \\
110 \\
\infty \\
\infty\end{array}$ \\
\hline
\end{tabular}

The zone is normal, with four forms extra and nine missing. Of the extra forms $11 / 10$ is here listed as new. It is obviously a disturbed or vicinal form. None of the other extra forms were encountered. 
Zone No. 4b.-Negative pyramid zone.

(001) : (1110) Symbol $\frac{-h}{l}$.

\begin{tabular}{|c|c|c|c|c|c|c|c|c|c|c|c|c|}
\hline $\begin{array}{l}\text { Form........... } \\
\text { Symbol } \ldots \ldots \ldots \ldots \\
2 \mathrm{v} \ldots \ldots \ldots \ldots \ldots \ldots \\
\mathrm{N}_{1} \ldots \ldots \ldots \ldots \ldots \ldots\end{array}$ & $\left\{\begin{array}{c}c \\
001 \\
0 \\
0 \\
0 \\
0 \frac{1}{4}\end{array}\right.$ & $\begin{array}{l}\omega \\
\bar{\tau} 116 \\
1 / 6 \\
1 / 3 \\
1 / 3\end{array}$ & $\begin{array}{l}\pi \\
115 \\
1 / 5 \\
2 / 5 \\
2 / 5\end{array}$ & $\begin{array}{c}8 \\
229 \\
2 / 9 \\
4 / 9 \\
\cdots \cdots\end{array}$ & $\begin{array}{l}\mu \\
114 \\
1 / 4 \\
1 / 2 \\
1 / 2\end{array}$ & $\begin{array}{c}\mu_{1} \\
227 \\
2 / 7 \\
4 / 7\end{array}$ & $\begin{array}{l}\lambda \\
113 \\
1 / 3 \\
2 / 3 \\
2 / 3\end{array}$ & $\begin{array}{l}\epsilon \\
\overline{1} 12 \\
1 / 2 \\
1 \\
1_{\frac{3}{4}}\end{array}$ & $\begin{array}{l}b \\
223 \\
2 / 3 \\
4 / 3 \\
4 / 3\end{array}$ & $\begin{array}{c}1 \\
111 \\
1 \\
2 \\
\frac{8}{3} \\
\frac{2}{2}\end{array}$ & $\begin{array}{l}P \\
\overline{3} 32 \\
3 / 2 \\
3 \\
34\end{array}$ & $\begin{array}{l}m \\
110 \\
\infty \\
\infty \\
\infty\end{array}$ \\
\hline
\end{tabular}

The zone is normal, with six forms missing and two extra. Of the extra forms ( 227$)$, previously reported, was confirmed by one narrow and poor face while $(\overline{2} 29)$, here listed as new was found on two crystals. Both are probably established though disturbed forms.

Zone No. 5a.-Positive pyramid zone.

(011) : (100). Symbol $\frac{h}{l} \cdot \frac{k}{l}=1$.

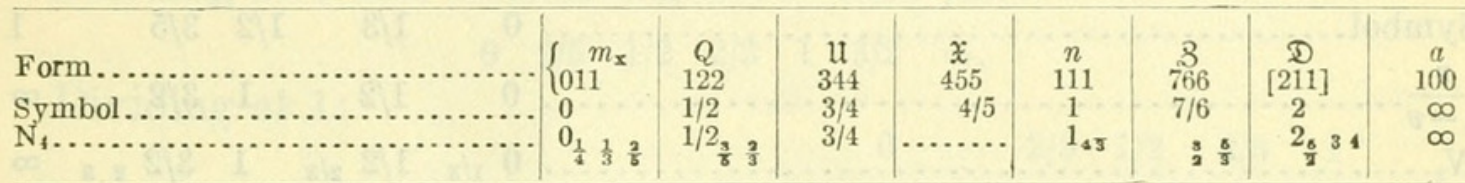

The zone is normal, though very incomplete. Two forms are extra, both of which are new. These are regarded as well founded through disturbed forms.

Zone No. 5b.-Negative pyramid zone.

(011) : (100). Symbol $\frac{-h}{l} \cdot \frac{k}{l}=1$.

\begin{tabular}{|c|c|c|c|c|c|c|}
\hline 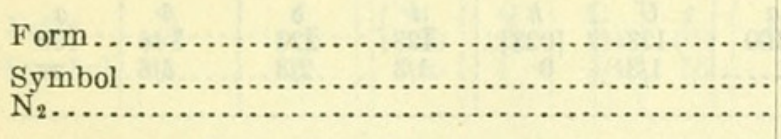 & $\left\{\begin{array}{c}m_{\mathbf{x}} \\
011 \\
0 \\
0\end{array}\right.$ & $\begin{array}{l}M \\
\overline{1} 22 \\
1 / 2 \\
1 / 2\end{array}$ & $\begin{array}{c}\overline{1} 11 \\
1 \\
1\end{array}$ & $\begin{array}{c}\mathrm{u} \\
\overline{2} 11 \\
2 \\
2\end{array}$ & $\begin{array}{c}\sqrt[n]{811} \\
8 \\
\cdots\end{array}$ & $\begin{array}{l}a \\
100 \\
\infty \\
\infty\end{array}$ \\
\hline
\end{tabular}

The zone is normal, with no forms lacking and only one extra. The extra form ( $\overline{8} 11)$ observed independently by Gorgey and Goldschmidt, Ungemach, and the present.writer, can be regarded as established.

Zone No. 6.-Negative pyramid zone.

$(013):(\overline{1} 00)$. Symbol $\frac{h}{l} \cdot \frac{l}{k}=3$.

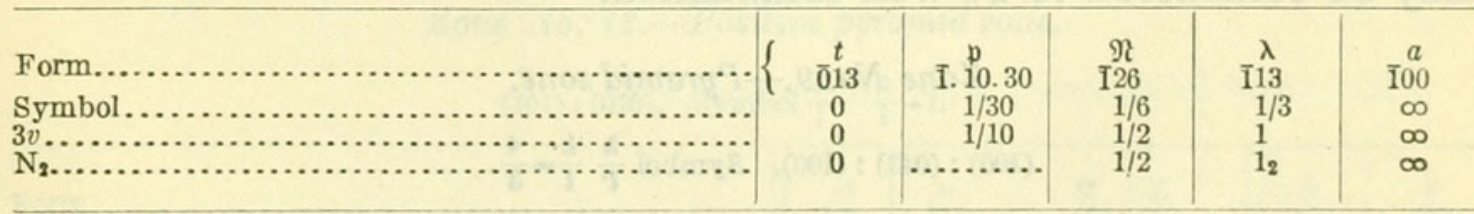

The zone is normal, having the form ( $\overline{1} .10 .30)$, here listed as new an extra form. 
Zone No. 7.-Pyramid zone.

$(100):(012):(\overline{1} 00)$. Symbol $\frac{h}{l} \cdot \frac{l}{k}=2$.

\begin{tabular}{|c|c|c|c|c|c|c|c|c|c|c|c|}
\hline $\begin{array}{l}\text { Form } \\
\text { Syml }\end{array}$ & $\left\{\begin{array}{c}a \\
100\end{array}\right.$ & $\begin{array}{c}q \\
312 \\
3 / 2\end{array}$ & $\begin{array}{l}w \\
324 \\
3 / 4\end{array}$ & $\begin{array}{l}\Lambda \\
112 \\
1 / 2\end{array}$ & $\begin{array}{l}g \\
012 \\
0\end{array}$ & $\begin{array}{l}\mathrm{m} \\
1.6 .12 \\
1 / 12\end{array}$ & $\begin{array}{l}\epsilon^{\prime} \\
\overline{1} 48 \\
1 / 8\end{array}$ & $\begin{array}{l}\quad h_{1} \\
\overline{3} \cdot 10.20 \\
3 / 20\end{array}$ & $\begin{array}{c}\alpha \\
124 \\
1 / 4\end{array}$ & $\begin{array}{c}\epsilon \\
\overline{1} 12 \\
1 / 2\end{array}$ & $\begin{array}{l}\frac{a}{100} \\
\infty\end{array}$ \\
\hline
\end{tabular}

Dividing at 0 and reversing the first part gives:

Symbol............................... $0 \quad 1 / 2 \quad 3 / 4 \quad 3 / 2 \quad \infty$

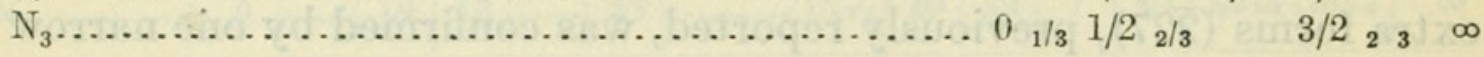

The first or positive portion of the zone is thus normal, with four forms missing but none extra. The second portion gives:

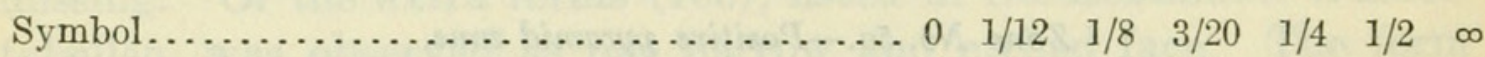

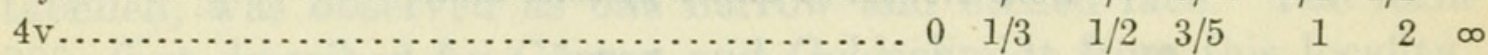

Dividing at 1 :

Symbol................................... $0 \quad 1 / 3 \quad 1 / 2 \quad 3 / 5 \quad 1$

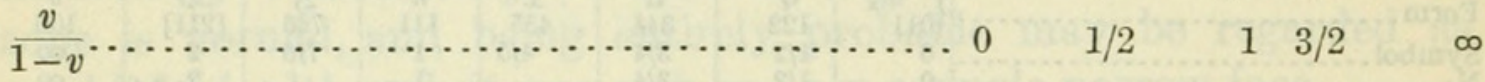

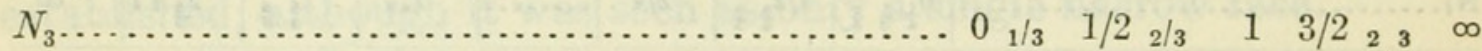

The zone is then normal with no extra forms. This is especially gratifying, since new forms with high indices, such as $\overline{1}-6-12$ and $\overline{3} .10 .20$, fit in very well.

Zone No. 8.-Pyramid zone.

$(100):(023):(\overline{1} 00)$. Symbol $\frac{h}{l} \frac{k}{l}=\frac{2}{3}$.

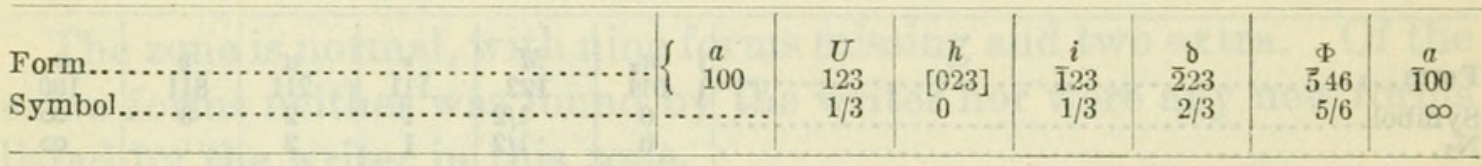

Dividing at 0 and considering the last part:

Symbol............................................. $1 / 3 \quad 3 / 3 \quad 5 / 6 \quad \infty$

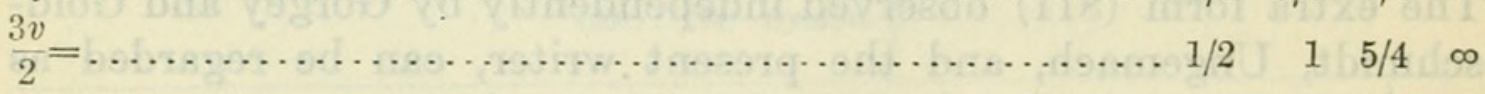

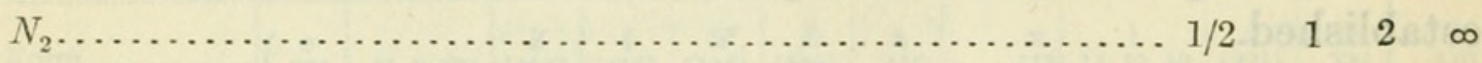

This zone is thus normal, with $5 / 4$ or $\overline{5} 46$ extra. This form, described by Ungemach and confirmed by the present investigation, may be considered to be well established.

Zone No. 9.-Pyramid zone.

(100) : $(0+3):(\overline{100})$. Symbol $\frac{h}{l} \cdot \frac{k}{l}=\frac{4}{3}$.

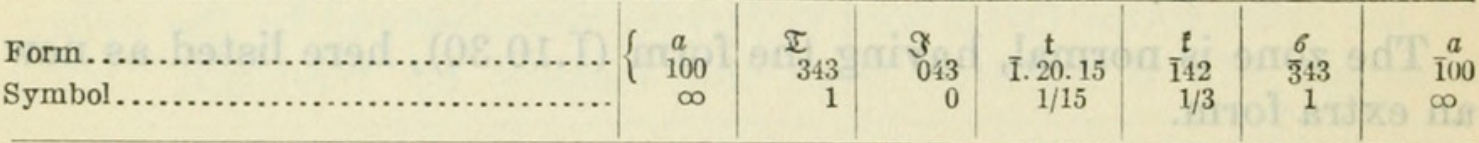


Dividing at 0 and considering the last part: $3 v$ $\begin{array}{lllll}0 & 1 / 15 & 1 / 3 & 1 & \infty\end{array}$

\section{Dividing at 1 :}

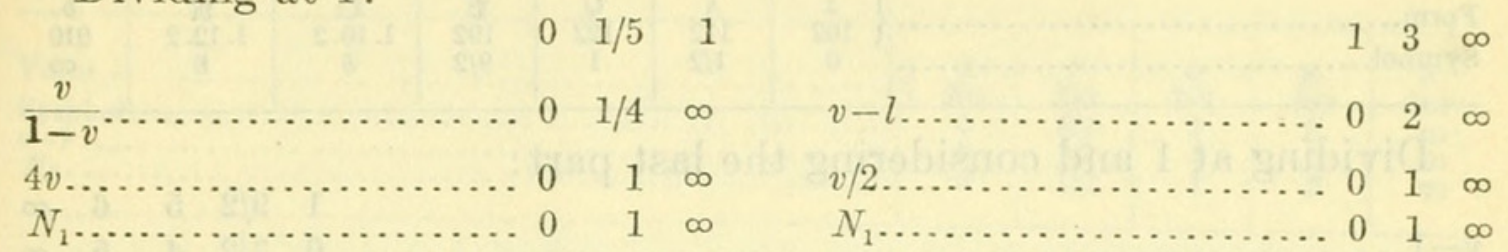

Zone No. 10.-Pyramid zone.

$(100):(021):(\overline{1} 00) . \quad$ Symbol $\frac{h}{l} \cdot \frac{k}{l}=2$.

\begin{tabular}{|c|c|c|c|c|c|c|c|c|c|}
\hline $\begin{array}{l}\text { Form. } \\
\text { Symbo }\end{array}$ & $\left\{\begin{array}{c}a \\
100\end{array}\right.$ & $\begin{array}{c}\beta \\
121 \\
1\end{array}$ & $\frac{S}{\left[\begin{array}{c}021 \\
0\end{array}\right]}$ & 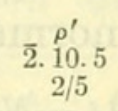 & $\begin{array}{c}\mathrm{i} \\
142 \\
1 / 2\end{array}$ & $\begin{array}{l}\overline{2}^{3} 63 \\
2 / 3\end{array}$ & $\begin{array}{c}B \\
\frac{1}{2} 21 \\
1\end{array}$ & $\begin{array}{l}x_{1} \\
342 \\
3 / 2\end{array}$ & $\begin{array}{c}a \\
\overline{100} \\
\infty\end{array}$ \\
\hline
\end{tabular}

Dividing at 0 and considering the second part:

Dividing at 1 :

$$
\begin{array}{lllllll}
0 & 2 / 5 & 1 / 2 & 2 / 3 & 1 & 3 / 2 & \infty
\end{array} .
$$

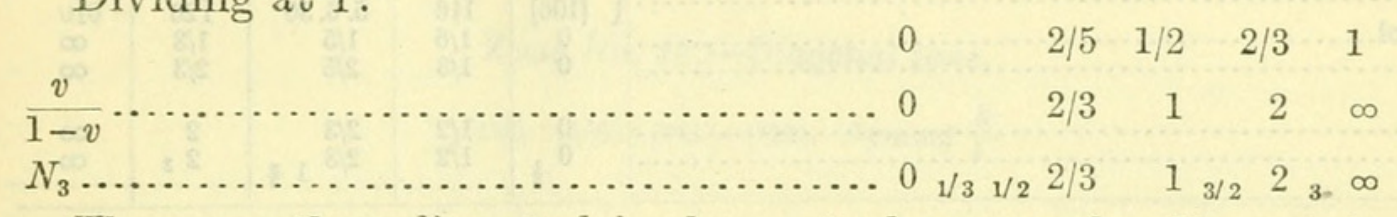

The zone thus dissected is shown to be normal. It contains the unusual new form $\overline{2} .10 .5$.

Zone No. 11.-Oblique pyramid zone.

(110) : (012): (110). Symbol $\frac{\mathrm{k}}{l}$.

\begin{tabular}{|c|c|c|c|c|c|c|c|c|c|c|c|}
\hline $\begin{array}{l}\text { Form } \\
\text { Symb }\end{array}$ & $\left\{\begin{array}{c}m \\
110 \\
\infty\end{array}\right.$ & $\begin{array}{c}Q \\
122 \\
1\end{array}$ & $\begin{array}{l}0 \\
134 \\
3 / 4\end{array}$ & $\begin{array}{l}g \\
012 \\
1 / 2\end{array}$ & $\begin{array}{c}0 \\
1.6 .14 \\
6 / 14\end{array}$ & $\begin{array}{l}\overline{1} . \mu^{\prime} \\
\frac{\mu^{\prime}}{2 / 5}\end{array}$ & $\begin{array}{l}E \\
\frac{E}{138} \\
3 / 8\end{array}$ & $\frac{\Re}{\frac{n}{1} 26}$ & $\begin{array}{l}\frac{\mu}{114} \\
1 / 4\end{array}$ & $\begin{array}{c}\epsilon \\
102 \\
0\end{array}$ & $\begin{array}{l}m \\
\overline{1} 10 \\
\infty\end{array}$ \\
\hline
\end{tabular}

Reversing:

$2 v$

$\begin{array}{lrrrrrrrrr}0 & 1 / 4 & 1 / 3 & 3 / 8 & 2 / 5 & 3 / 7 & 1 / 2 & 3 / 4 & 1 & \propto \\ 0 & 1 / 2 & 2 / 3 & 3 / 4 & 4 / 5 & 6 / 7 & 1 & 3 / 2 & 2 & \propto\end{array}$

Dividing at 1 :

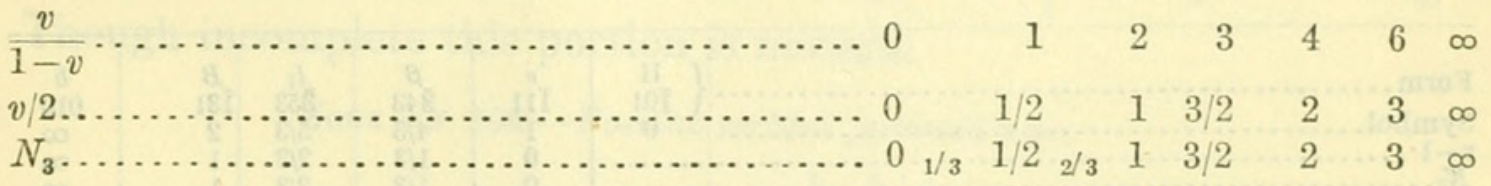

Zone No. 12.-Positive pyramid zone.

(101) : (010). Symbol $\frac{\mathrm{k}}{l} \cdot \frac{\mathrm{h}}{\mathrm{l}}=\mathrm{l}$.

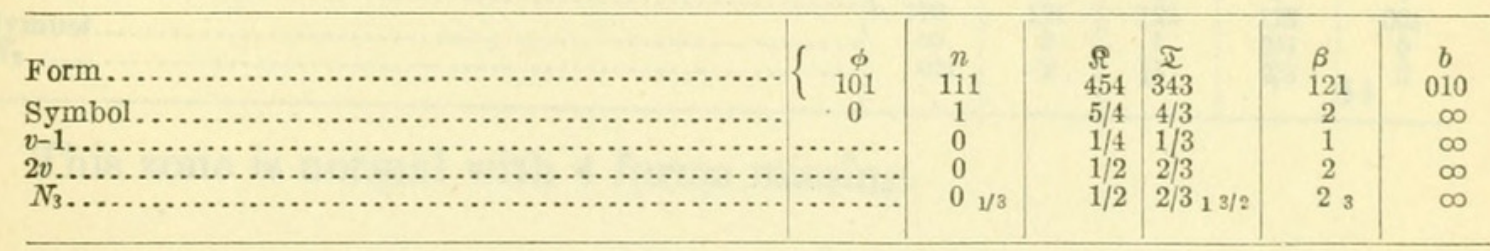

This zone, though incomplete, is normal with no extra forms. 
Zone No. 13.-Positive pyramid zone.

(010) : (102) : (010). Symbol $\frac{k}{l} \cdot \frac{l}{h}=2$.

Form...........................................
Symbol..................................

Dividing at 1 and considering the last part:

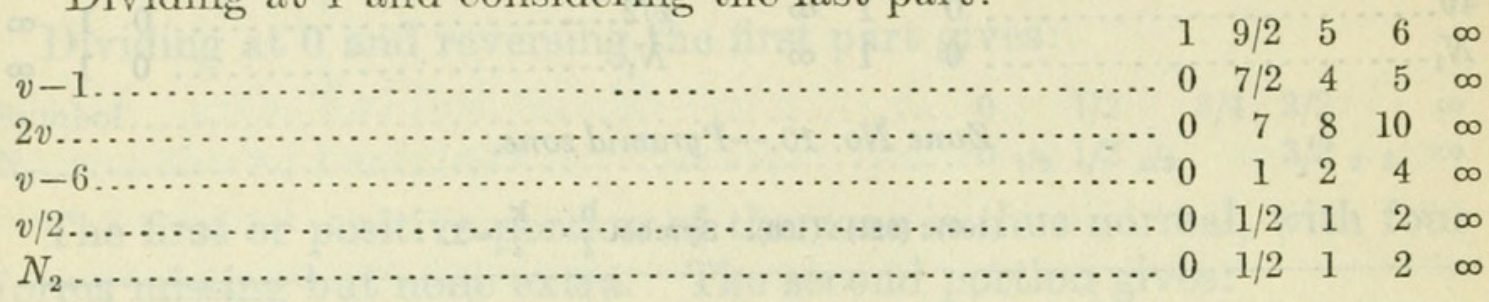

This zone is also entirely normal.

Zone No. 14.-Negative pyramid zone.

$(\overline{1} 06):(\overline{1} 16):(010)$. Symbol $\frac{k}{l} \cdot \frac{l}{h}=6$.

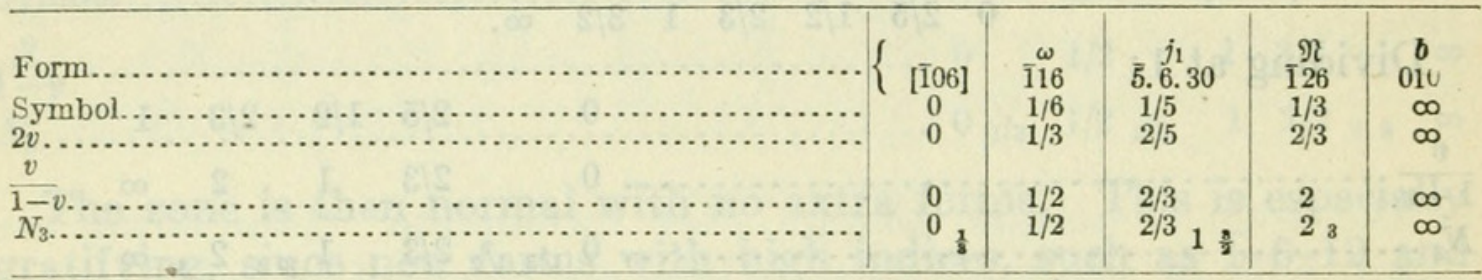

This zone is normal.

Zone No.15.-Negative pyramid zone. (010) : (102) : (010). Symbol $\frac{k}{l} \cdot \frac{l}{h}=2$.

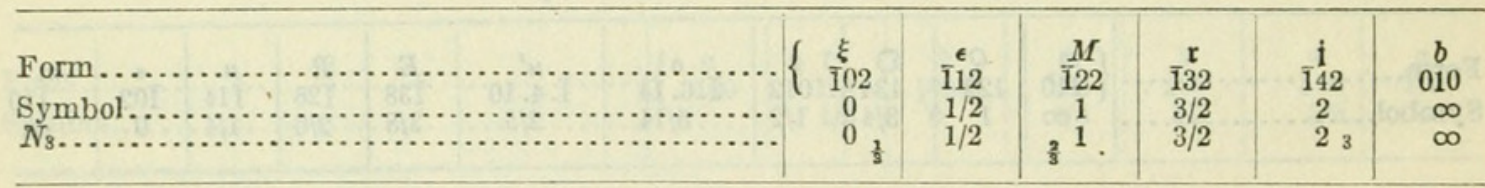

This zone though incomplete is entirely normal.

Zone No. 16.-Negative pyramid zone. (010) : (101) : (010). Symbol $\frac{k}{l} \cdot \frac{h}{l}=1$.

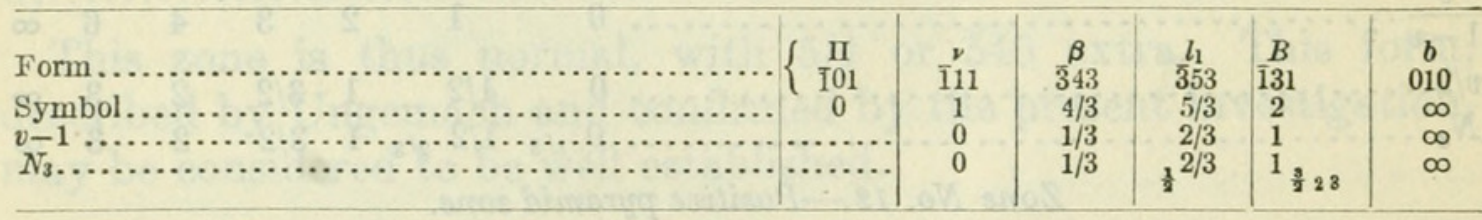

This zone is normal though incomplete. 
No. 2385. CRYSTALLOGRAPHIC STUDY OF DATOLITE-SHANNON. 537

Zone No. 17.-Negative pyramid zone.

$(010):(302):(010)$. Symbol $\frac{k}{l} \cdot \frac{h}{l}=\frac{3}{2}$.

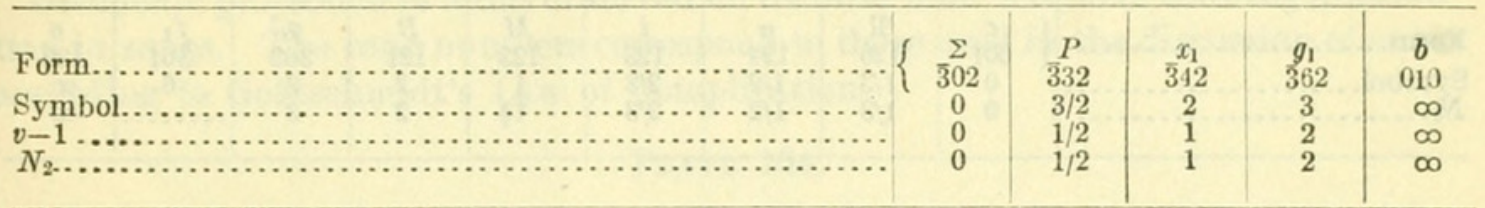

This zone is entirely normal and is complete.

Zone No. 18.-Diagonal zone.

$(110):(101):(011):(110)$. Symbol $\frac{k}{l}$.

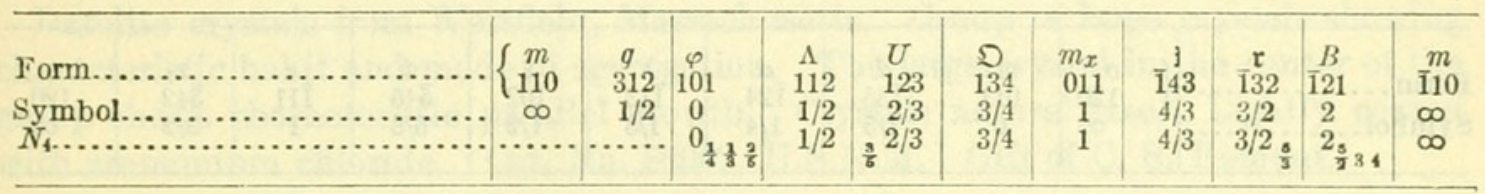

This zone though incomplete is normal.

Zone No. 19.-Diagonal zone.

$(120):(102):(011):(120)$. Symbol $\frac{h}{l}$.

\begin{tabular}{|c|c|c|c|c|c|c|c|c|c|c|}
\hline $\begin{array}{l}\text { Form... } \\
\text { Symbol. }\end{array}$ & $\left\{\begin{array}{c}\stackrel{0}{120} \\
\infty\end{array}\right.$ & $\begin{array}{c}n \\
111 \\
1\end{array}$ & $\begin{array}{c}\mathfrak{b} \\
768 \\
7 / 8\end{array}$ & $\begin{array}{l}w \\
324 \\
3 / 4\end{array}$ & $\begin{array}{l}x \\
102 \\
1 / 2\end{array}$ & $\begin{array}{r}m_{x} \\
011 \\
0\end{array}$ & 1. $\frac{\frac{8}{12}}{1 / 10} \cdot 10$ & $\frac{\vartheta}{\frac{\vartheta}{2} \overline{9} 5}$ & $\begin{array}{l}\overline{14} 2 \\
\overline{1} / 2\end{array}$ & $\begin{array}{r}\mathbf{1} 20 \\
\infty\end{array}$ \\
\hline
\end{tabular}

Dividing at 0 and reversing the first part:

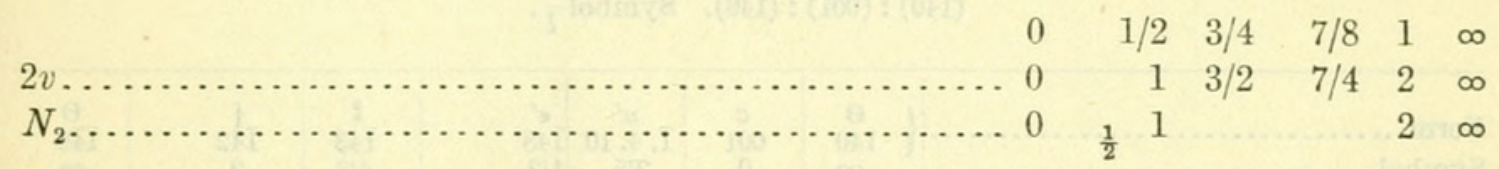

This zone is normal with 2 forms missing, and 1 form, 768, which is here listed as new, extra. The second part of the original zone is:

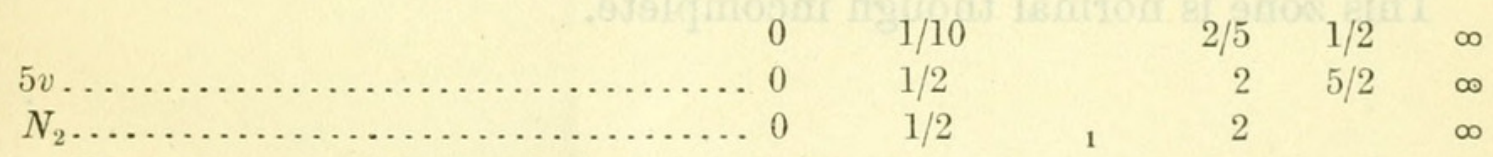

Though incomplete this portion is normal.

Zone No. 20a.-Positive vertical pyramid zone.

(001) $:(120)$. Symbol $\frac{k}{l} \cdot \frac{h}{k}=\frac{1}{2}$,

\begin{tabular}{|c|c|c|c|c|c|}
\hline 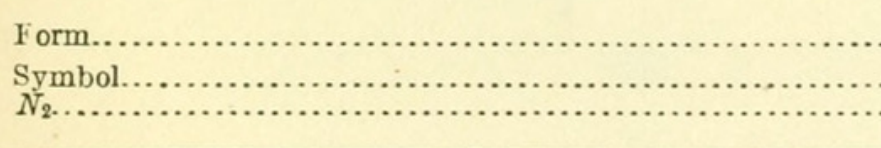 & $\left\{\begin{array}{c}O \\
120 \\
\infty \\
\infty \\
\infty\end{array}\right.$ & $\begin{array}{c}\beta \\
121 \\
2 \\
2\end{array}$ & $\begin{array}{c}Q \\
122 \\
1 \\
\pi_{0} 1\end{array}$ & $\begin{array}{c}U \\
123 \\
2 / 3 \\
2 / 3\end{array}$ & 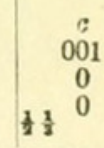 \\
\hline
\end{tabular}

This zone is normal with 4 forms missing. 
Zone No. 20 b.-Negative vertical pyramid zone. (001) : (120). Symbol $\frac{-k}{l}$.

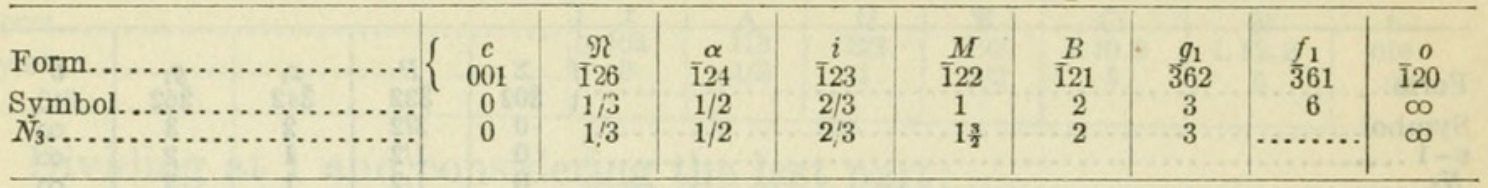

The zone is normal with only one form missing and one extra. The extra form is $\overline{3} 61$ which is here described as new.

Zone No. 22.-Diagonal zone.

$(120):(011):(\overline{1} 02):(\overline{1} \overline{2} 0)$. Symbol $\frac{h}{l}$.

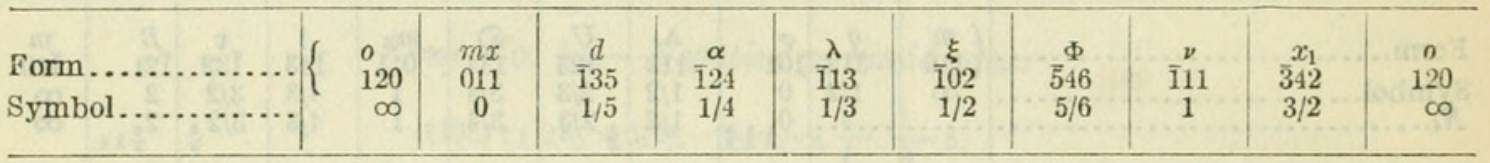

\section{Dividing at 1 :}

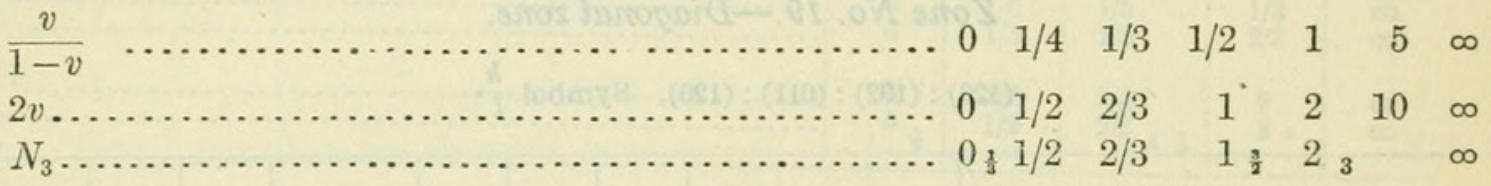

The zone is normal except for the form $\overline{5} 46$ which does not fit in.

Zone No. 23.-Vertical zone.

(140) : (001) : (140). Symbol $\frac{k}{l}$.

\begin{tabular}{|c|c|c|c|c|c|c|c|}
\hline 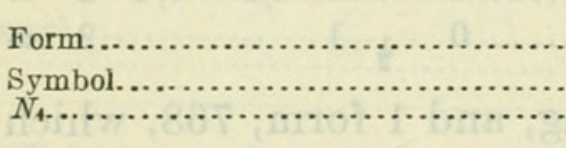 & $\left\{\begin{array}{c}\Theta \\
140 \\
\infty\end{array}\right.$ & $\begin{array}{c}c \\
001 \\
0 \\
0 \frac{1}{4} \frac{1}{3}\end{array}$ & $\begin{array}{l}\mu^{\prime} \\
1.4 .10 \\
2 / 5 \\
2 / 5\end{array}$ & $\begin{array}{l}\epsilon^{\prime} \\
\overline{1} 48 \\
1 / 2 \\
1 / 2: 2 \frac{2}{3} \div 1\end{array}$ & $\begin{array}{c}\mathfrak{\imath} \\
143 \\
4 / 3 \\
4 / 3\end{array}$ & $\begin{array}{ll} & i \\
142 \\
2 \\
\frac{5}{3}{ }^{2} \\
\frac{3}{2} 3 & 4\end{array}$ & $\begin{array}{r}\Theta \\
140 \\
\infty \\
\infty\end{array}$ \\
\hline
\end{tabular}

This zone is normal though incomplete. 


\section{EXPLANATION OF PLATES.}

Plate 103.

Gnomonic projection of forms observed on datolite from Westfield showing distribution in zones. The zone numbers correspond to those used in the discussion of zones according to Goldschmidt's Law of Complication.

\section{Plate 104.}

Datolite crystals from Westfield, Massachusetts. Large crystals showing type I habit with characteristic mutual interference surfaces and molds of anhydrite crystals. Crystals lightly coated with ammonium chloride. Natural size. Cat. No. 94253, U.S.N.M.

Plate 105.

Datolite crystals from Westfield, Massachusetts. Group of large crystals showing characteristic habit and mode of aggregation. The large crystal in the center of the group shows characteristic parallel growth. Crystals natural size. Lightly coated with ammonium chloride. Cat. No. 86002, U.S.N.M. Gift of C. S. Bement.

\section{Plate 106.}

Datolite crystals from Westfield, Massachusetts.

Upper. Group of crystals of Type 4 habit. The crystal figure 24 came from this group. Coated with ammonium chloride. $1 \frac{1}{2}$ times natural size.

Lower. Crystals lining cavity in vein of granular datolite. Coated with ammonium chloride. $1 \frac{1}{2}$ times natural size. 


\section{$2 \mathrm{BHL}$ Biodiversity Heritage Library}

Shannon, Earl V. 1921. "A crystallographic study of the datolite from Westfield, Massachusetts." Proceedings of the United States National Museum 59(2385), 479-539. https://doi.org/10.5479/si.00963801.59-2385.479.

View This Item Online: https://www.biodiversitylibrary.org/item/32485

DOI: https://doi.org/10.5479/si.00963801.59-2385.479

Permalink: https://www.biodiversitylibrary.org/partpdf/18493

\section{Holding Institution}

Smithsonian Libraries

\section{Sponsored by}

Smithsonian

\section{Copyright \& Reuse}

Copyright Status: NOT_IN_COPYRIGHT

This document was created from content at the Biodiversity Heritage Library, the world's largest open access digital library for biodiversity literature and archives. Visit BHL at https://www.biodiversitylibrary.org. 